\title{
WestVirginiaUniversity
}

THE RESEARCH REPOSITORY @ WVU

Graduate Theses, Dissertations, and Problem Reports

2004

\section{Channel geomorphology relationships for the Beaver Creek watershed}

\author{
Atif Hamid \\ West Virginia University
}

Follow this and additional works at: https://researchrepository.wvu.edu/etd

\section{Recommended Citation}

Hamid, Atif, "Channel geomorphology relationships for the Beaver Creek watershed" (2004). Graduate Theses, Dissertations, and Problem Reports. 1541.

https://researchrepository.wvu.edu/etd/1541

This Thesis is protected by copyright and/or related rights. It has been brought to you by the The Research Repository @WVU with permission from the rights-holder(s). You are free to use this Thesis in any way that is permitted by the copyright and related rights legislation that applies to your use. For other uses you must obtain permission from the rights-holder(s) directly, unless additional rights are indicated by a Creative Commons license in the record and/ or on the work itself. This Thesis has been accepted for inclusion in WVU Graduate Theses, Dissertations, and Problem Reports collection by an authorized administrator of The Research Repository @ WVU. For more information, please contact researchrepository@mail.wvu.edu. 


\title{
Channel Geomorphology Relationships for the Beaver Creek Watershed
}

\author{
By \\ Atif Hamid \\ Thesis submitted to the College of Engineering and Mineral Resources \\ at West Virginia University \\ in partial fulfillment of the requirements \\ for the degree of \\ Master of Science \\ in \\ Civil Engineering
}

\author{
Approved By \\ Donald D. Gray, Ph.D., P.E., Chair \\ Roger C. Viadero, Jr., Ph.D. \\ Ronald H. Fortney, Ph.D. \\ Robert N. Eli, Ph.D., P.E.
}

Department of Civil and Environmental Engineering

Morgantown, West Virginia

2004

Keywords: Regional Curve, Stream Geometry, Fluvial Morphology, Hydraulic

Geometry, Bankfull, Regional Regression Analysis, Stream Restoration, HEC-RAS,

HEC-HMS

Copyright 2004 Atif Hamid 


\title{
ABSTRACT \\ Channel Geomorphology Relationships for the Beaver Creek Watershed
}

\author{
by Atif Hamid
}

The proposed Appalachian Corridor $H$ will be built through some of the most rugged terrain in West Virginia. The Corridor $H$ section from Davis to Bismarck passes through the Beaver Creek watershed, located in Tucker County, West Virginia, which has been heavily affected by historic mining, deteriorating the water quality conditions of the Beaver Creek watershed. Due to the construction of Corridor H, some of the streams will be disturbed from their present courses. Hence, stream restoration work for these streams is inevitable. It is important to develop a family of stream geometry curves that relate the bankfull parameters as functions of drainage area to carry out stream restoration works.

A set of empirical equations and curves has been developed for the Beaver Creek watershed that provide the "bankfull flow" discharge, cross-sectional area, width, and depth as functions of drainage area for streams located in the watershed. The data set for the analysis included 4 streams evolving from mineland spoils, 4 natural tributaries to Beaver Creek and 2 locations on Beaver Creek itself. The drainage areas for the streams ranged from $0.04 \mathrm{mi}^{2}-22.18 \mathrm{mi}^{2}$. It is important to know that many streams that evolve from mineland spoils show lateral expansion and have not yet stabilized. The topographic break along the bank and the top of meander bend point bars were determined as the most reliable bankfull indicators. The flows of these stream sites corresponding to these indicators had a recurrence interval of about 1.46 years, which is consistent with the gage station analyses throughout the United States. Positive results by the use of numerical and hydrologic models used in this study show the accuracy and state of the art advancement of such models and that they can be used to infer bankfull flows without having to rely on gaged data. These relationships are essential for use in designing restoration or stabilization of unstable reaches in similar hydrophysiographic regions. 


\section{ACKNOWLEDGMENTS}

My very sincere appreciation is extended to my thesis advisor Dr. Donald Gray, for his guidance, encouragement, and constructive suggestions, which contributed much to this study. I would like to thank Dr. Fortney whose continued encouragement led to the decision of attempting this study and also for providing his time and effort in the field for proper determination of bankfull indicators.

I would also like to thank Dr. Viadero and Dr. Eli for their valuable support and guidance from time to time during the course of the study.

I wish to thank Mr. William Ravenscroft for his able assistance with the field work and also with the Arc GIS programming tools. My sincere thanks to Mr. Scott Copen for his help in the field and valuable advice over the subject.

I would especially like to thank my wife, Sabiha Hamid, who, was a source of inspiration and assisted me in the field work and draft of the thesis. Without her moral support and encouragement, this research would not have been possible.

Finally, my sincere thanks to my family and friends for their love and support which has been a source of strength and motivation to complete my thesis.

This work was supported in part by the West Virginia Division of Highways (WVDOH), to whom I am grateful. The views expressed in this thesis are mine and have not been endorsed by the WVDOH. 


\section{TABLE OF CONTENTS}

TITLE PAGE ...................................................................................................................

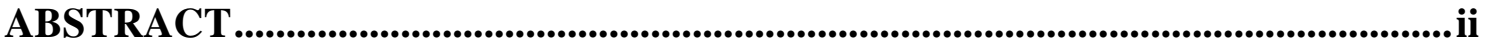

ACKNOWLEDGMENTS .........................................................................................ii

TABLE OF CONTENTS ..................................................................................... iv

LIST OF TABLES ............................................................................................................ vi

LIST OF FIGURES ...............................................................................................

CHAPTER 1.0 INTRODUCTION ........................................................................ 1

$1.1 \quad$ Problem Statement ............................................................................... 1

$1.2 \quad$ Goals And Objectives .................................................................. 1

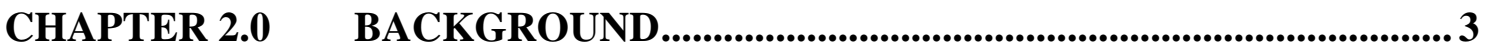

$2.1 \quad$ Introduction ......................................................................................... 3

$2.2 \quad$ Natural Channel Design........................................................................ 3

2.3 Theory Of Channel Forming Discharge............................................ 4

2.4 Determination Of Bankfull Discharge...............................................5

$2.5 \quad$ Recurrence Interval Discharge ........................................................... 6

2.6 Bankfull Geometry And Regional Curve ......................................... 7



3.1 Regional Regression Equation For Peak Flows............................10

3.2 HEC-RAS Numerical Model ........................................................12

Hydrologic Parameters .................................................................... 14

3.3.1 Dimensionless Unit Hydrograph (SCS) .........................14

3.3.2 Infiltration Loss Method (SCS Method) .......................17

3.3.2.1 Soil Classification .................................................. 18

3.3.2.2 Curve Number ..................................................... 21

3.3.2.3 Rainfall-Runoff Relationship .......................... 24

3.3.3 Time Of Concentration..................................................... 26

3.3.4 Baseflow ................................................................................... 30 


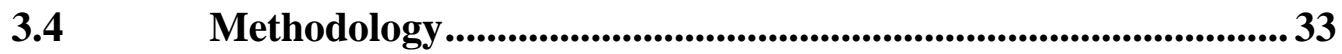

The Study Sites ................................................................................. 37

3.5.1 Description Of Sub-basins.................................................. 40

3.5.2 Reach Pictorials.............................................................. 42

CHAPTER 4.0 COMPUTATION AND RESULTS .............................................5 52

4.1 HEC-RAS Analysis....................................................................... 52

4.2 Power Function Regression Equations.......................................... 54

4.3 Confidence Interval Band For The Regional Curves.................60

4.4 Determination Of Bankfull Return Period ....................................61

4.4.1 Regional Regression Analysis .........................................61

4.4.2 HEC-HMS Analysis ............................................................62

CHAPTER 5.0 DISCUSSION AND CONCLUSION...........................................68

5.1 Lateral Widening Of Mineland Tributaries .................................68

5.2 Verification Of Results................................................................. 70

5.3 Morphological Factors Affecting Evolution Of

Mineland Streams........................................................................ 72

5.4 State Of The Art Advancement Of Computer Models .............. 73

5.5 Summary And Conclusion................................................................. 75

CHAPTER 6.0 SCOPE OF FURTHER RESEARCH .......................................... 77

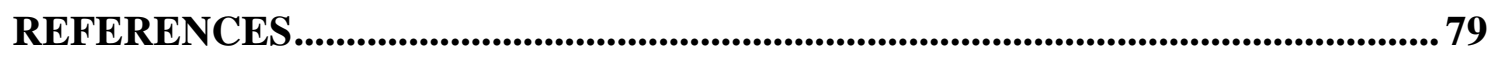

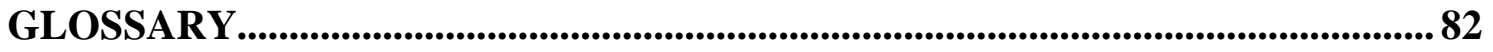

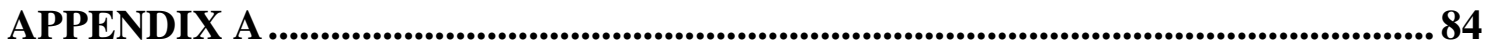




\section{LIST OF TABLES}

TABLE

PAGE

Table 3.1 - Description Of Hydrologic Soil Groups (USDA SCS, 1985)..................... 18

Table 3.2 - Hydrologic Classification Of Beaver Creek Watershed Soils...................... 19

Table 3.3 - Runoff Curve Numbers For Hydrologic Soil-Cover Complexes Of

Beaver Creek Watershed........................................................................ 22

Table 3.4 - Overland-Flow Roughness Coefficients For Sheet-Flow Modeling

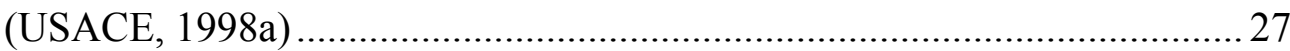

Table 3.5 - Average Monthly Baseflow For Different Sub-Basins Of Beaver

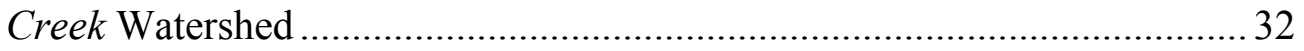

Table 3.6 - Hydrological Features Of The Sub-basins And Tributaries ........................ 35

Table 3.7 - Hydrological Description Of The Study Basins And Tributaries ............... 41

Table 4.1 - Geometric Parameters of Reaches At Bankfull Depth ............................... 55

Table 4.2 - Regional Regression Equation Peak Discharges $(1.1$ - 3 years $)$................. 62

Table 4.3 - Time Of Concentration And Lag Time Using SCS Curve Number

Method And SCS Divided Flow Section Method......................................64

Table 4.4 - TP-40 Average 24-Hour Precipitation For Various Return Periods ............ 65

Table 4.5 - Peak Discharges For Various Return Period Using HEC-HMS ................. 66

Table 4.6 - Bankfull Discharge And Return Period For Various Sub-Basins ................ 67

Table A-1 - Hydraulic Characteristics Of MT1 Obtained From HEC-RAS. ................ 85

Table A-2 - Hydraulic Characteristics Of MT2 Obtained From HEC-RAS. ................. 85

Table A-3 - Hydraulic Characteristics Of MT3 Obtained From HEC-RAS. ................. 86

Table A-4 - Hydraulic Characteristics Of MT4 Obtained From HEC-RAS. ................. 86

Table A-5 - Hydraulic Characteristics Of NMT1 Obtained From HEC-RAS............... 87

Table A-6 - Hydraulic Characteristics Of NMT2 Obtained From HEC-RAS................ 87

Table A-7 - Hydraulic Characteristics Of NMT3 Obtained From HEC-RAS................ 88

Table A-8 - Hydraulic Characteristics Of UBC Obtained From HEC-RAS. ................. 88

Table A-9 - Hydraulic Characteristics Of NMT4 Obtained From HEC-RAS................ 89

Table A-10 - Hydraulic Characteristics Of LBC Obtained From HEC-RAS................. 89 


\section{LIST OF FIGURES}

FIGURE

PAGE

Figure 2.1 - Stage-Discharge Curve For A Gaged Stream ......................................... 5

Figure 2.2 - Regional Curve By Emmet (1975) .................................................... 8

Figure 2.3 - Regional Curve Representations .................................................... 9

Figure 3.1 - Definition Sketch For Step Backwater Calculations................................. 13

Figure 3.2 - Mass Curve Of SCS Unit Hydrograph................................................... 14

Figure 3.3 - Hydrologic Classification Of Beaver Creek Watershed Soils .................... 20

Figure 3.4 - Land Cover Types Of Beaver Creek Watershed...................................... 23

Figure 3.5 - Relationship Between Precipitation, Infiltration And Runoff.................... 24

Figure 3.6 - Hydrograph Separation Into Overland Flow And Baseflow Components.. 31

Figure 3.7 - Location Of Beaver Creek Watershed In West Virginia ........................... 38

Figure 3.8 - Sub-Basin Watershed Boundaries Of Beaver Creek Watershed................. 39

Figure 3.9 - Upstream View Of Study Reach For MT1 ........................................... 42

Figure 3.10 - Perspective View Of Study Reach For MT1 ........................................... 42

Figure 3.11 - Upstream View Of Study Reach For MT2 ............................................ 43

Figure 3.12 - Perspective View Of Study Reach For MT2 …................................... 43

Figure 3.13 - Typical Cross-section Of MT3 ............................................................ 44

Figure 3.14 - Perspective View Of Study Reach For MT3 ........................................... 44

Figure 3.15 - Downstream View Of Study Reach For MT4 ........................................ 45

Figure 3.16 - Perspective View Of Study Reach For MT4 ….................................... 45

Figure 3.17 - Typical Cross-section Of NMT1 …...................................................... 46

Figure 3.18 - Perspective View Of Study Reach For NMT1 ...................................... 46

Figure 3.19 - Upstream View Of Study Reach For NMT2 ........................................ 47

Figure 3.20 - Perspective View Of Study Reach For NMT2 ..................................... 47

Figure 3.21 - Downstream View Of Study Reach For NMT3 .................................... 48

Figure 3.22 - Perspective View Of Study Reach For NMT3 ...................................... 48

Figure 3.23 - Downstream View Of Study Reach For UBC ..................................... 49

Figure 3.24 - Perspective View Of Study Reach For UBC ...................................... 49

Figure 3.25 - Downstream View Of Study Reach For NMT4 ................................... 50 
Figure 3.26 - Perspective View Of Study Reach For NMT4 .................................... 50

Figure 3.27 - Downstream View Of Study Reach For LBC ...................................... 51

Figure 3.28 - Perspective View Of Study Reach For LBC .......................................51

Figure 4.1 - Typical Bankfull Cross-Section For MT4............................................... 52

Figure 4.2 - Typical Cross-Section Of Reach MT4 At Bankfull Discharge................... 53

Figure 4.3 - Bankfull Discharge As A Function Of Drainage Area ..............................56

Figure 4.4 - Bankfull Cross-Sectional Flow Area As A Function Of Drainage Area .... 57

Figure 4.5 - Bankfull Width As A Function Of Drainage Area....................................58

Figure 4.6 - Bankfull Depth As A Function Of Drainage Area ....................................59

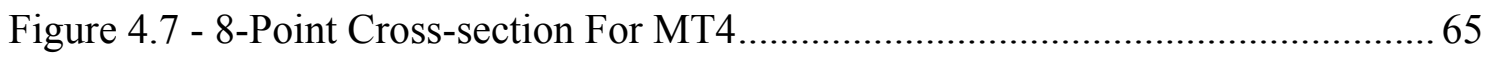

Figure 4.8 - Bankfull Return Period Versus Drainage Area....................................... 67

Figure 5.1 - Power Relationship For Bankfull Width To Drainage Area

Excluding Mineland Streams.......................................................... 68

Figure 5.2 - Channel Photograph Showing Horizontal Widening And Bed Load Upstream Of MT2 Looking Upstream

Figure 5.3 - Comparison Of Average Values Of Bankfull Channel Dimensions As Functions Of Drainage Area 


\section{CHAPTER 1 INTRODUCTION}

\subsection{Problem Statement}

The proposed Appalachian Corridor $H$ will be built through some of the most rugged terrain in West Virginia. The Corridor $H$ section from Davis to Bismarck passes through the Beaver Creek watershed, located in Tucker County, West Virginia, which has been heavily affected by historic mining, deteriorating the water quality conditions of the Beaver Creek watershed. Due to the construction of Corridor H, some of the streams will be disturbed from their present courses. Hence, stream restoration work for these streams is inevitable. It is important to know that many of these streams have not yet stabilized and that very little has been done to develop regional curves for the watershed. Preliminary results for the development of channel geomorphology relationships for rural watersheds and reclaimed mine lands in Beaver Creek watershed region are presented in this study.

Gage station analysis throughout the United States has shown that the bankfull discharge has an average return interval of 1.5 years or $67 \%$ annual exceedence probability (Dunne and Leopold, 1978; Leopold, 1994). Determination of the bankfull recurrence interval for the Beaver Creek watershed would help explain the hydrologic characteristics of the streams evolving from mine spoils and the difference with respect to other streams.

\subsection{Goals And Objective}

A set of empirical equations and curves that provide bankfull flow geometry parameters such as discharge, depth, width, and cross-sectional area versus the drainage area is very useful in the design and analysis of streams in a given hydrologic area. This is specially true for stream restoration purposes where channel geometry is altered due to human intervention. Land use changes, partially reclaimed mining, removal of riparian vegetation, and other disturbances may lead to channel instability. The associated bank erosion, scouring, and deposition of bed materials results in degraded water quality and stream widening. An altered stream channel with a wider channel width and larger crosssectional area may not transfer its bed-load as efficiently as an undisturbed stream 
channel because of low velocity and subsequently more gravel deposition. A family of regional stream geometry curves can help evaluate impaired/disturbed sites, design channel restoration projects, and re-establish "natural" regimes with more efficient transport of bed loads.

Reference stream channel morphology relationships are valuable tools for engineers, hydrologists and biologists to determine appropriate channel dimensions, patterns, and profiles for various stream types and watershed conditions. The objective of this study is to develop geomorphic relationships for the streams in the Beaver Creek watershed, located in Tucker County, West Virginia.

Since there are no gaging stations available for any streams in the Beaver Creek watershed, numerical models have to be relied upon for development of geomorphic relationships. Proper field determination of hydrologic features is very important to aid in the development of regional curves. It is intended to use the Hydrologic Engineering Center - River Analysis System (HEC-RAS) computermodeling system to predict the bankfull flows and geometry for the Beaver Creek. Once the channel bankfull flows are determined, the return period of the bankfull events will be determined using regression equations and numerical models.

The National Flood Frequency (NFF) Program developed by the United States Geological Survey (USGS) in cooperation with the Federal Highway Administration (FHA) and the Federal Emergency Management Agency (FEMA) has published a computer program that evaluates regression equations for estimating $T$-year flood-peak discharges for rural and urban watersheds. More recently, similar regional regression equations have been developed for estimating peak discharges with recurrence intervals between 1.1 and 3 years for rural unregulated streams in West Virginia (Wiley et al., 2002). Numerical models such as the Hydrologic Engineering Center - Hydrologic Modeling System (HEC-HMS) are also useful in simulating rainfall-runoff relationships (Tummala, 2003). The regional regression equations and the HEC-HMS models are used to predict bankfull return periods for the Beaver Creek watershed for this study. 


\section{CHAPTER 2 BACKGROUND}

\subsection{Introduction}

Bankfull hydraulic geometry relationships, also called regional curves, relate bankfull channel dimensions to drainage area (Dunne and Leopold, 1978). Gage station analysis throughout the United States has shown that the bankfull discharge has an average return interval of 1.5 years or $67 \%$ annual exceedence probability (Dunne and Leopold, 1978; Leopold, 1994). Leopold (1994) stated that most investigations have concluded that the bankfull discharge recurrence interval ranged from 1.0 to 2.5 years. Variations in the determination of bankfull return interval are discussed later in this chapter. Although the assumption that the channel-forming flow has a recurrence interval of 1.5 years is sufficient for reconnaissance-level studies, it should not be used for design until verified through inspection of reference reaches, data collection, and analysis. This is especially true in highly modified streams such as in urban or mined areas. A primary purpose for developing regional curves is to aid in identifying bankfull stage and dimensions in ungaged watersheds and to help estimate the bankfull dimensions and discharge for natural channel designs (Rosgen, 1994).

\subsection{Natural Channel Design}

Over the past, engineers, hydrologists and designers have focused on designing rivers and streams to convey water away from the populated areas with maximum efficiency. Human intervention and urbanization also lead to changes in the natural configuration of stream channels. Such interference and involvement brings about changes in the stream dimension, pattern, and profile, disturbing the natural equilibrium and resulting in instability of the stream in the long term. It is therefore very important to incorporate knowledge of fluvial geomorphology in designing a stream channel that is in balance with natural processes. Current management practices look forward to engineering design approaches that focus on realignment of rivers and streams with forms that emulate those of natural watercourses.

One of the most comprehensive applications of fluvial geomorphology in river and stream engineering is 'natural channel design'. It involves configuring the forms of 
the river to achieve the stability characteristic of natural conditions. The intent of this approach is to replicate the channel form that would naturally occur given the hydrologic and sediment regimes of the upstream drainage basin. The objective of this practice is to achieve the self-regulating stability of form that characterizes natural rivers and streams. This reduces damage to property and infrastructure and improves the aesthetic value and ecological function of the watercourse.

Continuing human interference and development, requires channel relocation and protection of individuals and property from flooding and erosion. Natural channel designs are useful to replace past modifications that are failing to regain stability lost due to human intervention.

Because rainfall/runoff relationships vary by province and land cover, separate bankfull hydraulic geometry relationships need to be developed for rural and urban areas for each physiographic province to support natural channel design procedures. The stream channel morphology relationships are also used at a given site to determine if stream channel geometry has become unstable. Development of a set of empirical equations and curves, specific to the Beaver Creek watershed, would help in design of the channels relocated due to the construction of Corridor $H$.

\subsection{Theory Of Channel Forming Discharge}

A stream adjusts the dimensions of its channel to accommodate the wide range of flows that mobilize its boundary sediments. A single representative discharge may be used to determine stable channel geometry for many streams and channels. The bankfull discharge is considered to be the channel-forming agent that maintains channel dimensions and transports the bulk of sediment over time. In stable channels, bankfull discharge corresponds closely with effective discharge and channel forming discharge. The effective discharge is defined as the discharge that transports the largest fraction of the sediment load over a period of years. The channel forming discharge is defined as a theoretical discharge that if maintained indefinitely would produce a channel geometry in equilibrium condition. Channel forming (dominant) discharge can be estimated by determining the bankfull discharge where the channel conveys its maximum discharge without flowing onto its floodplains. The specified recurrence interval discharge, 
typically between the mean annual and five-year peak is also used to represent the channel forming discharge. Finally, the effective discharge that transports the largest fraction of bed load over a period of years can be representative of the channel forming (dominant) discharge.

\subsection{Determination of Bankfull Discharge}

The bankfull discharge is the discharge that fills an alluvial channel up to the elevation of the active floodplain. In many natural channels this is the discharge that just fills the cross-section without overtopping the bank. It can be said that a stable channel is most efficient in transporting the sediments and water at the bankfull stage. Determination of bankfull or channel forming flow depth may be difficult. The stage-discharge curve of a gaged stream can indicate bankfull discharge by a change in slope as shown in Figure 2.1.



Figure 2.1 - Stage-Discharge Curve For A Gaged Stream. (USDA NRCS, 2001).

Stream dimensions, patterns and bed features associated with the longitudinal river profile are generally described as functions of channel width measured at bankfull stage (Rosgen 1994). Correct and reliable interpretation of the interrelationships between dimensions, pattern, profile and streamflow depends upon the correct field identification of bankfull stage and the related discharge. 
The most consistent bankfull stage determination is obtained from identification of the top of the floodplain. This elevation is where incipient flooding begins for those flows that extend above the bankfull stage. The elevation of the top of the point bars and the bankfull stage share a common elevation that is directly related to the development of floodplains within the valley. Where floodplains are not well developed, field stage indicators as listed below determine the bankfull stage.

- A break in the slope of the banks where the banks become almost horizontal.

- A scour line along the rocks on the banks of the channel.

- Evidence of exposed root hairs below an intact soil layer subjected to erosive flows along the banks.

- A line distinctive of a change in vegetation along the banks.

Using vegetation to identify bankfull stage must be done cautiously since some species can establish themselves on suitable substrate well within the boundaries of the bankfull channel. The elevation of bankfull stage is frequently underestimated when determining solely on the basis of vegetation. Such single criterion determinations must be avoided. Field indicators are often subtle or missing and are not valid if the stream is not stable and alluvial.

Gaged stations have rating curves from which bankfull stage and discharge can easily be identified. It has been suggested to first measure bankfull cross-sections and longitudinal profiles at gaged station reaches (Rosgen 1994). This allows one to compare the interpretations of geomorphic bankfull stage features to known streamflows and the corresponding return period. The watershed considered in this study does not have a gaged stream; hence, a very careful field identification of the bankfull stage is required. The stream cross-section is fed into the HEC-RAS model and various flows are simulated to match the water level with the observed elevation to get the bankfull flow for the reach.

\subsection{Recurrence Interval Discharge}

To avoid some of the problems relating to field determination of bankfull stage, the channel forming discharge is often assumed to represent a specific recurrence interval discharge. In general, bankfull discharge in stable channels has been found to 
correspond to an annual flood recurrence interval of approximately 1 to 2.5 years and the 1.5-year recurrence flood has been shown to be a representative mean of many streams (Leopold 1994). The earliest estimate of the channel forming discharge was the mean annual flow (Leopold and Maddock 1953). Wolman and Loepold (1957) suggested that the channel-forming discharge has a recurrence interval of 1-2 years. Dury (1973) concluded that the channel forming discharge is approximately $97 \%$ of the 1.58 -year discharge or the most probable annual flood. Hey (1975) showed that for 3 British gravelbed rivers, the 1.5-year flow in an annual maximum series passed through the scatter of bankfull discharges measured along the course of the rivers. Richard (1992) suggested that in a partial duration series, bankfull discharge equals the most probable annual flood, which has a one-year return period.

However there are many instances where the bankfull discharge doesn't fall within this range. For example, Pickup and Warner (1976) determined bankfull recurrence intervals ranged from 4 to 10 years based on the annual series. Williams (1978) determined that approximately $75 \%$ of 51 streams that he analyzed appeared to have bankfull discharge recurrence intervals between 1.03 and 5.0 years. The range in return intervals for 19 of the 28 streams was from 1.01 to 32 years. Of the 28 streams, 9 had bankfull discharge recurrence intervals of less than 1 year.

\subsection{Bankfull Geometry And Regional Curve}

Bankfull channels are described by characteristics such as cross-sectional area, width, and mean depth. Bankfull channel dimensions of cross-sectional area, width, and mean depth tend to increase with an increase in drainage area (Leopold et al. 1964). A linear variation is observed in a power log plot. When time or resources do not permit field determination of bankfull discharge or data are unavailable to calculate the effective discharge, indirect methods based on regional hydrologic analysis may be used. In the simplest from, regional analysis entails regression techniques to develop empirical relationships applicable to homogeneous hydrologic regions. Estimates of bankfull dimensions are helpful for confirming field identification of the bankfull channel. 


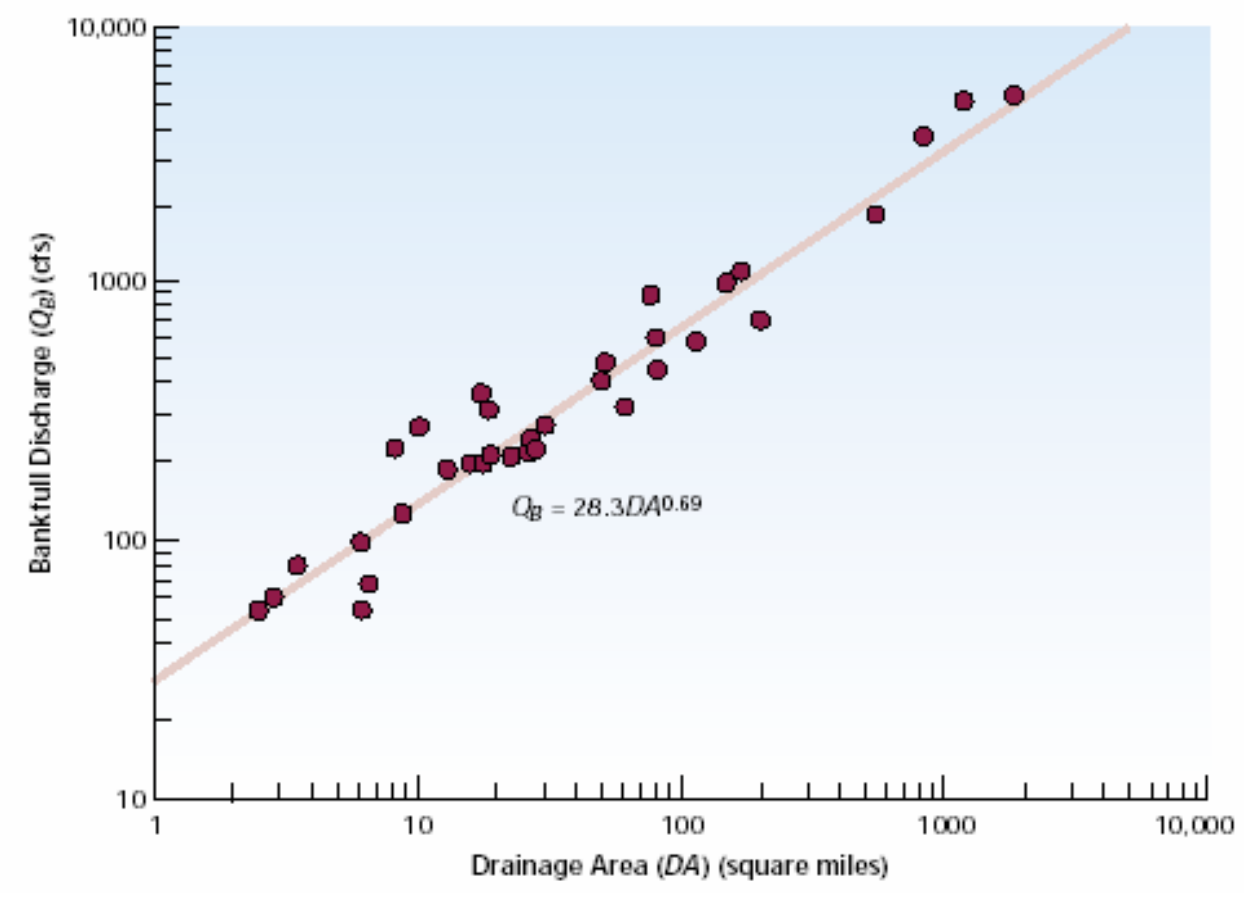

Figure 2.2 - Regional Curve By Emmet (1975).

A regional curve is a regression of these relations and provides estimated channel dimensions and streamflow for the bankfull channel when drainage area is known. Regional relationships of bankfull discharge versus drainage area can provide good starting points for selecting a channel forming discharge for restoration purposes. Within hydrologically homogeneous regions, runoff increases with watershed drainage area. Once developed, investigators can use regional curves at unmonitored sites to support or refute their identification of bankfull channels within regions having similar runoff characteristics. Dunne and Leopold (1994) developed average curves relating bankfull discharge to drainage area for widely separated regions in the United States. A similar curve can be seen in Figure 2.2 from a work done by Emmet (1975) in the upper Salmon River area, Idaho. The bankfull channel dimensions, stratified on the basis of four hydro-physiographic regions of United States, are shown in Figure 2.3. 


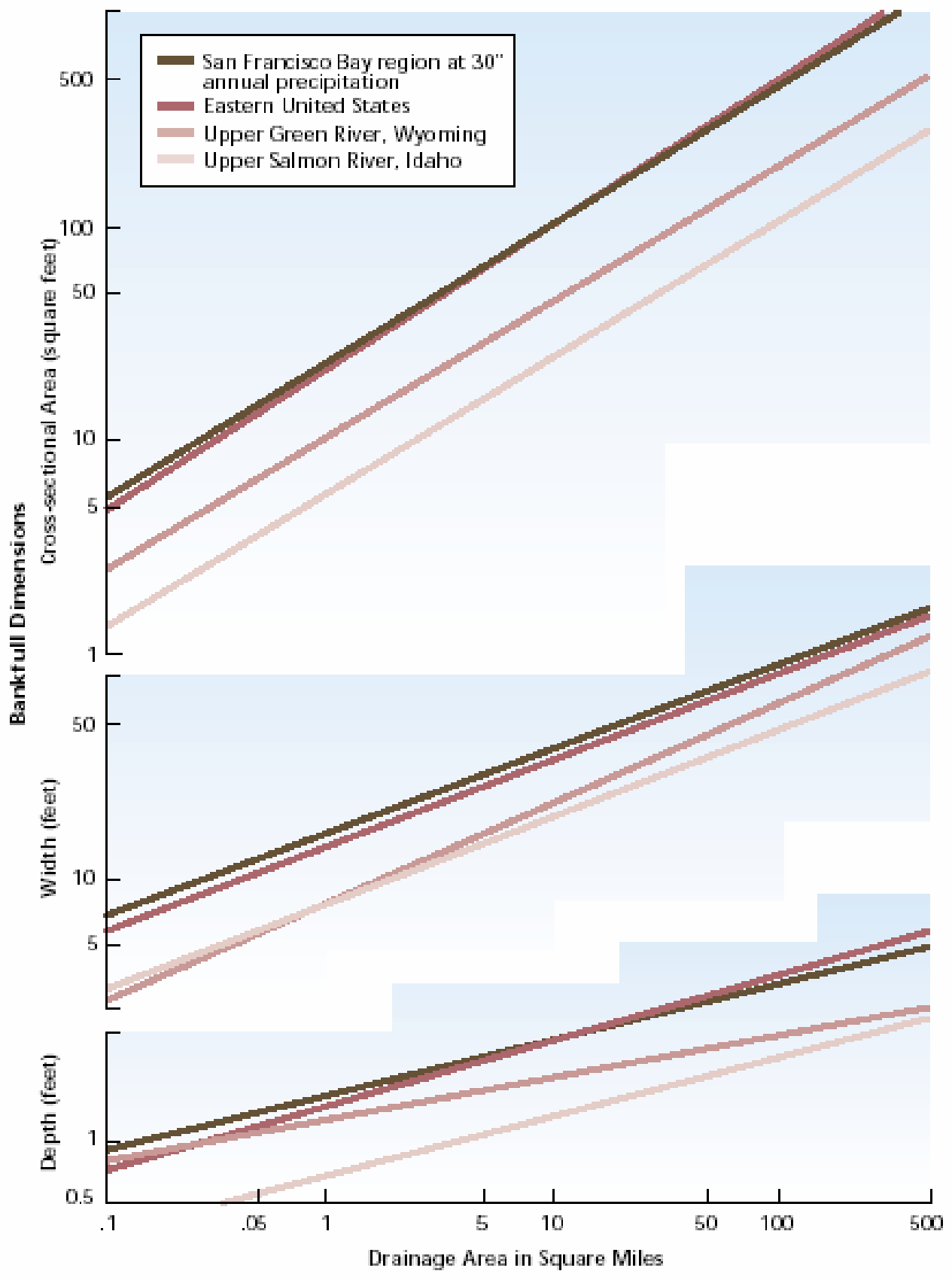

Figure 2.3 - Regional Curve Representations (Dunne and Leopold, 1978). 


\section{CHAPTER 3 THEORY}

\subsection{Regional Regression Equation For Peak Flows}

For many years, the U.S. Geological Survey (USGS) has been developing regional regression equations for estimating food magnitude and frequency at ungaged sites. In 1994, the USGS released a computer program titled the National Flood Frequency Program (NFF), which compiled all the available USGS regression equations for estimating the magnitude and frequency of floods in the United States and Puerto Rico. The NFF program uses a nationwide database of regional regression equations to compute peak discharges for the 2, 5, 10, 25, 50, 100, and 500-year storm events. Each state is divided into homogeneous hydrologic flood regions and regression equations have been determined for each region. The initial flood-estimating equations for West Virginia were developed from peak discharge records available at 170 sites for rural, unregulated, streams. The equations were recommended for use on natural streams with drainage areas between 0.3 and 2,000 $\mathrm{mi}^{2}$ (Runner 1980b).

Improved regional equations for the 2, 5, 10, 25, 50, 100, 200, and 500-year peak discharges were determined by generalized least-squares regression using data from 236 gaging stations by Wiley et al. (2000) for three regions of the State, designated East, North, and South. The equations are applicable only to rural, unregulated, streams within the boundaries of West Virginia and are not applicable to

- Urban areas having paved surfaces, concrete channels, or culverts,

- Streams regulated by dams, or large lakes and ponds,

- Heavily mined areas if excessive runoff is diverted into or outside the basin, retained along strip benches, or retained underground,

- Karst areas if excessive run-off is diverted into, outside, or within the basin through solution channels or other cavities in carbonate (limestone and dolomite) rocks.

The newly revised regression equations replaced those published by Runner (1980b). Determination of peak discharge estimates depends on whether the stream is gaged, ungaged or has a gaging station on the same stream. The average standard error of prediction ranged from 27.7 to 44.7 percent. It was suggested not to apply the 
equations if the drainage area falls outside the range of values used to develop the equations.

Later in 2002, Wiley et al. presented equations for estimating peak discharges with recurrence intervals between 1.1 and 3 years for rural unregulated streams in West Virginia using the same data. These equations provide estimates of peak discharge at ungaged locations. The new equations have the same limitations as described earlier in the improved regression equations by (Wiley et al., 2000).

The location of Beaver Creek falls in the East region of West Virginia and the following regression equations are used to estimate the peak discharge:

$$
\begin{aligned}
& Q(1.1)=31.7 A^{0.834} \\
& Q(1.2)=37.9 A^{00.835} \\
& Q(1.3)=42.6 A^{0.836} \\
& Q(1.4)=46.5 A^{0.837} \\
& Q(1.5)=49.9 A^{0.838} \\
& Q(1.6)=53.0 A^{0.838} \\
& Q(1.7)=55.8 A^{0.839} \\
& Q(1.8)=58.4 A^{0.839} \\
& Q(1.9)=60.9 A^{0.84} \\
& Q(2)=62.6 A^{0.842} \\
& Q(2.5)=72.9 A^{0.842} \\
& Q(3)=80.2 A^{0.843}
\end{aligned}
$$

where,

$Q(T)$ - Return interval discharge in cubic feet per second;

$A$ - Drainage area in square miles; and

$T$ - Return period in years. 


\subsection{HEC-RAS Numerical Model}

HEC-RAS (Hydrologic Engineering Center - River Analysis System), an

Army Corps of Engineers computer program, is the successor to the steady-flow HEC-2 program. The HEC-RAS program calculates one-dimensional steady flow river hydraulics. In addition to steady flow, HEC-RAS can model unsteady flow and sediment transport. It includes hydraulic design capabilities.

HEC-RAS is an integrated hydraulics package, designed for interactive use in a multi-tasking environment (Windows ${ }^{\mathrm{TM}}$ ). The system uses a Graphical User Interface (GUI) for file management, data entry and editing, program execution, and output display. The current (2003) release provides steady-flow, subcritical, supercritical, and mixed-flow regime profile calculations for a river network.

Flow profile analysis is usually carried out by surveying a series of channel cross-sections and carrying out gradually varied flow calculations using a computer package such as HEC-RAS, which uses the standard step method (Chow, 1959). Where flow is sub-critical, the calculations are carried out cross-section by cross-section in the upstream direction using standard step analysis.

The standard step method assumes flow conditions that are steady with time and gradually varied in space. Flow is described by the one-dimensional energy conservation equation; and a uniform flow formula, such as the Manning equation, is used to evaluate the energy slope at each cross-section. The energy conservation equation for the reach is given by:

$Z_{1}+Y_{1}+\frac{\alpha_{1} v_{1}^{2}}{2 g}=Z_{2}+Y_{2}+\frac{\alpha_{2} v_{2}^{2}}{2 g}+h_{e}$

where:

$Z$ - Channel bed elevation;

$Y$ - Flow depth;

$g$ - Gravitational acceleration;

$v$ - Mean flow velocity;

$\alpha$-Coefficient accounting for non-uniform velocity distribution;

$h_{e}-$ Head loss between cross-sections. 


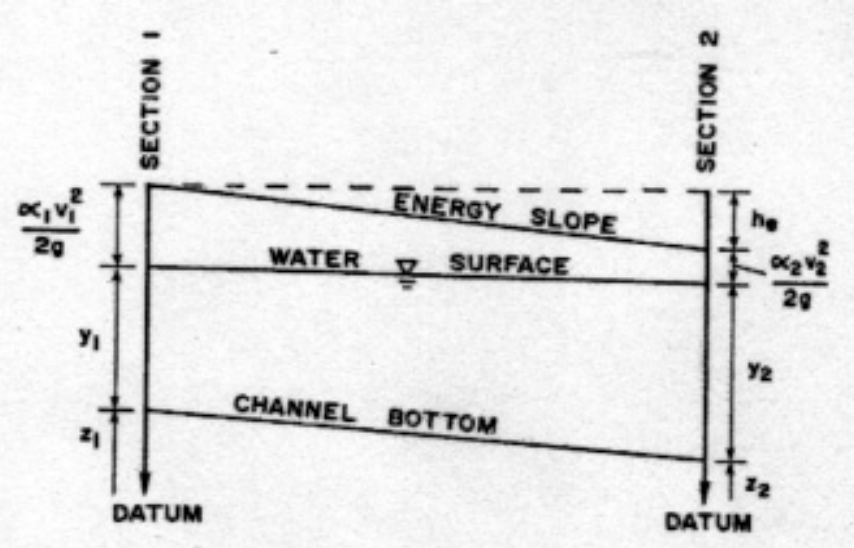

\section{Figure 3.1 - Definition Sketch For Step Backwater Calculations.}

Head loss consists of frictional losses created by boundary roughness elements, eddy losses associated with turbulence, and flow separation generated by channel contraction and expansion. Frictional losses are estimated by the Manning equation:

$S_{f}=\frac{n^{2} v^{2}}{R^{4 / 3}}$

where,

$S_{f}$ - Local frictional slope;

$n$ - Roughness coefficient; and

$R-$ Hydraulic radius.

Eddy losses are calculated from the change in the velocity head between crosssections:

$k\left|\frac{\alpha_{1} v_{1}^{2}}{2 g}-\frac{\alpha_{2} v_{2}^{2}}{2 g}\right|$

where $k$ is taken as $0.0-0.1$ for narrowing reaches $0.2-0.5$ for expanding reaches. 


\subsection{Hydrologic Parameters}

\subsubsection{Dimensionless Unit Hydrograph (SCS)}

To estimate the peak discharge and establish a runoff hydrograph in the Soil Conservation Service (SCS) Method, the concept of a dimensionless unit hydrograph is applied. The Soil Conservation Service dimensionless unit hydrograph was derived from analysis of a large number of unit hydrographs developed using gage data from watersheds of a wide range in size and geographical location. The dimensionless unit hydrograph has ordinate values expressed in a dimensionless ratio $q / q_{p}$ and abscissa values of $t / T_{p}$, where $q_{p}$ is the peak discharge at $T_{p}$ and $q$ is the discharge at time $t$. Figure 3.2 shows the shape of the dimensionless unit hydrograph. At the same time, the mass curve is also illustrated in Figure 3.2 with ordinates of $Q_{a} / Q$ versus $t / t_{p}$, in which $Q_{a}$ is the accumulated volume at time $t$, and $Q$ is the total volume. The curvilinear unit hydrograph can be approximated by an equivalent triangular unit hydrograph, as shown by the dashed lines in Figure 3.2.

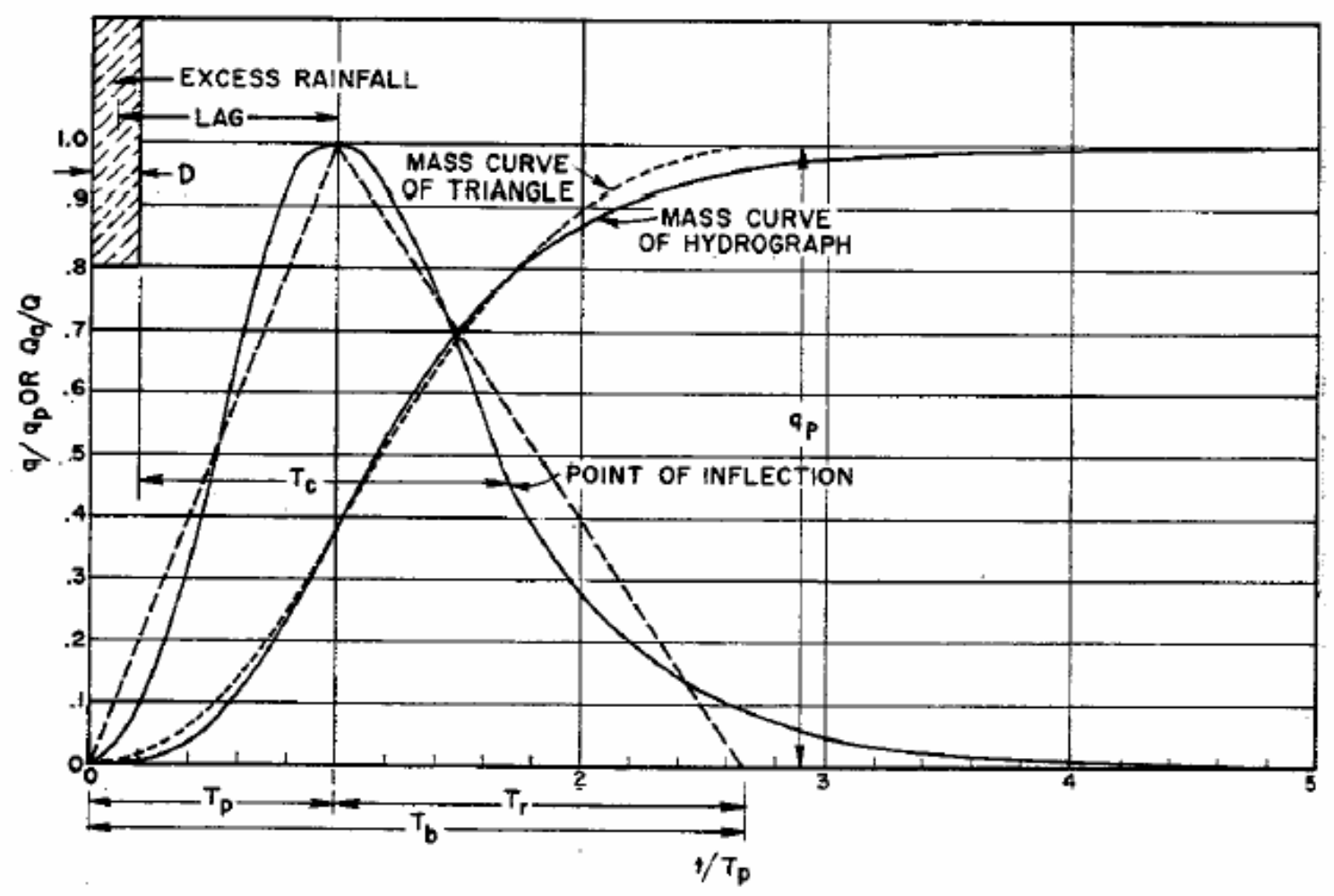

Figure 3.2 - Mass Curve Of SCS Unit Hydrograph (SCS, 1972). 
The transformation from curvilinear unit hydrograph to triangular unit hydrograph provides a solution for the peak flow. The areas under the rising limb (before time $T_{p}$ ) of the two unit hydrographs are defined to be the same. The time base of the dimensionless unit hydrograph is five times the time-to-peak $\left(T_{p}\right)$, while the time base of the triangular unit hydrograph is only 2.67 times the time-to-peak $\left(T_{p}\right)$. The area under both unit hydrographs in Figure 3.2 equals the volume of direct runoff $Q$.

Using the geometry of the triangular unit hydrograph and the conversion factors, the peak discharge can be estimated by:

$q_{p}=\frac{484 A Q}{T_{p}}$

where,

$q_{p}$ - Peak discharge in cfs;

$A$ - Drainage area in square miles;

$Q$ - Direct runoff in inches;

$T_{p}$ - Time to peak in hours;

Since the volume under the rising side of the triangular unit hydrograph is equal to the volume under the rising side of the curvilinear dimensionless unit hydrograph in Figure 3.2, the constant 484, or peak rate factor, is valid for calculation of the peak discharge for the dimensionless unit hydrograph. The constant 484 reflects a unit hydrograph that has $3 / 8$ of its area under the rising limb. For mountainous watersheds, the fraction under the rising limb could be expected to be greater, and the constant in Equation (16) may be nearer 600. For flat, swampy areas the constant may be on the order of 300 (NEH Section 4, Snider, 1972).

Figure 3.2 also shows that the time to peak is related to the duration of excess rainfall $\Delta D$ and lag time; $T_{\text {lag }}$ by:

$$
T_{p}=\frac{\Delta D}{2}+T_{\text {lag }}
$$

For ungaged watersheds, the SCS suggests that the Unit Hydrograph lag time may be related to the time of concentration, $T_{c}$, as:

$T_{\text {lag }}=0.6 T_{c}($ Kent, 1972) 
Using equation (17) and (18) equation (16) can be written as:

$q_{p}=\frac{484 A Q}{\frac{\Delta D}{2}+0.6 T_{c}}$

The time of concentration; $T_{c}$ is defined the time difference between the end of rainfall excess and the point of inflection on the falling limb. Figure 3.2 shows the point of inflection is approximately 1.7 times $T_{p}$. Therefore,

$T_{c}+\Delta D=1.7 T_{p}$

Using the above relationship we get

$\Delta D=0.133 T_{c}$

Substituting equation (21) in equation (19), we get

$q_{p}=\frac{726 A Q}{T_{c}}$

Equation (22) is used in the analytical model HEC-HMS program to generate the peak discharge. 


\subsubsection{Infiltration Loss Method (SCS Method)}

The Soil Conservation Service (SCS, now known as the Natural Resources Conservation Service) method was originally based on the observed runoff from agricultural watersheds. As this method was applied on a more frequent basis to urban areas, the SCS developed additional guidance for using the method on urban areas, which have impervious surfaces.

The SCS method uses a Curve Number to define some of the characteristics of the watershed. This Curve Number reflects a combination of the soil hydrologic group, the land use, and the treatment class. This combination of items used in determination of the Curve Number is referred to as the hydrological soil-cover complex. The Curve Number, based on the hydrological soil-cover complex, is used to determine the runoff volume resulting from given rainfall. One item that most affects the soil-cover complex is the hydrological characteristic of the soil itself. 


\subsubsection{Soil Classification}

Over 4,000 soils have been classified by the SCS into four distinct hydrologic groups: A, B, C or D. The SCS National Engineering Handbook, Section 4, listed in the references, contains a complete listing of the soil names and each soil's hydrologic group. These hydrologic groups are based on the infiltration capacity of each soil and are defined in Table 3.1.

Table 3.1 - Description Of Hydrologic Soil Groups (USDA SCS, 1985).

\begin{tabular}{cl}
\hline $\begin{array}{c}\text { Soil } \\
\text { Group }\end{array}$ & Description \\
\hline A & These soils have low runoff potential and high infiltration rates even when \\
& thoroughly wetted. They consist chiefly of deep, well to excessively drained \\
& sand or gravel and have a high rate of water transmission (greater than 0.30 \\
& in/hr). \\
B $\quad$ These soils have moderate infiltration rates when thoroughly wetted and consist \\
chiefly of moderately deep to deep, moderately well to well drained soils with \\
moderately fine to moderately coarse textures. These soils have a moderate rate \\
of water transmission (0.15-0.30 in/hr). \\
These soils have low infiltration rates when thoroughly wetted and consist \\
chiefly of soils with a layer that impedes downward movement of water and \\
soils with moderately fine to fine texture. These soils have a low rate of water \\
transmission (0.05-0.15 in/hr). \\
These soils have high runoff potential. They have very low infiltration rates \\
when thoroughly wetted and consist chiefly of clay soils with a high swelling \\
potential, soils with a permanent high water table, soils with a claypan or clay \\
layer at or near the surface, and shallow soils over nearly impervious material. \\
These soils have a very low rate of water transmission (0-0.05 in/hr).
\end{tabular}

Arc View GIS soil shape files was digitized from the Soil Survey for Tucker County, West Virginia, by the West Virginia University Natural Resources Analysis Center (WVU NRAC); and all the soils types present in the Beaver Creek watershed were classified into their respective hydrologic group (A, B, C, or D) using the USDA SCS 
(1985, 1993a) classification. Table 3.2 and Figure 3.3 list the hydrologic classification of the Beaver Creek watershed soils.

Table 3.2 - Hydrologic Classification Of Beaver Creek Watershed Soils.

\begin{tabular}{|c|c|c|}
\hline Soil Symbol & Soil Type & $\begin{array}{l}\text { Hydrologic } \\
\text { Group }\end{array}$ \\
\hline At & Atkins silt loam & $\mathrm{D}$ \\
\hline $\mathrm{Bc}$ & Barbour and Pope gravelly sandy loam & B \\
\hline Bo & Blago silty clay loam & $\mathrm{D}$ \\
\hline Bp & Blago silt loam, overflow & $\mathrm{D}$ \\
\hline BrA & Brinkerton silt loam (0-3\% slopes) & $\mathrm{D}$ \\
\hline $\mathrm{BrB}$ & Brinkerton silt loam(3-8\% slopes) & $\mathrm{D}$ \\
\hline $\mathrm{BrC}$ & Brinkerton silt loam ( $8-15 \%$ slopes) & $\mathrm{D}$ \\
\hline $\mathrm{BsC}$ & Brinkerton and Nolo extremely stony soils ( $3-15 \%$ slopes) & $\mathrm{D}$ \\
\hline $\mathrm{CoB}$ & Cookport silt loam(2-10\% slopes) & $\mathrm{C}$ \\
\hline $\mathrm{DaB}$ & Dekalb chanery loam (3-10\% slopes) & $\mathrm{C}$ \\
\hline $\mathrm{DaC}$ & Dekalb chanery loam (10-20\% slopes) & $\mathrm{C}$ \\
\hline $\mathrm{DaD}$ & Dekalb chanery loam (20-30\% slopes) & $\mathrm{C}$ \\
\hline DkB & Dekalb loam (3-10\% slopes) & $\mathrm{C}$ \\
\hline $\mathrm{DkC}$ & Dekalb loam (10-20\% slopes) & $\mathrm{C}$ \\
\hline $\mathrm{DmC}$ & Dekalb extremely stony loam (3-20\% slopes) & $\mathrm{C}$ \\
\hline DmE & Dekalb extremely stony loam (20-40\% slopes) & $\mathrm{C}$ \\
\hline $\mathrm{DmF}$ & Dekalb extremely stony loam (40-70\% slopes) & $\mathrm{C}$ \\
\hline EnB & Ernest silt loam (3-8\%slopes) & $\mathrm{C}$ \\
\hline $\mathrm{EnC}$ & Ernest silt loam (8-15\%slopes) & $\mathrm{C}$ \\
\hline $\mathrm{ErC}$ & Ernest extremely stony silt loam (3-15\%slopes) & $\mathrm{C}$ \\
\hline $\mathrm{LcC}$ & Leetonia channnery loam (10-20\%slopes) & $\mathrm{C}$ \\
\hline LdA & Lickdale silt loam (0-5\%slopes) & $\mathrm{D}$ \\
\hline LsA & Lickdale very stony silt loam ( $0-5 \%$ slopes $)$ & $\mathrm{D}$ \\
\hline $\mathrm{Mp}$ & Muck and Peat & $\mathrm{D}$ \\
\hline NoA & Nolo silt loam (0-5\% slopes) & $\mathrm{D}$ \\
\hline NoB & Nolo silt loam (5-10\% slopes) & $\mathrm{D}$ \\
\hline $\mathrm{Ph}$ & Philo silt loam & B \\
\hline $\mathrm{Sa}$ & Sandstone rubble land & $\mathrm{D}$ \\
\hline $\mathrm{Sm}$ & Strip mine & $\mathrm{D}$ \\
\hline Ту & Tyler silt loam & $\mathrm{D}$ \\
\hline $\mathrm{Vb}$ & Very stony land-Brinkerton-Lickdale association & $\mathrm{D}$ \\
\hline VdE & Very stony land-Dekalb complex ( $20-40 \%$ slopes) & $\mathrm{C}$ \\
\hline $\mathrm{VdF}$ & Very stony land-Dekalb complex ( $40-80 \%$ slopes) & $\mathrm{C}$ \\
\hline $\mathrm{VeC}$ & Very stony land-Ernest complex (3-15\% slopes) & $\mathrm{C}$ \\
\hline $\mathrm{VlC}$ & Very stony land-Leetonia complex (3-20\% slopes) & $\mathrm{C}$ \\
\hline W & Wet terrace land & $\mathrm{D}$ \\
\hline
\end{tabular}




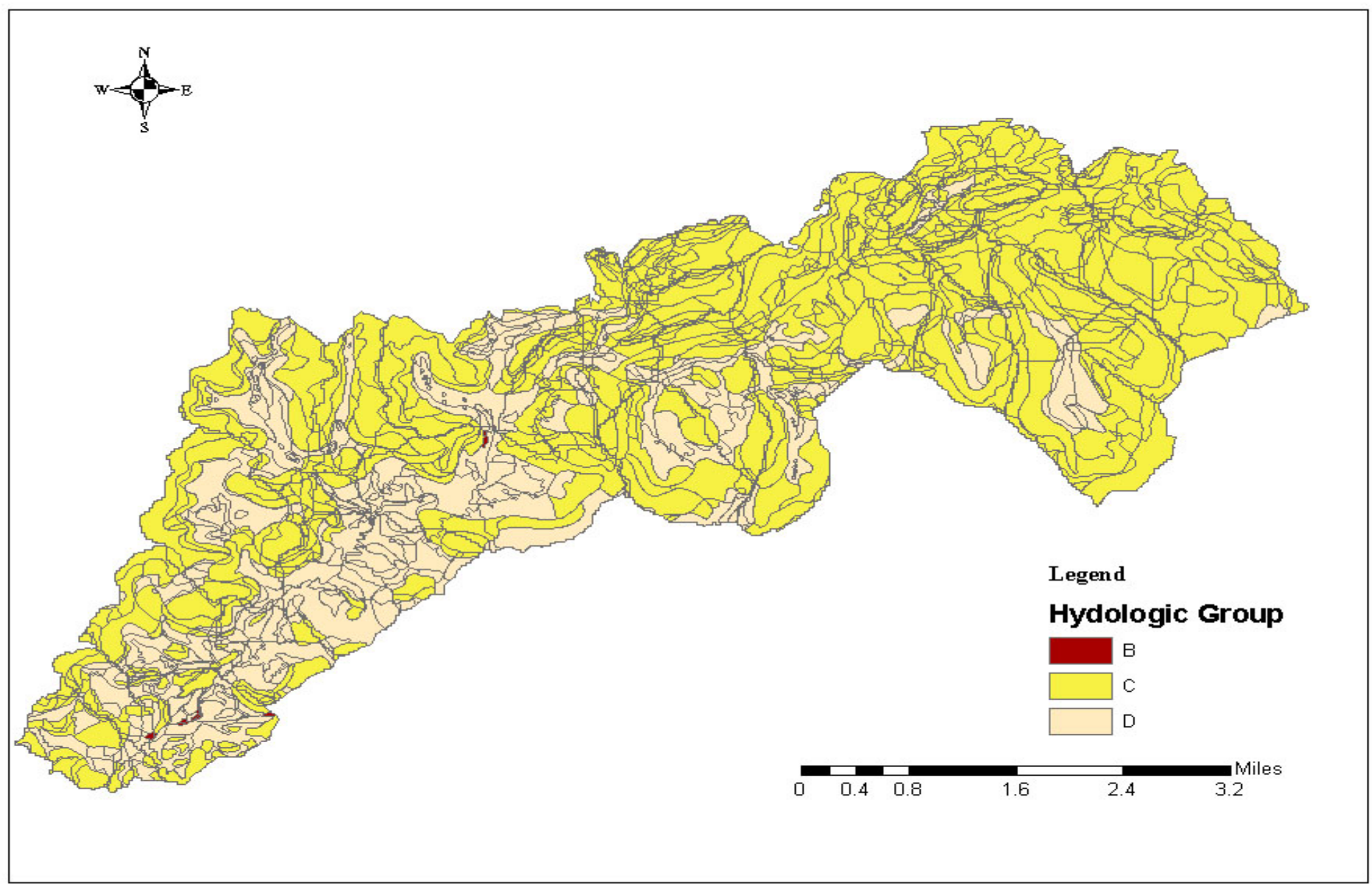

Figure 3.3 - Hydrologic Classification Of Beaver Creek Watershed Soils. 


\subsubsection{Curve Number}

As briefly mentioned earlier, the SCS Method uses a Curve Number (CN) for numerical definition of the soil-cover complex for a defined drainage area. Curve Number is a parameter defined by the NRCS to represent the transformation of rainfall to runoff. The soil hydrological group, the percentage of impervious cover, the condition of vegetative cover and the antecedent moisture condition define the selection of a Curve Number.

The impervious cover in a watershed includes roofs, sidewalks, paved driveways, paved streets, paved alleys and paved parking areas. Impervious surfaces in a large watershed are usually included in a composite Curve Number for the entire watershed.

The condition of the vegetative cover in unpaved areas has an effect on the volume and rate of runoff from a watershed. The SCS has qualitatively defined vegetative cover as poor, fair or good condition relative to the percentage of ground cover. These qualitative terms are defined below.

Poor: Less than 50 percent ground cover; heavily grazed with no plant litter.

Fair: 50 to 75 percent ground cover; not heavily grazed, some plant litter.

Good: Greater than 75 percent ground cover; lightly or occasionally grazed.

Finally, the Antecedent Runoff Condition (ARC) affects the Curve Number value. The ARC is descriptive of the precipitation received on the design watershed prior to the design storm event. As most designers know, the more saturated a soil is prior to a storm event, then the greater the runoff volume and peak discharge that can be expected. The NRCS presently uses the ARC II conditions for which the Curve Number's are based on the average conditions. 
Table 3.3 lists Curve Numbers by land covers that specifically apply to Beaver Creek and that were determined using Arc View GIS shape files digitized from the soil survey for Tucker County, West Virginia, by the West Virginia University Natural Resources Analysis Center (WVU NRAC). Figure 3.4 shows the different land cover types of the Beaver Creek watershed.

Table 3.3 - Runoff Curve Numbers For Hydrologic Soil-Cover Complexes Of Beaver Creek Watershed.

\begin{tabular}{cccccc}
\hline Land & Lover & Land Cover & \multicolumn{4}{c}{ Curve Number for } \\
Symbol & Description & A & B & C & D \\
\cline { 3 - 6 } & Wetlands & 100 & 100 & 100 & 100 \\
POW & Herbaceous & 30 & 58 & 71 & 78 \\
PEM1 & Forested, broad-leaved decidous & 30 & 55 & 70 & 77 \\
PFO1 & Forested, needle-leaved evergreen & 30 & 55 & 70 & 77 \\
PFO4 & Forested, dead & 30 & 58 & 71 & 78 \\
PFO5 & Forested, mixed & 30 & 55 & 70 & 77 \\
PFO8 & Moss & 35 & 56 & 70 & 77 \\
PML1 & Streets and roads paved with open ditches & 83 & 89 & 92 & 93 \\
Road & Scrub/shrub, broad-leaved decidous & 35 & 56 & 70 & 77 \\
PSS1 & Scrub/shrub, needle-leaved evergreen & 35 & 56 & 70 & 77 \\
PSS4 & Scrub/shrub, dead 30 58 71 78 & 30 & 58 & 71 & 78 \\
PSS5 & Artificial cover, lawns, farmsteads & 59 & 74 & 82 & 86 \\
UAA & Forested, broad-leaved decidous & 30 & 55 & 70 & 77 \\
UFO1 & Forested, needle-leaved evergreen & 30 & 55 & 70 & 77 \\
UFO4 & Forested, mixed & 30 & 55 & 70 & 77 \\
UFO8 & Herbaceous & 30 & 58 & 71 & 78 \\
UHU & Scrub/shrub, mixed & 35 & 56 & 70 & 77 \\
USS1 & Scrub/shrub, broad-leaved decidous & 35 & 56 & 70 & 77 \\
USS4 & Scrub/shrub, needle-leaved evergreen & 35 & 56 & 70 & 77 \\
USS8 & Water bodies, lakes, ponds & 100 & 100 & 100 & 100 \\
UUV & & & & & \\
water & & 59 & 74 & 82 & 86 \\
\hline
\end{tabular}




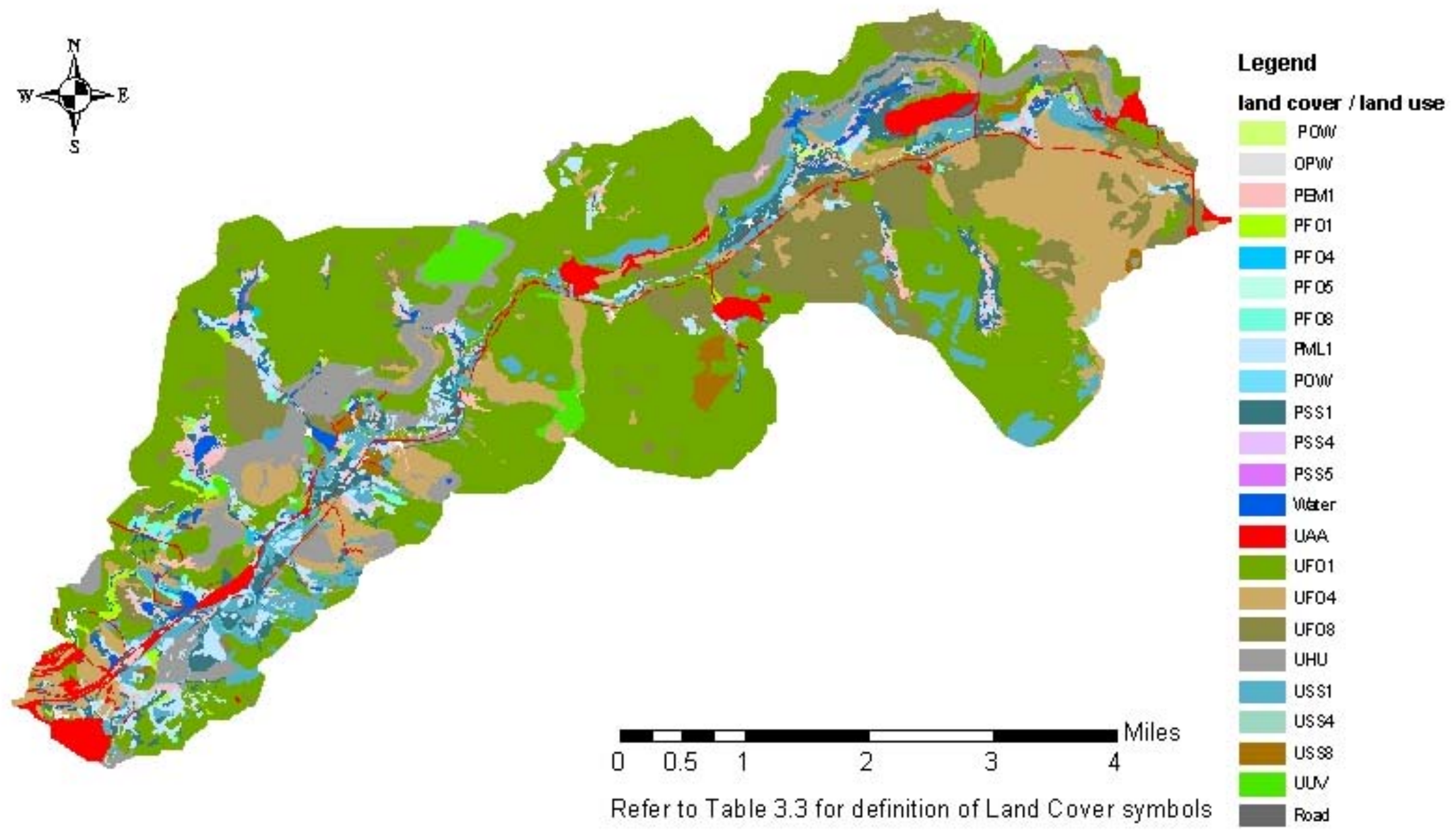

Figure 3.4 - Land Cover Types Of Beaver Creek Watershed. 


\subsubsection{Rainfall-Runoff Relationship}

The Soil Conservation Service has developed a rainfall-runoff relationship to calculate the total runoff volume for a single storm. The volume of runoff depends on the volume of precipitation and the volume of storage that is available for retention. The actual retention is the difference between the volumes of precipitation and runoff. Furthermore, a certain volume of the precipitation at the beginning of the storm will not appear as runoff and this volume is called the initial abstraction. The SCS developed the following rainfall-runoff relation, which is also shown schematically in Figure 3.5.

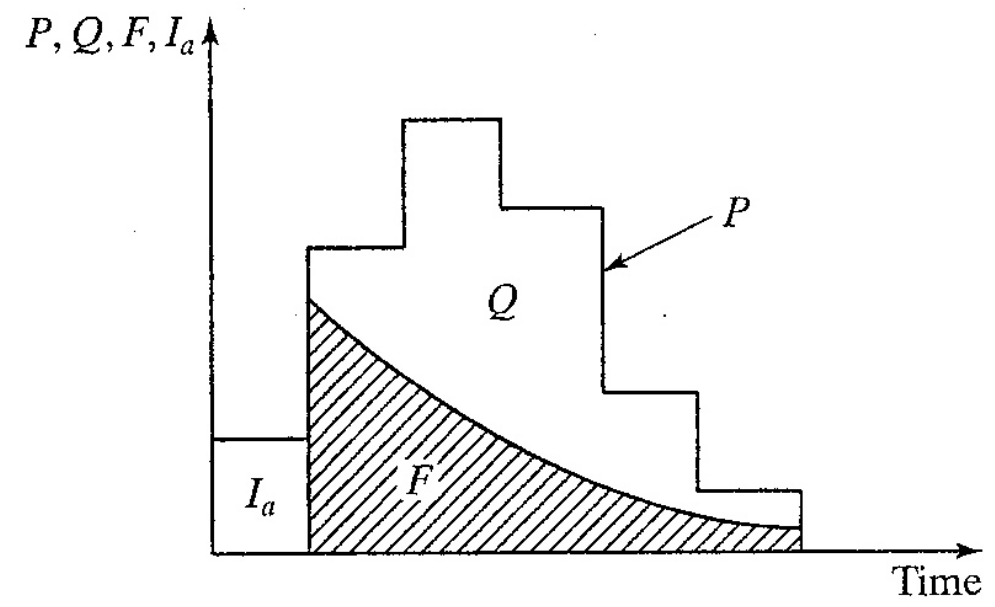

Figure 3.5 - Relationship Between Precipitation, Infiltration And Runoff (McCuen, 1998).

$$
\frac{F}{S}=\frac{Q}{P-I_{a}} \quad \text { for } P>I_{a}
$$

Where,

$F$ - Actual retention;

$S$ - Potential maximum retention ( $S$ is equal to or greater than $F$ );

$Q$-Actual runoff volume;

$P$ - Precipitation as rainfall ( $P$ is equal to or greater than $Q$ ); and

$I_{a}$ - Initial abstraction;

The actual retention $\mathrm{F}$ when the initial abstraction $I_{a}$ is considered is:

$F=\left(P-I_{a}\right)-Q$ 
Substituting Equation (24) into Equation (23) yields the following:

$$
\frac{Q}{\left(P-I_{a}\right)}=\frac{\left(P-I_{a}\right)-Q}{S}
$$

Rearranging Equation (25) to solve for $Q$ results in:

$$
Q=\frac{\left(P-I_{a}\right)^{2}}{\left(P-I_{a}\right)+S}
$$

Initial abstractions $I_{a}$ are water losses (such as plant interception, infiltration, and surface storage) which occur prior to runoff and are thus subtracted from the total rainfall available for either soil retention or quick response (USDA-SCS, 1985). The initial abstraction $I_{a}$ is a function of land use, treatment and condition; interception; infiltration; depression storage; and antecedent soil moisture. An empirical analysis was performed by the SCS for the development of the rainfall-runoff relation, and the following formula was found to be best for estimating $I_{a}$ :

$I_{a}=0.2 S$

Research performed by the Soil Conservation Service since the development of Equation (27) has suggested that Equation (27) may not be correct under all circumstances. The initial abstraction ratio, $I_{d} / S=0.2$ was based on watershed measurements with a large degree of variability. Other researchers have reported using values ranging from 0.0 to 0.5 (USDA-SCS, 1985; Ponce and Hawkins, 1996). The original estimates of $I_{a}$ were determined by subtracting rain that fell prior to the beginning of watershed outlet response from the total rainfall (USDA-SCS, 1985). Hawkins (2002) investigated the abstraction ratio using event rainfall data from several hundred plots and suggested a value of 0.05 in place of the customary 0.2 to be more appropriate for use in runoff calculations involving lower rainfall depths or lower CN's.

However, the initial abstraction ratio of 0.2 remains in use until the SCS performs and accepts a more comprehensive study. It is important to note that Equation (27) implies that the factors affecting $I_{a}$ would also affect $S$. The relative difference in runoff, using the Curve Numbers and event rainfall for this study, shows a difference of only $2-3 \%$. Hence, initial abstraction ratio of 0.2 is used for this study. Substituting Equation (27) into Equation (26) yields: 


$$
\begin{array}{ll}
Q=\frac{(P-0.2 S)^{2}}{(P+0.8 S)} & \text { for } P>0.2 S \\
Q=0 & \text { for } P<0.2 S
\end{array}
$$

While Equation (26) has two unknowns, $I_{a}$ and $S$, Equation (28) has been reduced to an equation with one unknown; $S$. From the definition of Curve Number, $S$ can be estimated by:

$$
S=\frac{1000}{C N}-10
$$

where;

$C N$ - Soil-cover complex Curve Number; and

$S$ - Potential maximum retention [inches]

Thus, the rainfall relationship of Equation (28), which has one unknown, has been replaced with another relationship with one unknown, $C N$. The runoff volume can be determined as a function of precipitation volume and Curve Number. The SCS has prepared rainfall versus runoff curves. With a known Curve Number and the design rainfall, then the direct runoff can be read from these curves.

\subsubsection{Time Of Concentration}

Travel time is a component of the time of concentration. There are various theories explaining the time of concentration. Time of concentration is the time required, with uniform rain, for $100 \%$ of the tract of land to contribute to the direct runoff at the outlet (Viessman, 2002). It is hence, the time the time required for rain falling at the hydraulically most remote location in the watershed to reach the outlet. It is also the time taken by a wave to travel from the most remote point of the watershed after cessation of rainfall (Viessman, 2002). Time of concentration influences the shape and peak of the runoff hydrograph. It is also defined as the time from the end of excess rainfall to the inflection point on the recession limb of the unit hydrograph. Time of concentration cannot be subject to direct measurement since it is somewhat abstract. Estimates of time of concentration are approximate and require subjective judgment. 
The time of concentration may be estimated as the sum of all travel times for consecutive segments of flow (USDA SCS, 1986). Time of concentration can be estimated as:

$T_{c}=T_{\text {sheet }}+T_{\text {shallow }}+T_{\text {channel }}$

$T_{\text {sheet }}$ - Sum of travel time in sheet flow segments over the watershed land surface;

The SCS suggests that the sheet flow travel time can be estimated by:

$T_{\text {sheet }}=\frac{0.007\left(N L_{s}\right)^{0.8}}{\left(P_{2}\right)^{0.5} S_{g}^{0.4}}$

where,

$N$ - An overland-flow roughness coefficient;

$L_{S}$ - Flow length;

$P_{2}$ - 2-year, 24-hour rainfall depth, in inches; and

$S_{g}$ - Slope of hydraulic grade line, which may be approximated by the land slope.

The overland flow roughness coefficient, according to (USACE, 1998a) is given in Table 3.4

Table 3.4 - Overland-Flow Roughness Coefficients For Sheet-Flow Modeling (USACE, 1998a).

\begin{tabular}{|c|c|}
\hline Surface description & $\mathrm{N}$ \\
\hline Fallow (no residue) & 0.011 \\
\hline \multicolumn{2}{|l|}{ Cultivated soils: } \\
\hline - Residue cover $\leq 20 \%$ & 0.06 \\
\hline - $\quad$ Residue cover $\geq 20 \%$ & 0.17 \\
\hline \multicolumn{2}{|l|}{ Grass: } \\
\hline - Short grass prairie & 0.15 \\
\hline - Dense grass & 0.24 \\
\hline - Bermuda grass & 0.41 \\
\hline Range & 0.13 \\
\hline \multicolumn{2}{|l|}{ Woods: } \\
\hline - Light underbrush & 0.40 \\
\hline - Dense underbrush & 0.80 \\
\hline
\end{tabular}


Sheet flow usually changes to shallow concentrated flow after about 50 feet in Beaver Creek watershed.

$T_{\text {shallow }}$ - Sum of travel time in shallow flow segments or in shallow rills and rivulets

The average velocity for shallow concentrated flow can be estimated as:

$$
V_{s c}=\left\{\begin{array}{ll}
16.13 \sqrt{S_{l}} & \text { for unpaved surface } \\
20.33 \sqrt{S_{l}} & \text { for paved surface }
\end{array}\right\} \quad \text { (USDA SCS, 1986) }
$$

$S_{l}$ may be approximated as the land slope.

Once velocity is estimated, travel time can easily be computed as:

$$
T_{\text {shallow }}=\frac{L_{s c}}{V_{s c}}
$$

where,

$L_{s c}$ - Channel length in shallow concentrated section

The remaining part of the flow is the channel flow.

$T_{\text {channel }}$ - Sum of travel time in channel segments.

The length of the channels; $L_{c}$ can be approximated from field surveys, maps, or aerial photographs or by the blue lines indicated as streams on USGS quadrangle maps. For these channels, an estimate of the velocity can be obtained with the Manning's equation as:

$$
V_{c}=\frac{C R^{2 / 3} S_{e}^{1 / 2}}{n}
$$

where,

$V_{c}$ - Average velocity;

$R$ - Hydraulic radius (ratio of channel cross-section area to wetted perimeter);

$S_{e}$ - Slope of the energy grade line (often approximated as channel bed slope);

$C$ - Conversion constant (1.00 for SI and 1.49 for US customary units); and

$n$ - Commonly known as Manning's roughness coefficient.

The estimate of Manning's roughness coefficient was done by "visual comparison". The Manning's $n$ pictorial as supplied by USGS Water Supply Paper No. 1849 (Barnes, 1967) and Roughness Characteristics of New Zealand Rivers (Hicks \& Mason, 1998) were used to estimate $n$ by visual resemblance. 
Once velocity is estimated, channel travel time is computed as:

$T_{\text {channel }}=\frac{L_{c}}{V_{c}}$

Alternatively, many empirical formulae have been developed to estimate the time of concentration. The SCS also provides an equation to estimate the watershed time of concentration using the Curve Number, for drainage area less than 2000 acres $(3.125$ $\left.\mathrm{mi}^{2}\right)$.

$T_{c}=\frac{1.67 L_{f}^{0.8}[(1000 / C N)-9]^{0.7}}{1900 S^{0.5}}$

where,

$L_{f}$ - Hydraulic length of the watershed (longest flow path) in feet;

$S$ - Average watershed slope along flow path in \%; and

$C N$ - SCS runoff Curve Number.

The SCS CN equation for time of concentration was developed from agricultural watershed data with a broad set of conditions ranging from heavily forested watersheds with steep channels and a high percent of the runoff resulting from subsurface and meadows, providing retardance to surface runoff, to smooth land surface and large paved parking areas (Kent, 1972). The Beaver Creek watershed falls well within this set of conditions and therefore Equation (38) can be used in the analysis.

Determination of the time of concentration by one method has watershed characteristics that may be omitted in other method. It is therefore good to consider more than one method and choose the one that best fits the characteristics of a given watershed. 


\subsubsection{Baseflow}

Subsurface flow from groundwater or springs usually accounts for flow in a channel during extended periods of little or no rainfall. This component of the stream discharge is termed baseflow. During a storm event, this baseflow component may increase due to the increased infiltration to the saturated zone. For baseflow streams, the amount of groundwater discharge is directly proportional to the hydraulic gradient towards the stream (Fetter, 2001). During large storm events, the peak discharge is slightly affected by the baseflow.

Several techniques are used to separate the total runoff hydrograph's direct surface runoff and baseflow components. Baseflow separation was performed with the help of a Windows compatible program HydroSep Beta 1.5 written by Mike Sawada, University of Ottawa, Canada. It is available free on the internet at:

http://www.uottawa.ca/academic/arts/geographie/lpcweb/newlook/data_and_downloads/d ownload/sawsoft/hydrosep.htm

The program uses a simple method of baseflow separation where the overland flow is assumed to end at some fixed time ( $D_{y}$ days) after the storm peak (Fetter, 2001).

$D_{y}=A^{0.2}$

where,

$D_{y}$ - Number of days between the storm peak and the end of overland flow; and $A$ - Drainage area in square miles.

Here, the initial recession curve is projected forward until it lies directly below the peak rate of flow. It is then projected forward on to the recession limb of the hydrograph at the point $D_{y}$ days after the peak. The area below these two straight lines gives the amount of baseflow (Figure 3.6). 


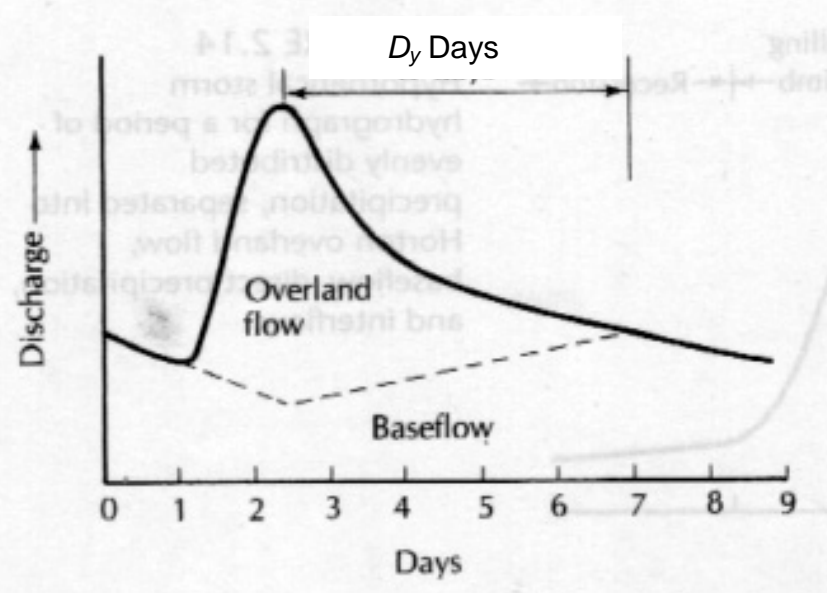

Figure 3.6 Hydrograph Separation Into Overland Flow And Baseflow Components (Fetter, 2001).

The Beaver Creek watershed is not gaged. The nearest gaging station is the Blackwater River USGS gage (0306600) at Davis, WV. The monthly mean stream flows are available for this gaging station from 1921 to 2001. The HEC-HMS model requires a constant monthly baseflow for each of the sub-basins to generate the peak discharges. An area-weighted estimate was used to calculate the baseflow for the Beaver Creek subbasins using the baseflow derived from the USGS stream gage (03066000), at Davis, $\mathrm{WV}$, on the Blackwater River.

The last five years of monthly stream records were used in the HydroSep program to estimate the average percentage of baseflow for each month (January to December). These average percentages of baseflow were used to calculate the areaweighted baseflow for the sub-basins used in this study. Table 3.5 lists the average monthly baseflow used in the HEC-HMS program for the Beaver Creek watershed. The soil of the Beaver Creek watershed mainly consists of hydrologic groups C and D having slow to very slow infiltration and water transmission rates, and subsurface flow is not dominant. These area-weighted estimates of the baseflow for the Beaver Creek watershed are considered acceptable since the baseflow is very small compared to the total peak discharges. The percentage of baseflow to the 1-year peak discharge varied from $0.05 \%$ to $1.1 \%$ for the smallest sub-basin $\left(0.04 \mathrm{mi}^{2}\right)$ and $4.0 \%$ to $19.8 \%$ for the largest sub-basin $\left(22.2 \mathrm{mi}^{2}\right)$. 
Table 3.5 - Average Monthly Baseflow For Different Sub-Basins Of Beaver Creek Watershed.

\begin{tabular}{|c|c|c|c|c|c|c|c|c|c|c|c|c|c|}
\hline \multirow{2}{*}{$\begin{array}{c}\text { Sub- } \\
\text { basin } \\
\text { identity }\end{array}$} & \multirow{2}{*}{$\begin{array}{l}\text { Drainage } \\
\text { Area } \\
\left(\mathbf{m i}^{2}\right)\end{array}$} & \multicolumn{12}{|c|}{ Baseflow (cfs) } \\
\hline & & Jan & Feb & Mar & Apr & May & Jun & Jul & Aug & Sep & Oct & Nov & Dec \\
\hline $\begin{array}{l}3066000 \\
\text { (USGS) }\end{array}$ & 85.900 & 202.84 & 288.43 & 306.70 & 238.43 & 149.41 & 120.91 & 58.91 & 95.45 & 62.81 & 95.29 & 145.62 & 210.45 \\
\hline MTB1 & 0.040 & 0.09 & 0.13 & 0.14 & 0.11 & 0.07 & 0.06 & 0.03 & 0.04 & 0.03 & 0.04 & 0.07 & 0.10 \\
\hline MTB2 & 0.059 & 0.14 & 0.20 & 0.21 & 0.16 & 0.10 & 0.08 & 0.04 & 0.07 & 0.04 & 0.07 & 0.10 & 0.14 \\
\hline MTB4 & 0.065 & 0.15 & 0.22 & 0.23 & 0.18 & 0.11 & 0.09 & 0.04 & 0.07 & 0.05 & 0.07 & 0.11 & 0.16 \\
\hline NMTB1 & 0.327 & 0.77 & 1.10 & 1.17 & 0.91 & 0.57 & 0.46 & 0.22 & 0.36 & 0.24 & 0.36 & 0.55 & 0.80 \\
\hline NMTB2 & 0.426 & 1.01 & 1.43 & 1.52 & 1.18 & 0.74 & 0.60 & 0.29 & 0.47 & 0.31 & 0.47 & 0.72 & 1.04 \\
\hline NMTB3 & 0.918 & 2.17 & 3.08 & 3.28 & 2.55 & 1.60 & 1.29 & 0.63 & 1.02 & 0.67 & 1.02 & 1.56 & 2.25 \\
\hline LBCB & 22.176 & 52.37 & 74.46 & 79.18 & 61.55 & 38.57 & 31.21 & 15.21 & 24.64 & 16.21 & 24.60 & 37.59 & 54.33 \\
\hline
\end{tabular}




\subsection{Methodology}

The analysis of the Beaver Creek mineland and non-mineland tributaries began with the selection and survey of the study reaches. A longitudinal section close to 20 times the width of the channel was chosen as the study reach. Each study reach included a minimum of one cross-section having readily identified bankfull features, preferably at a riffle section as recommended by Rosgen (1996). Once the study reach was selected, cross-section locations and survey instrument set-up locations were identified. The location of the survey reach was recorded with the help of a GPS unit in order to correlate the location with respect to aerial photographs and maps.

Bankfull indicators vary from stream to stream. The active floodplain is the flat, depositional surface adjacent to many stream channels, and is the best indicator of bankfull stage. Floodplains are most prominent along low-gradient, meandering reaches. A bankfull indicator may not be on both sides of the channel and may be found on just one side of meander bends. They are often hard or impossible to identify along steeper mountain streams. Hence, most of the surveys were done in the reaches close to Route 93 where the gradients are less, allowing a more reliable identification of bankfull stage. This was also to help delineate the watershed basin with respect to the Route 93, a local route that runs mostly parallel to Beaver Creek from Davis to Mount Storm Lake. Most of the tributaries cross Route 93 perpendicularly to join the Beaver Creek.

In addition to the identified bankfull cross-sections, several additional crosssections were selected at regular intervals along each study reach. Each cross-section was surveyed to measure all significant breaks in slope, left and right water's edge, and important bank and floodplain features. Cross-section lengths were approximately two times the maximum channel depth at bankfull flow.

Where floodplains were absent or poorly defined, other indicators was used to identify bankfull stage. The importance of specific indicators varies with stream type. Efforts were made to include several bankfull indicators to support identification of the bankfull stage. The other useful indicators included in this study were:

- The height of depositional features (especially the top of the point bar, which defines the lowest possible level for bankfull stage);

- Slope or topographic breaks along the bank; and 
- Change in vegetation.

For this study, 4 tributaries on mineland spoils, 4 tributaries not on mineland spoils, and 2 locations along Beaver Creek were chosen in order to have a mixed set of data. This mixed set of data allows us a better understanding of the watershed and also provides information by which to determine whether the geomorphic and hydraulic characteristics of streams coming from mineland spoils are different from other streams in the Beaver Creek watershed.

The Beaver Creek watershed delineation was done using Digital Elevation Models (DEM), which consists of elevations measured on a $30 \mathrm{~m}$ x $30 \mathrm{~m}$ grid. The DEM for Davis and Mount Storm Lake was imported into the Arc GIS program and the 'hydrologic modeling' tool was utilized to identify the flow directions and 'flow accumulation' lines. The 'flow accumulation' lines denote the streams in the watershed. These were matched with aerial photographs. Identifying a point in any of streams generated in the DEM gives the boundary of the watershed upstream of the point of interest. The sub-basins were then converted into polygons from which the geometric data (drainage area, slopes, runoff distances, and coordinates) were computed. The $30 \mathrm{~m}$ x $30 \mathrm{~m}$ grid resolution was not good enough to delineate the watershed for the small subbasins. Hence, a 10-ft contour interval map was imported into the Arc GIS program. Streams were identified on this map and ridges and valleys were used to delineate the boundaries for the sub-basins.

Table 3.6 lists some key parameters used in the hydraulic and hydrologic calculations. The Manning's roughness coefficients listed in Table 3.6 are the final values used in this study, which were estimated by "visual comparison" approach (Barnes, 1967 and Hicks, 1998). Table 3.6 also lists the geometric data and Curve Numbers for each sub-basin. 
Table 3.6 - Hydrological Features Of The Sub-basins And Tributaries.

\begin{tabular}{ccccccc}
\hline $\begin{array}{c}\text { Sub-basin } \\
\text { identity }\end{array}$ & $\begin{array}{c}\text { Area } \\
\mathbf{( m i}^{2} \mathbf{)}\end{array}$ & $\begin{array}{c}\text { Av. Basin } \\
\text { slope } \\
\text { (ft/ft) }\end{array}$ & $\begin{array}{c}\text { Curve } \\
\text { Number }\end{array}$ & $\begin{array}{c}\text { Total } \\
\text { Channel } \\
\text { Length } \\
\text { (ft) }\end{array}$ & \multicolumn{2}{c}{ Manning's n } \\
\hline MTB1 & 0.040 & 0.0699 & 73 & 3004 & 0.025 & 0.03 \\
MTB2 & 0.059 & 0.0581 & 77 & 3961 & 0.03 & 0.035 \\
MTB3 & 0.059 & 0.0842 & 75 & 3681 & 0.025 & 0.03 \\
MTB4 & 0.065 & 0.0585 & 73 & 3845 & 0.036 & 0.03 \\
NMTB1 & 0.327 & 0.0317 & 75 & 7574 & 0.055 & 0.06 \\
NMTB2 & 0.426 & 0.0209 & 77 & 8603 & 0.055 & 0.06 \\
NMTB3 & 0.918 & 0.0598 & 73 & 9768 & 0.04 & 0.05 \\
UBCB & 1.425 & 0.0349 & 71 & 12902 & 0.035 & 0.04 \\
NMTB4 & 1.971 & 0.0159 & 73 & 13544 & 0.035 & 0.05 \\
LBCB & 22.176 & 0.0074 & 74 & 99619 & 0.04 & 0.045 \\
\hline
\end{tabular}

The digitized soil shape files and the digitized land use / land cover shape file were superimposed on the delineated sub-basins of the Beaver Creek watershed in the Arc GIS program. The 'geo-processing' tool within the Arc GIS program was used to generate area-weighted estimates of land use / land cover and soil types within the polygons (delineated sub-basins), which were then analyzed to generate the areaweighted Curve Numbers for the sub-basins.

Since there are no gaging stations available for any streams in the Beaver Creek watershed, numerical models had to be relied upon for development of geomorphic relationships. The channel cross-sections were fed into the HEC-RAS model and various flows were simulated to match the water stage elevation with the observed bankfull elevation to get the bankfull flow for the reach. Empirical equations and curves were generated that provided bankfull flowrate, cross-sectional area, width and depth as functions of drainage area. These are discussed in the following chapters.

Determination of the bankfull recurrence interval for the Beaver Creek watershed was done with the help of regional regression equations for rural, unregulated streams in West 
Virginia (Wiley et al. 2002) and a hydrologic model (HEC-HMS). Peak discharges were calculated using the regional regression equations developed by Wiley et al. (2002) for recurrence intervals between 1.1 and 3.0 years. Recurrence interval was determined on the basis of the peak discharge obtained by the equations that was closest to the bankfull flow (obtained from HEC-RAS). Regional regression equations could not be used for drainage area less than $0.22 \mathrm{mi}^{2}$ and larger than $1486 \mathrm{mi}^{2}$. For sub-basins with drainage area less than $0.22 \mathrm{mi}^{2}$, HEC-HMS was used to calculate the peak flows for return periods of 1, 2 and 5 years. The peak discharges obtained from the HEC-HMS analysis for return periods of 1,2 , and 5 years were then interpolated to get the recurrence interval for the bankfull discharge determined using HEC-RAS. 


\subsection{The Study Site}

The Beaver Creek watershed is located in Tucker County West Virginia, north of the Brown Mountains and south of Dobbins Ridge in the Allegheny front of the Appalachians. Beaver Creek joins the Blackwater River near the town of Davis. Geographically the study site falls on the eastern side of the continental divide. The Beaver Creek watershed has been investigated by researchers at the Department of Civil and Environmental Engineering (CEE) at West Virginia University as part of a research project funded by West Virginia Division of Highways (WVDOH). The watershed is highly impacted by historical mining activities and mine spoils which produce acid mine drainage (AMD). Researchers have focused on the chemical analysis of Beaver Creek (Hudnall, 2003) and hydrologic modeling of the watershed (Tummala, 2003) to aid in the design of passive treatment facilities and stream restoration. The proposed alignment of the Corridor $H$ from Davis to Bismarck, West Virginia, passes through this watershed and across the reclaimed mineland and some mineland streams. Due to the alignment, some of these streams will be disturbed from their natural courses and will be realigned. Some of these streams come out of the mine spoils and are still evolving; they are not stable. The availability of discharge data from the Davis gaging station is inadequate to predict the runoff hydrographs on Beaver Creek; therefore, rainfall-runoff models that do not require calibration with gage data were used to predict the flows at various locations in the watershed. The location of the Beaver Creek watershed in the state of West Virginia is shown in Figure 3.7. A map of the watershed and location of the streams selected for this study is presented in Figure 3.8. A detailed description of each study reach and its basin is given in the following section. 

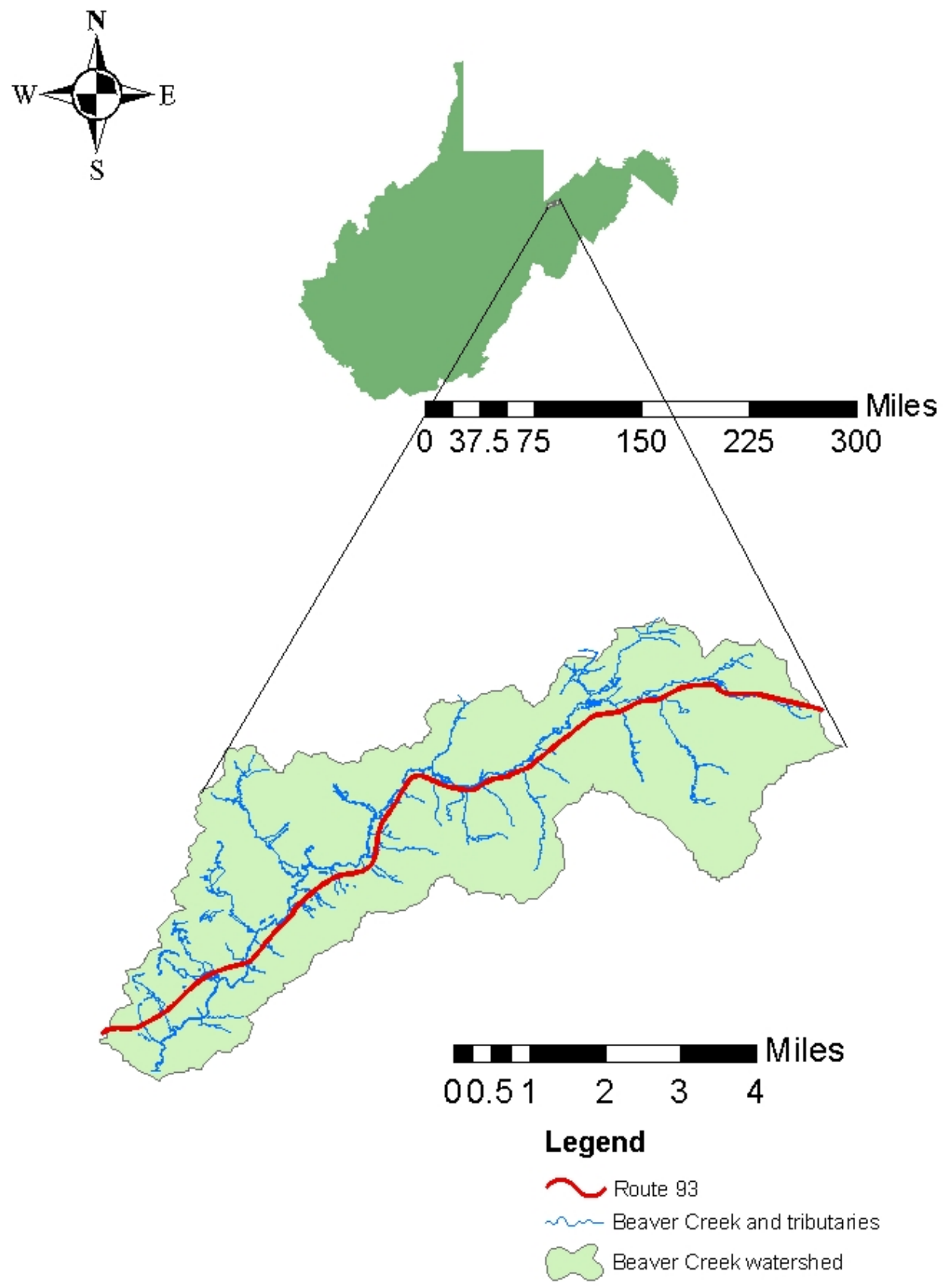

Figure 3.7 - Location Of Beaver Creek Watershed In West Virginia. 


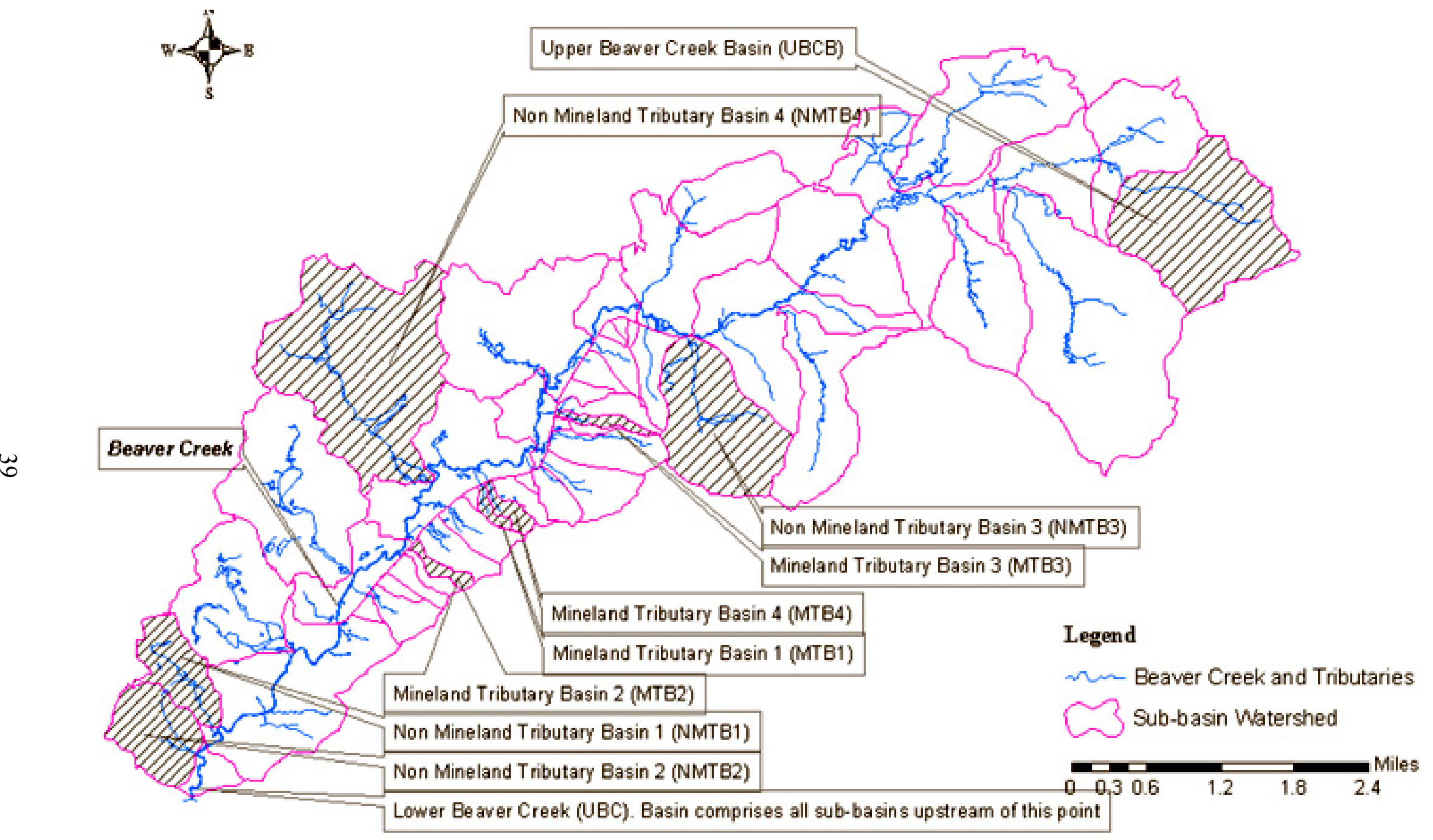

Figure 3.8 - Sub-Basin Watershed Boundaries Of Beaver Creek Watershed. Sub-basins studied are cross hatched. 


\subsubsection{Description Of Sub-basins.}

The delineation of watersheds for the study reaches resulted in sub-basins having drainage areas ranging from $0.04 \mathrm{mi}^{2}$ to $21.18 \mathrm{mi}^{2}$. The sub-basins of the mineland tributaries were small compared to sub-basins of the non-mineland tributaries. Bankfull observations were made on the tributaries close to Beaver Creek such that they could be used as discharge points in the HEC-HMS analysis. The details of the reaches and basins are presented in Table 3.7 in the order of increasing drainage areas. Longitudinal and cross-sectional surveys were done on each study reach in accordance with the procedures listed in USDA SCS (1985). Locations of the study reaches were either just upstream or just downstream of the culverts under Route 93. The study reaches were separated enough from the culvert to avoid the backwater effects from the culvert.

Photographs and perspective views (obtained from HEC-RAS) of each study reach are shown in Figures 3.9 - 3.28. The meander of the reaches is not accurately shown in the perspective views, and the ratio of vertical to horizontal lengths has been varied to give a better view of the reach. The water stage elevation shown in blue, in the perspective view, corresponds to the bankfull stage. Where a photograph of the reach is not available, a cross-section plot of an identified bankfull location is presented.

Mineland streams MT1, MT2, MT3, and MT4 had small drainage areas and originated from mineland spoils. A lot of mineral precipitation (iron) was visible in MT1 and MT3, and they formed a series of step-pools along their length. MT2 and MT4 showed features of lateral widening along their length and a lot of isolated sediment deposits, especially at pool sections. They had little vegetation along their banks.

Non-mineland streams NMT1, NMT2, NMT3, and NMT4 had drainage areas larger than the mineland streams. They had well defined bankfull features. The study reaches did not have mineland spoil near them. NMT2 flowed very close to the town of Davis and had a small tributary (about $10 \%$ of its flow) joining before the study reach. The study reach for NMT4 was very sinuous and was on a swampy area.

Stream UBC was the headwaters of Beaver Creek. The LBC reach was on the Beaver Creek itself before joining Blackwater River. 
Table 3.7 - Hydrologic Description Of The Study Basins And Tributaries.

\begin{tabular}{|c|c|c|c|c|c|c|}
\hline \multirow{2}{*}{$\begin{array}{l}\text { Basin } \\
\text { Identity }\end{array}$} & \multirow{2}{*}{$\begin{array}{l}\text { Drainage } \\
\text { Area } \\
\left(\mathrm{mi}^{2}\right)\end{array}$} & \multirow{2}{*}{$\begin{array}{l}\text { Reach } \\
\text { Identity }\end{array}$} & \multirow{2}{*}{$\begin{array}{l}\text { Hydrologic } \\
\text { Soil Group }^{\text {a }}\end{array}$} & \multirow[t]{2}{*}{ Land Cover Types $^{b}$} & \multicolumn{2}{|c|}{ Channel Length } \\
\hline & & & & & $\begin{array}{l}\text { Surveyed } \\
\text { Reach (ft) }\end{array}$ & $\begin{array}{c}\text { Total } \\
\text { (ft) }\end{array}$ \\
\hline MTB1 & 0.04 & MT1 & C and D & UFO1, UFO4, UHU \& USS1 & 70 & 3004 \\
\hline MTB2 & 0.059 & MT2 & $\mathrm{C}$ and $\mathrm{D}$ & UAA, UFO1, UFO4 \& UHU & 88 & 3961 \\
\hline MTB3 & 0.059 & MT3 & $\mathrm{C}$ and $\mathrm{D}$ & PEM1, UFO1, UFO4, UHU \& UUV & 91 & 3681 \\
\hline MTB4 & 0.065 & MT4 & $\mathrm{C}$ and $\mathrm{D}$ & UFO1, UFO4 \& UHU & 94 & 3845 \\
\hline NMTB1 & 0.327 & NMT1 & $\mathrm{C}$ and $\mathrm{D}$ & $\begin{array}{l}\text { PEM1, PFO1, PML1, POW, PSS1, Water, UAA, UFO1, UFO4, } \\
\text { UHU, USS1 \& USS8 }\end{array}$ & 96 & 7574 \\
\hline NMTB2 & 0.426 & NMT2 & C and D & $\begin{array}{l}\text { PEM, PEM1, PFO1, PML1, PSS1, Water, UAA, UFO1, UFO4, } \\
\text { UFO8, UHU \& USS1 }\end{array}$ & 89 & 8603 \\
\hline NMTB3 & 0.918 & NMT3 & C and D & PEM1, PFO1, PSS1, Water, UFO1, UFO4, UFO8, UHU \& UUV & 96 & 9768 \\
\hline UBCB & 1.425 & UBC & $\mathrm{C}$ and $\mathrm{D}$ & $\begin{array}{l}\text { PEM, PML1, Water, UFO1, UFO4, UFO8, UHU, USS1, USS4, } \\
\text { USS8 \& UUV }\end{array}$ & 104 & 12902 \\
\hline NMTB4 & 1.971 & NMT4 & $\mathrm{C}$ and $\mathrm{D}$ & $\begin{array}{l}\text { PEM1, PFO1, PFO4, PFO8, PML1, PSS1, PSS5, Water, UAA, } \\
\text { UFO1, UFO4, UFO8, UHU, USS1 \& UUV }\end{array}$ & 70 & 13544 \\
\hline LBCB & 22.176 & LBC & $\mathrm{B}, \mathrm{C}$ and $\mathrm{D}$ & $\begin{array}{l}\text { PEM1, PF01, PFO1, PFO4, PFO5, PFO8, PML1, POW, } \\
\text { PSS1, PSS4, PSS5, Water, UAA, UFO1, UFO4, UFO8, UHU, } \\
\text { USS1, USS4, USS8 \& UUV, Road }\end{array}$ & 140 & 99619 \\
\hline
\end{tabular}

\footnotetext{
a - Please refer to Table 3.1, Table 3.2 and Figure 3.3 for description of Soil Groups in Beaver Creek.

b - Please refer to Table 3.3 and Figure 3.4 for description of Land use / land cover in Beaver Creek.
} 


\subsubsection{Reach Pictorials}

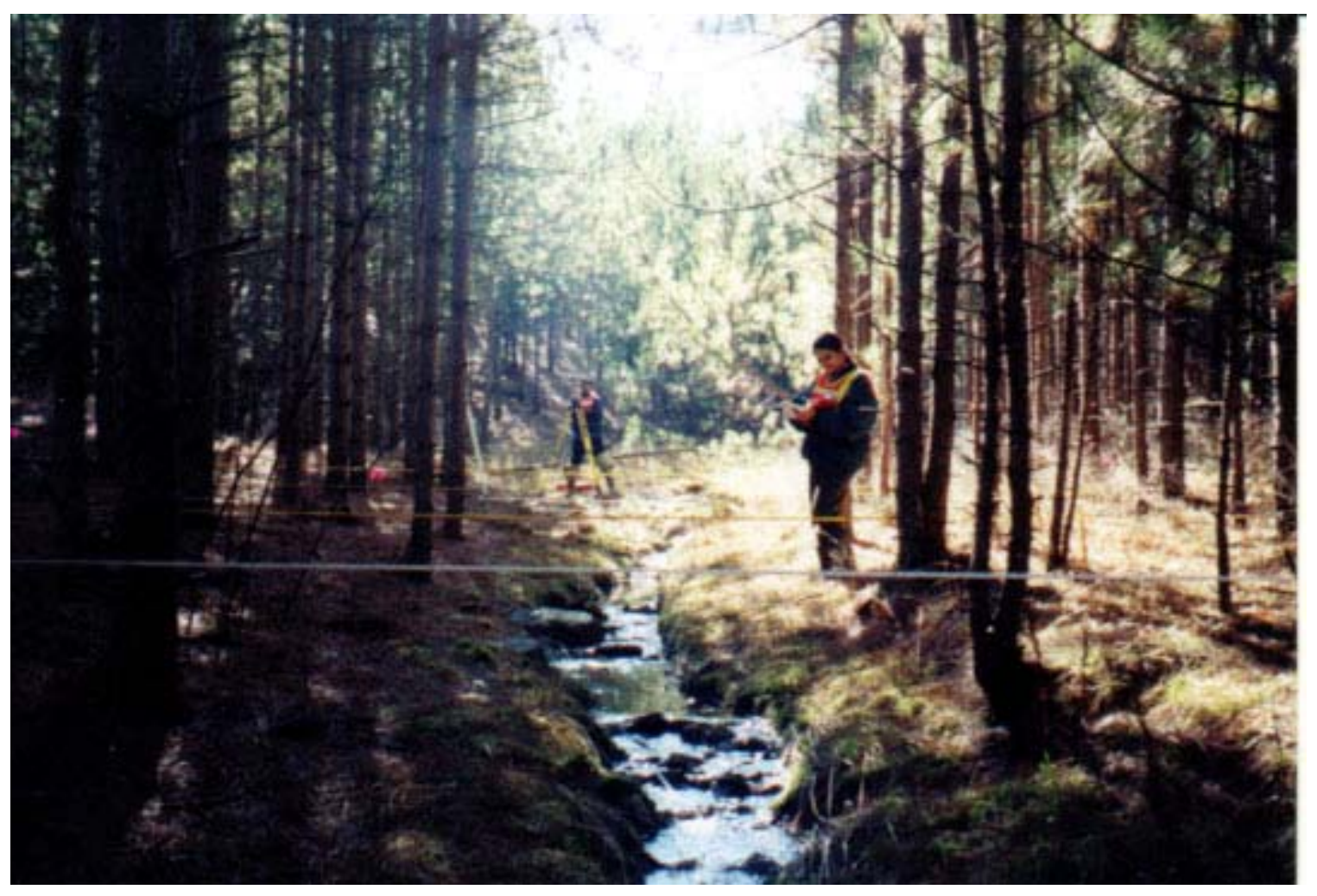

Figure 3.9- Upstream View Of Study Reach For MT1.

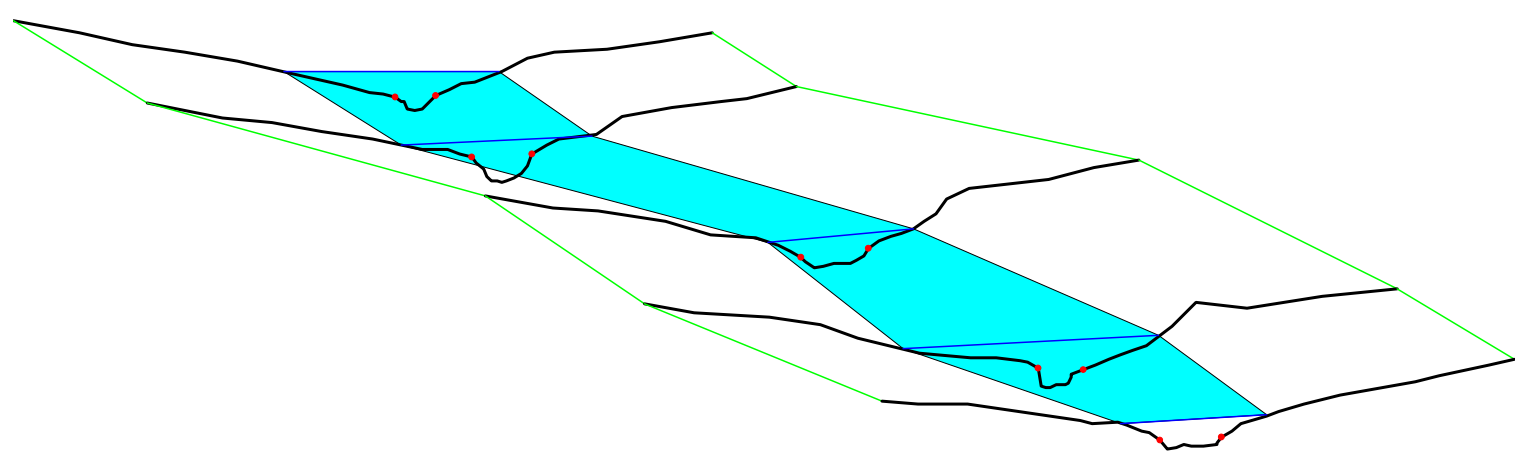

Figure 3.10 - Perspective View Of Study Reach For MT1. 


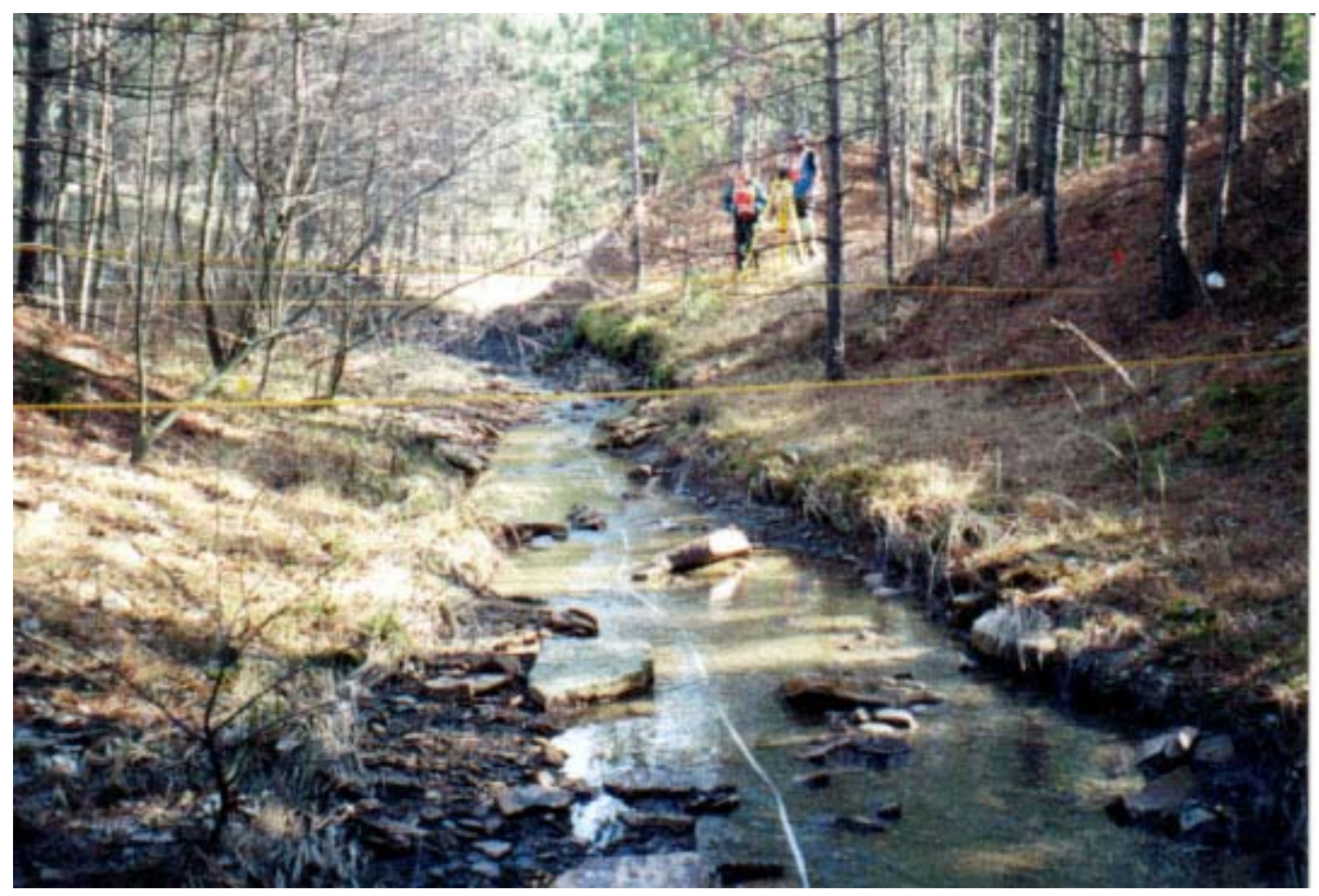

Figure 3.11 - Upstream View Of Study Reach For MT2.

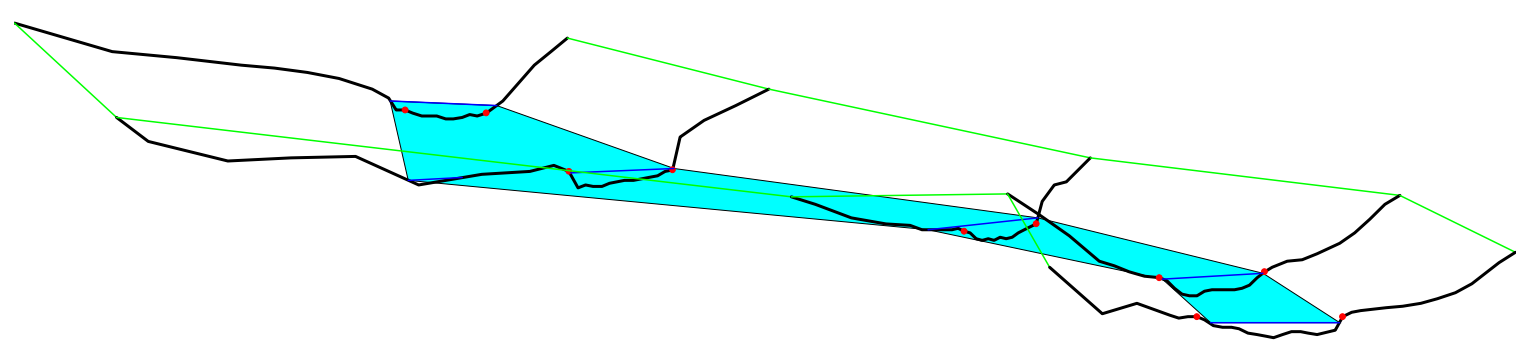

Figure 3.12 - Perspective View Of Study Reach For MT2. 


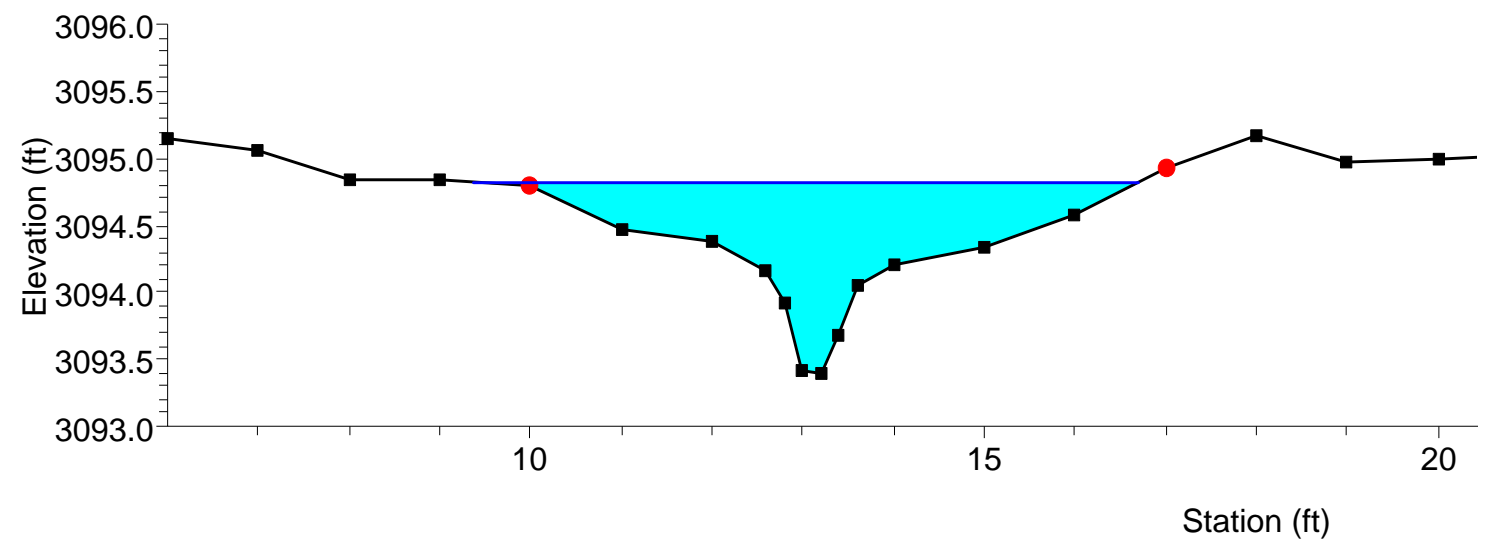

Figure 3.13 - Typical Cross-Section Of MT3.

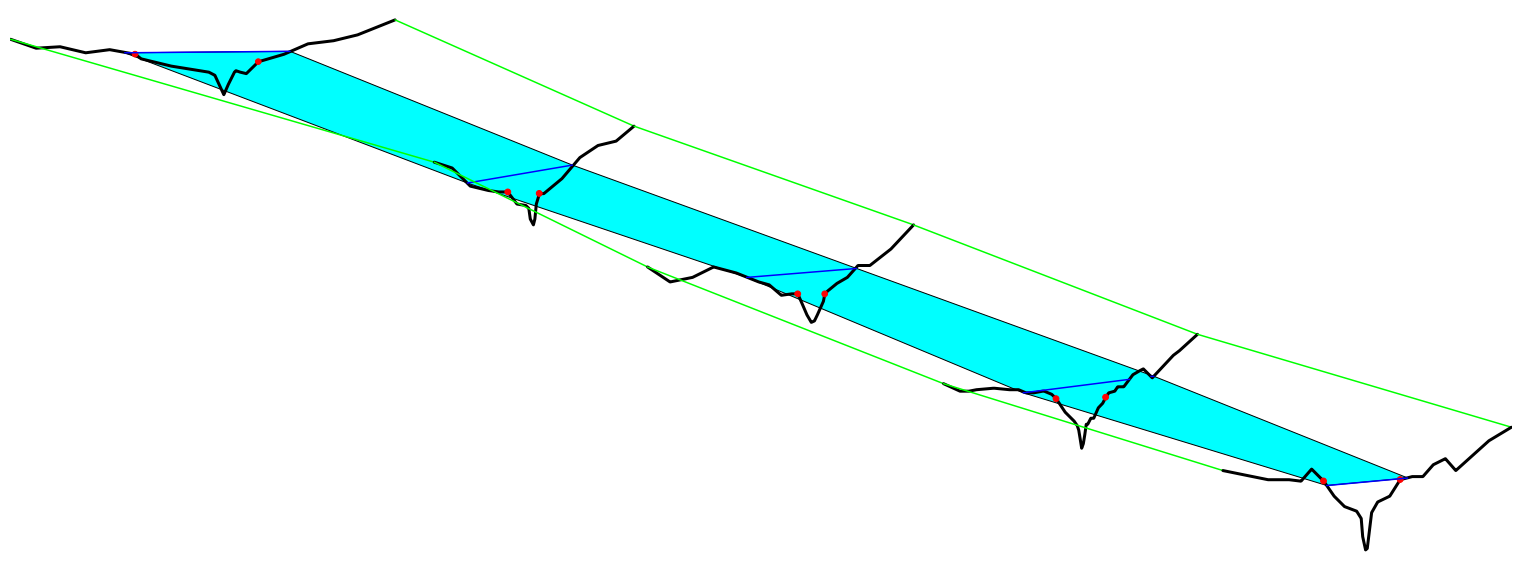

Figure 3.14 - Perspective View Of Study Reach For MT3. 


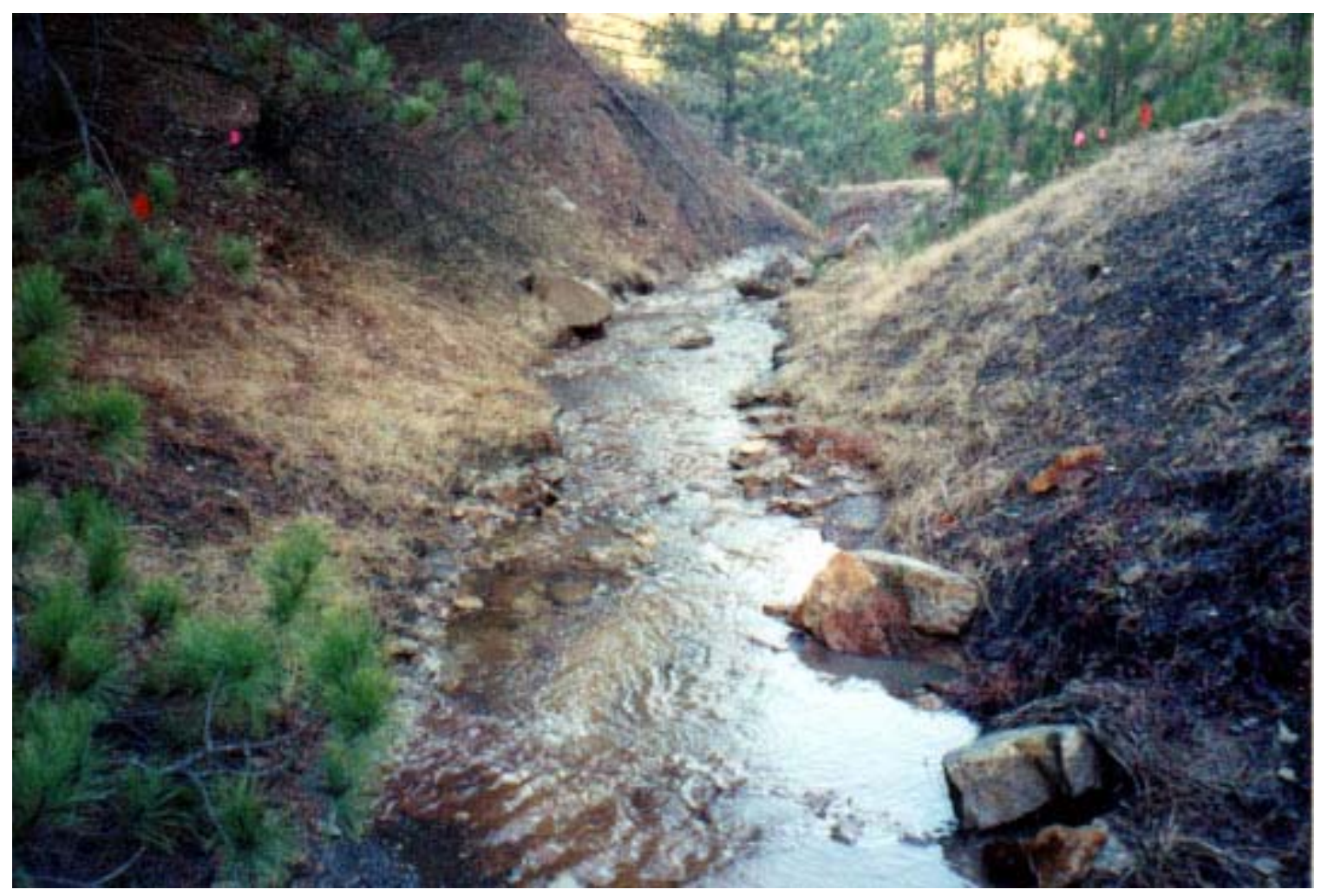

Figure 3.15 - Downstream View Of Study Reach For MT4.

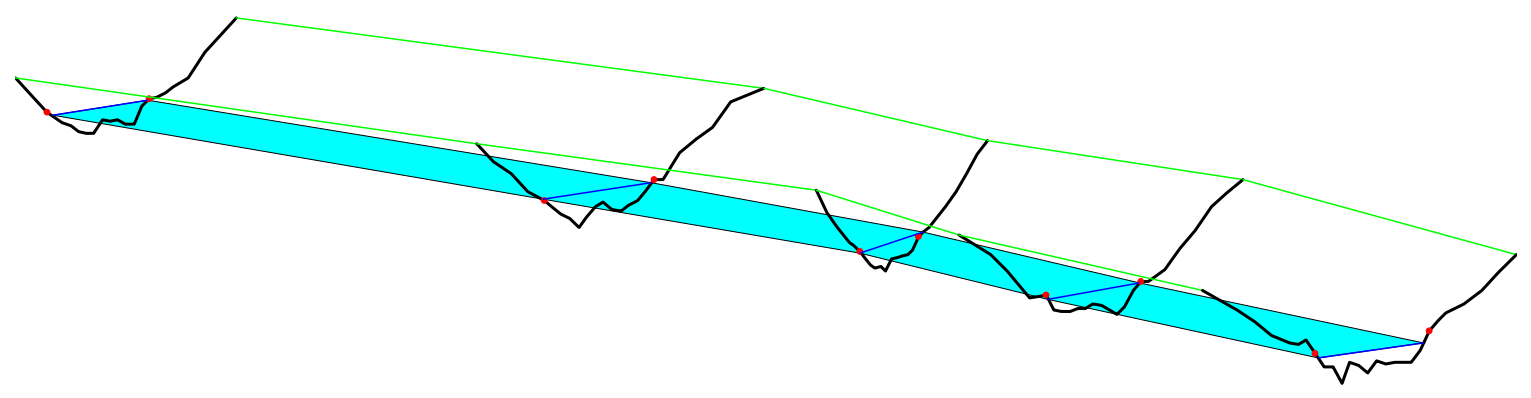

Figure 3.16 - Perspective View Of Study Reach For MT4. 


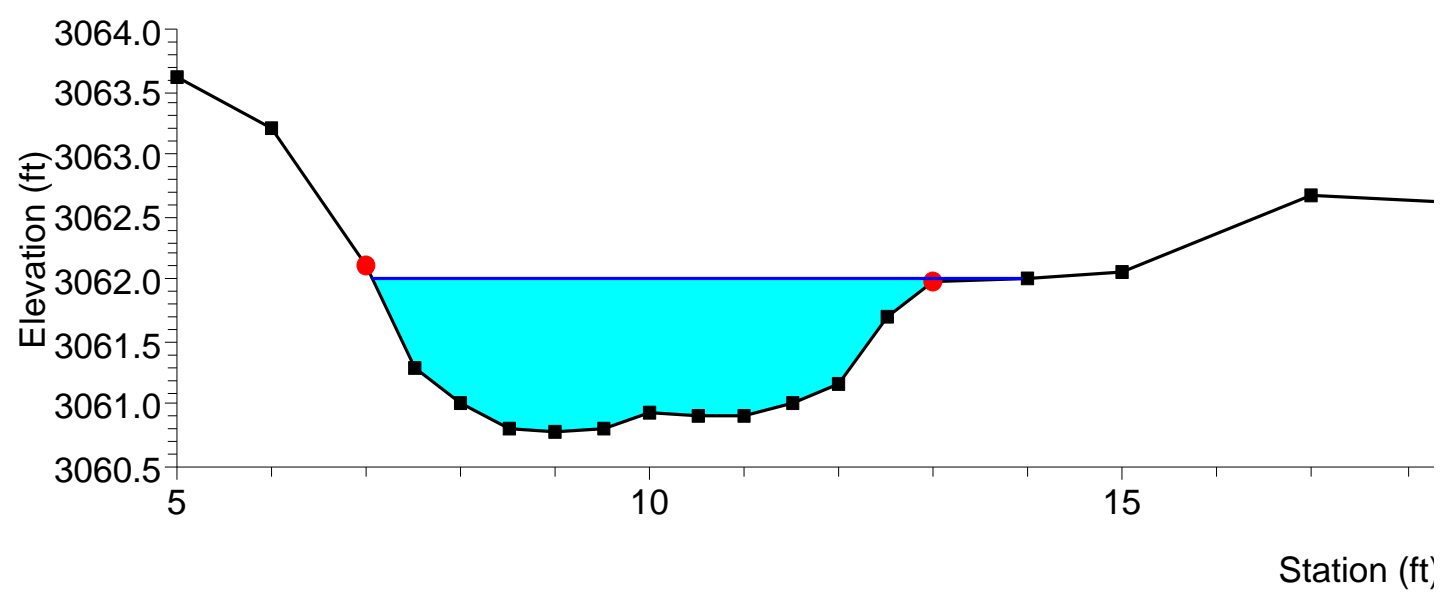

Figure 3.17 - Typical Cross-Section Of NMT1.



Figure 3.18 - Perspective View Of Study Reach For NMT1. 


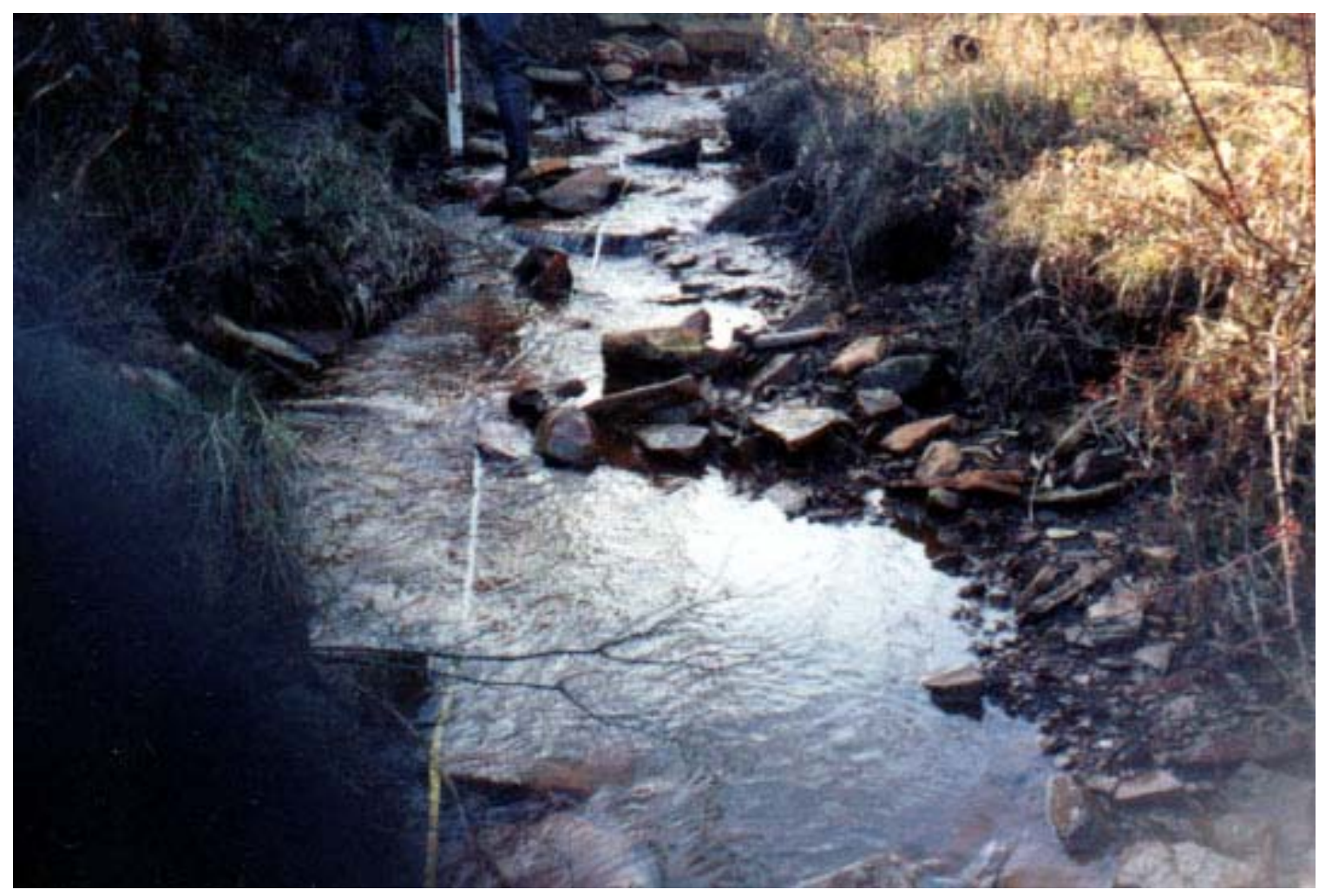

Figure 3.19 - Upstream View Of Study Reach For NMT2.

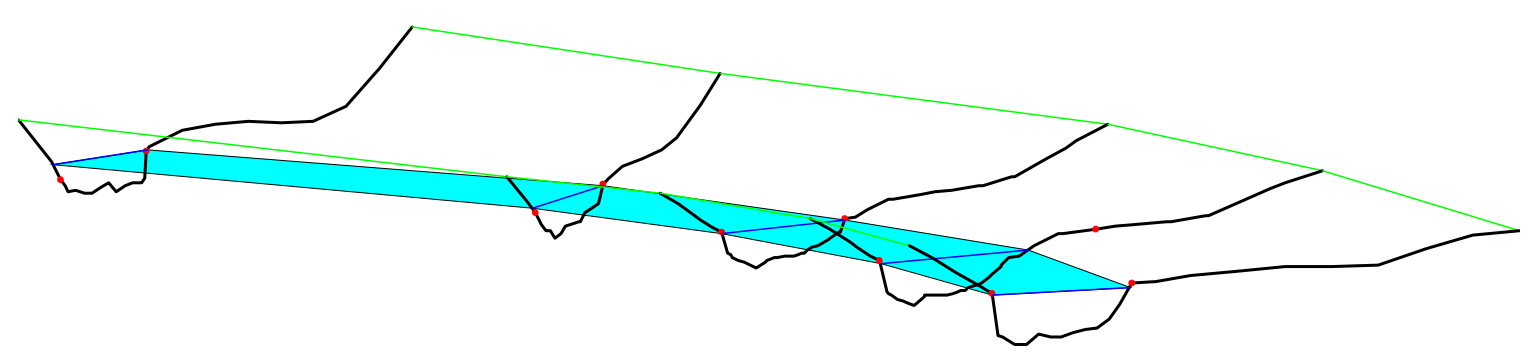

Figure 3.20 - Perspective View Of Study Reach For NMT2. 


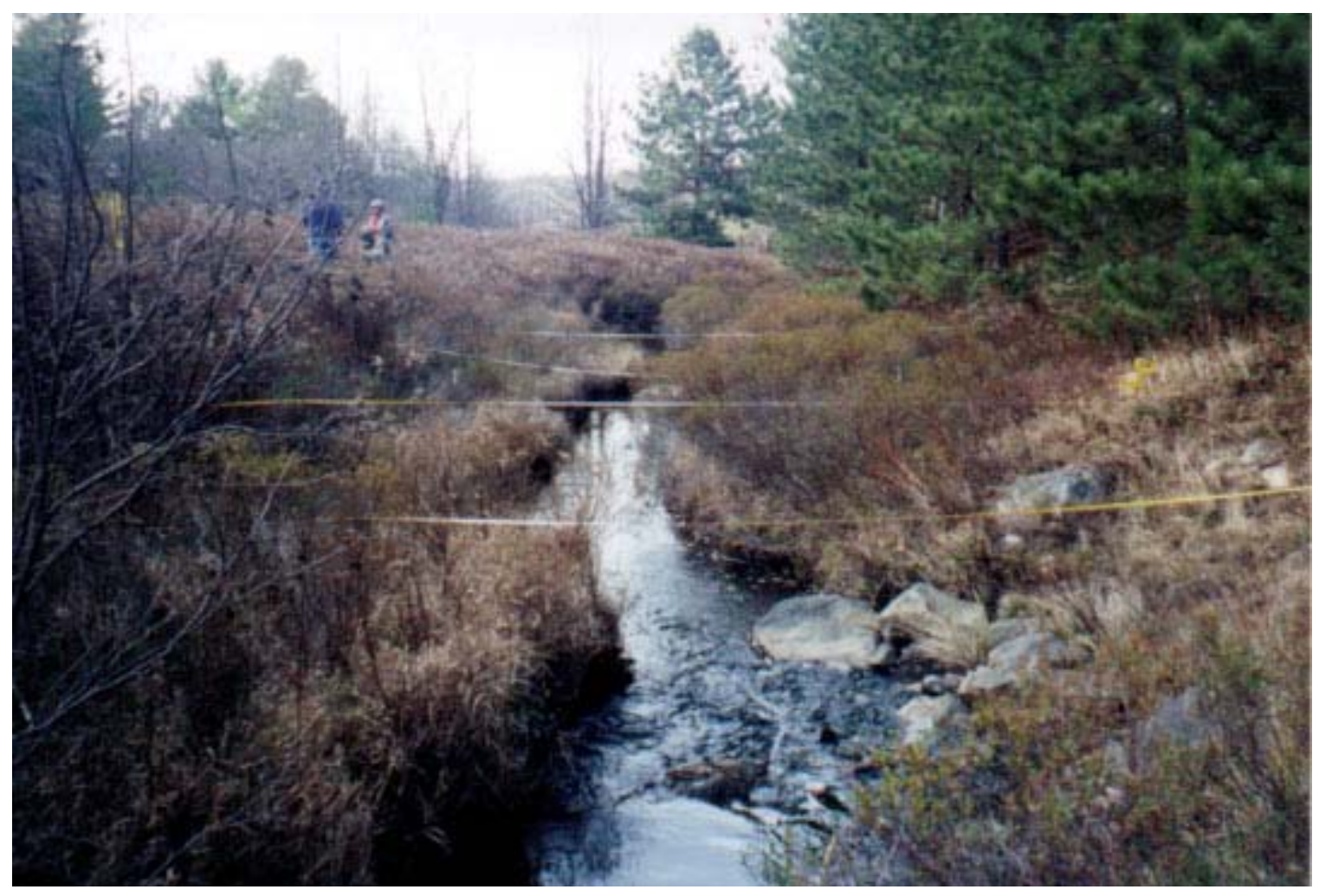

Figure 3.21 - Downstream View Of Study Reach For NMT3.

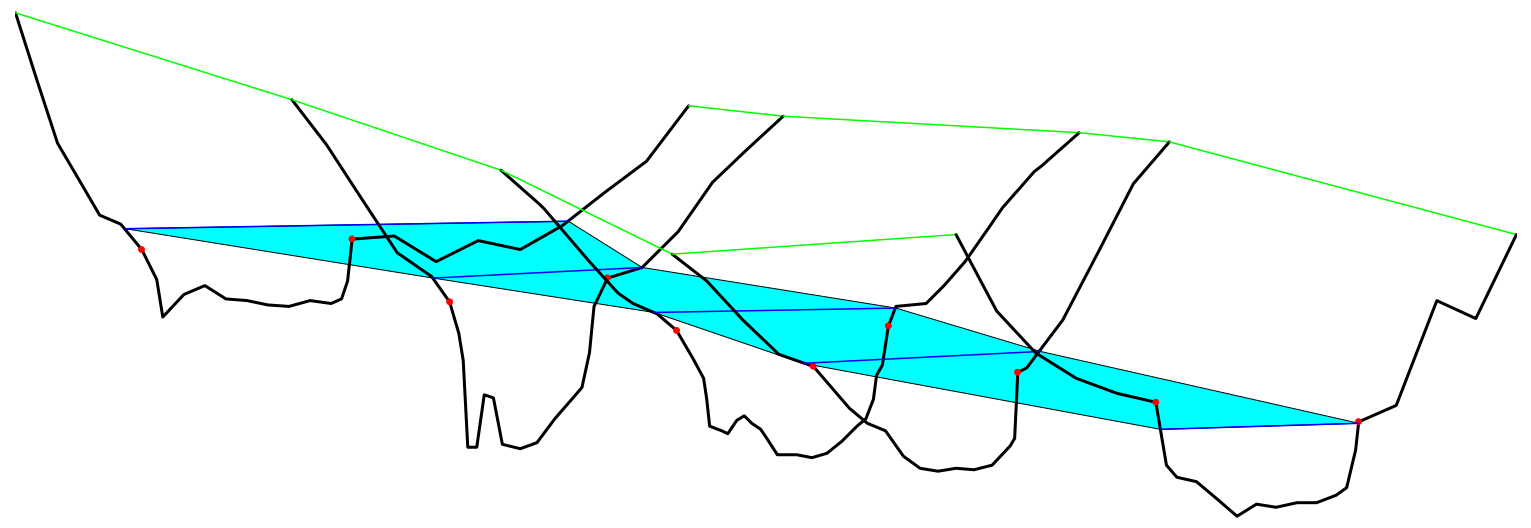

Figure 3.22 - Perspective View Of Study Reach For NMT3. 


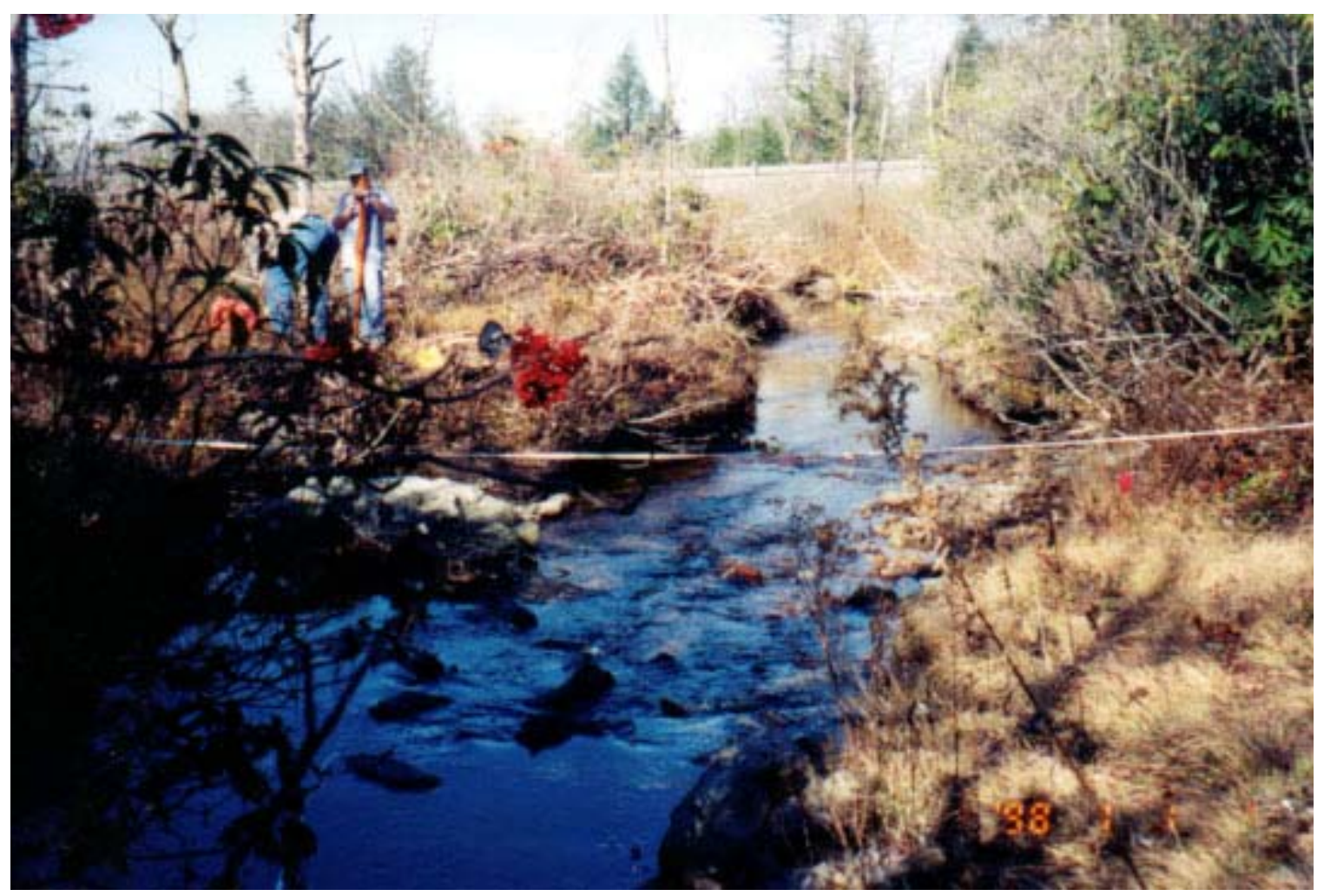

Figure 3.23 - Downstream View Of Study Reach For UBC.

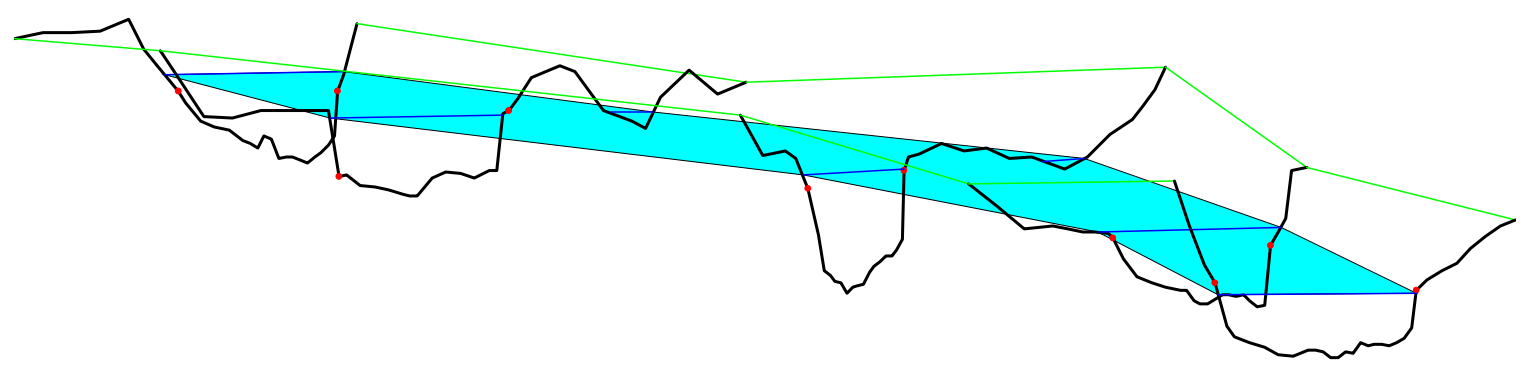

Figure 3.24 - Perspective View Of Study Reach For UBC. 


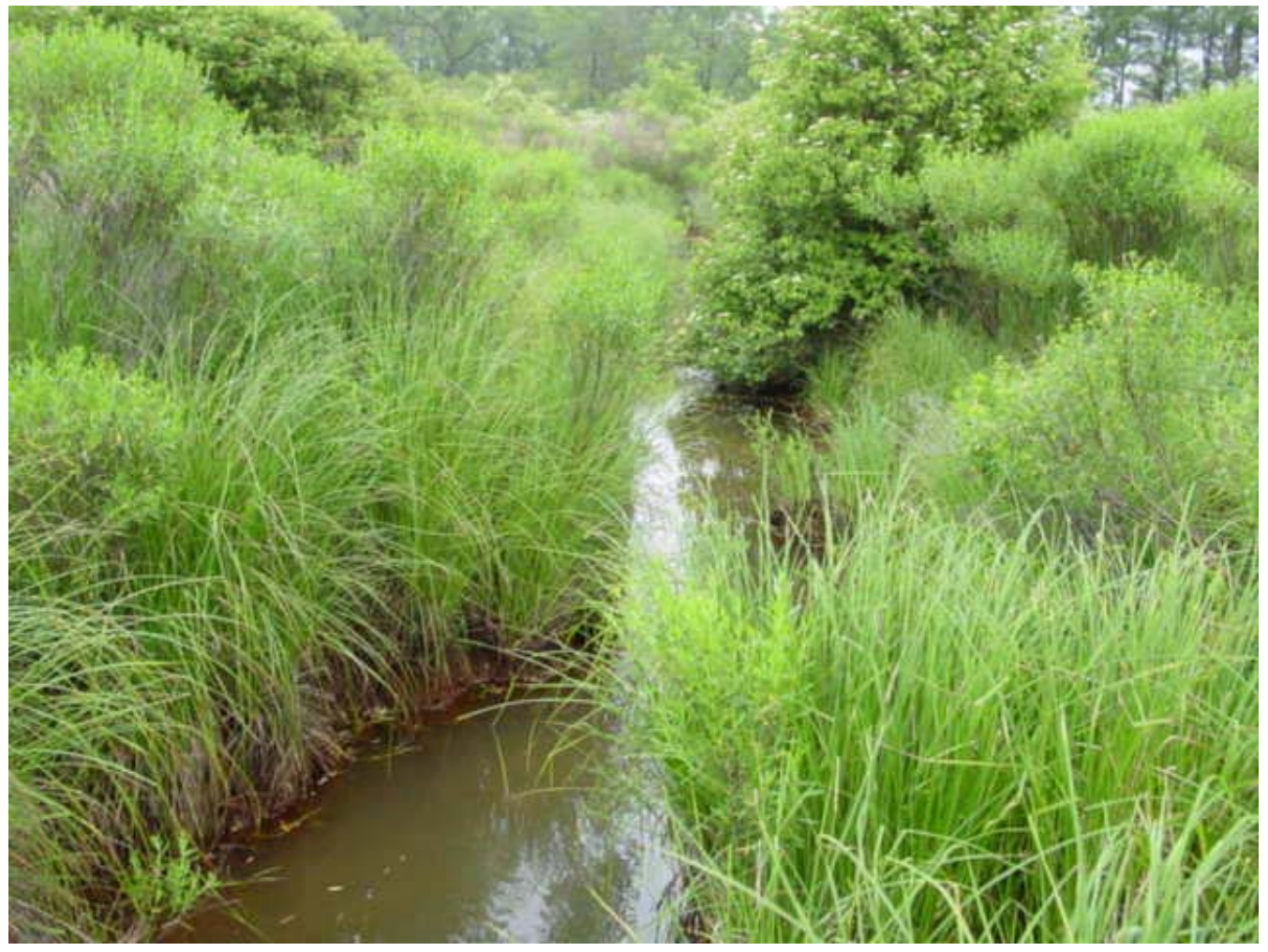

Figure 3.25 - Downstream View Of Study Reach For NMT4.

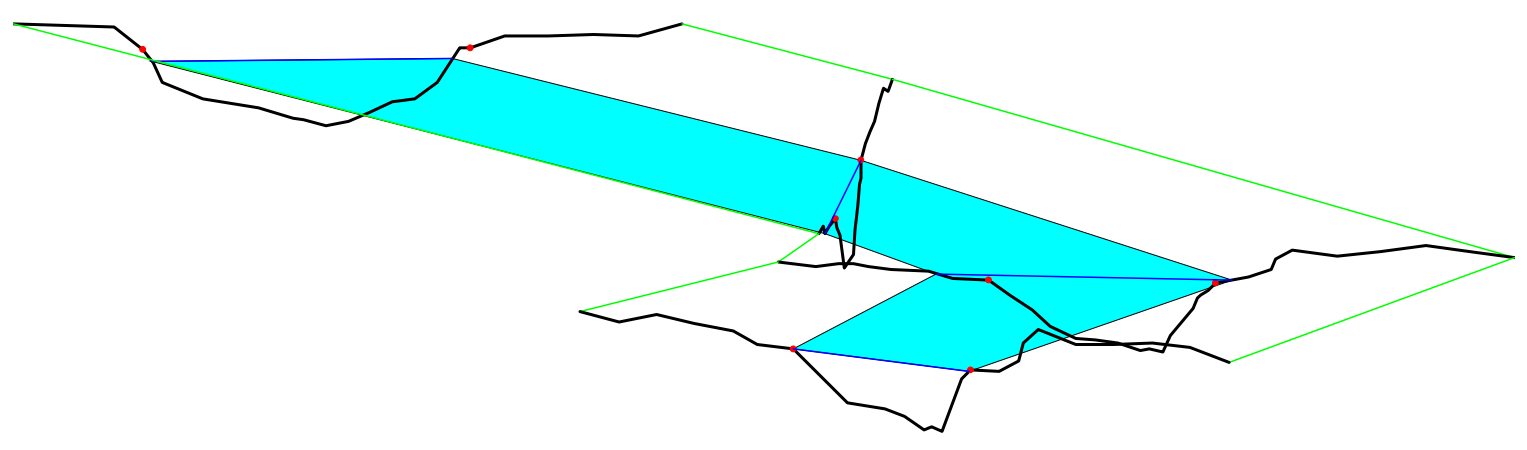

Figure 3.26 - Perspective View Of Study Reach For NMT4. 


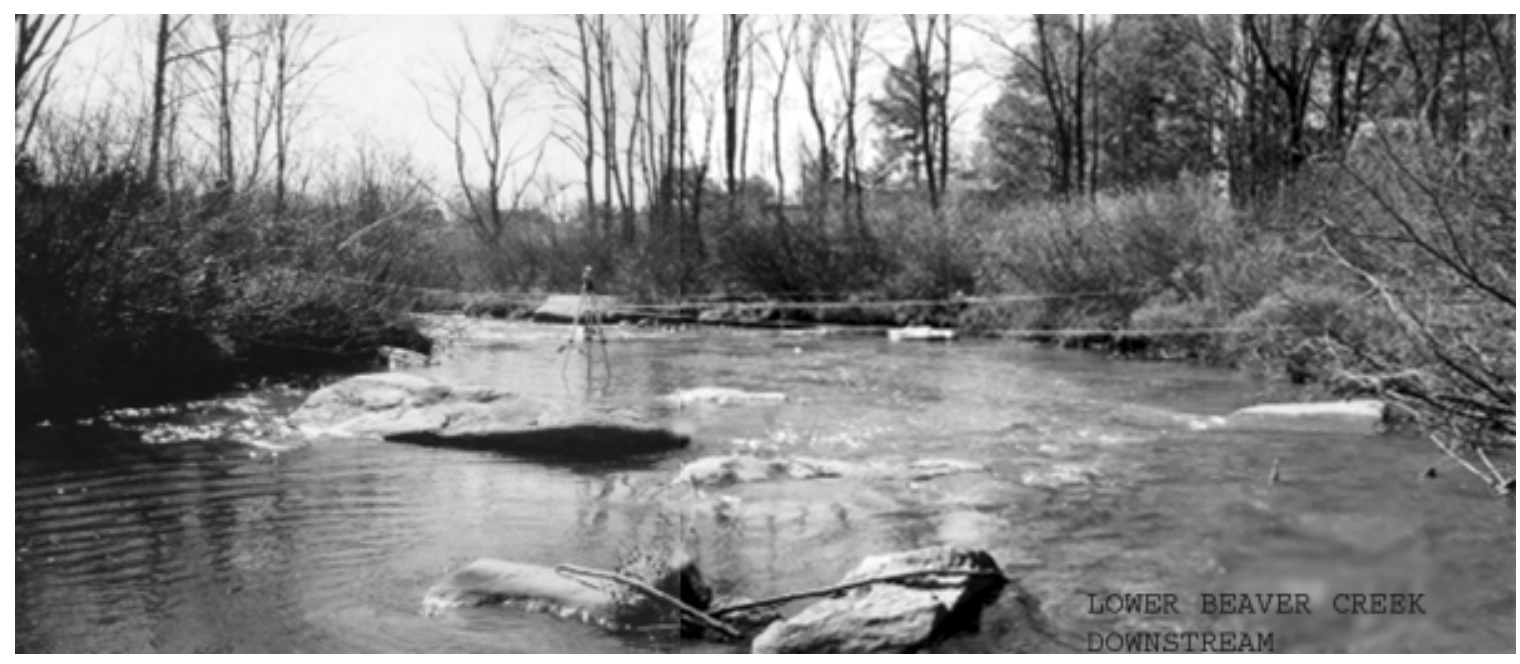

Figure 3.27 - Downstream View Of Study Reach For LBC.

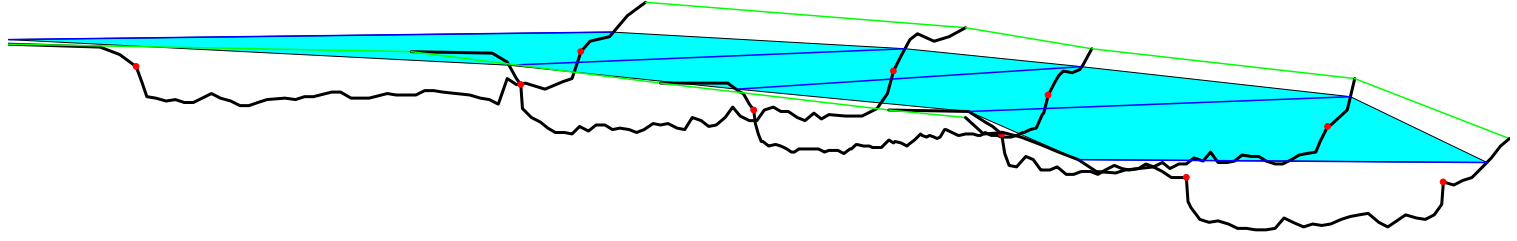

Figure 3.28 - Perspective View Of Study Reach For LBC. 


\section{CHAPTER 4 COMPUTATION AND RESULTS}

\subsection{HEC-RAS Analysis}

Once the field data had been collected, the next step was to use these data in the HEC-RAS program to predict the bankfull discharge. Since none of the surveyed streams had been gaged prior to this study, rating curves were not available to predict the bankfull discharge. The hydraulic model HEC-RAS was selected for the analysis as it is the most extensively used program for such studies. HEC-RAS was developed by the Hydrologic Engineering Center, which is a division of the Institute for Water Resources, U.S. Army Corps of Engineers (HEC, 2002).

Hydraulic modeling with HEC-RAS for this study involves the following steps:

- Entering Geometric Data;

- Entering Flow Data;

- Performing Steady flow analysis; and

- Reviewing Subcritical flow output.

Geometric data in the HEC-RAS program can be entered via selecting the Geometric Data from the edit menu. The river reach schematic is drawn by selecting the River Reach button. The cross-section editor also requires the Manning's n value as input for the overbanks as well as the channel. Then the cross-section data are entered by choosing the cross-section editor. A sample cross-section plot is shown in Figure 4.1.

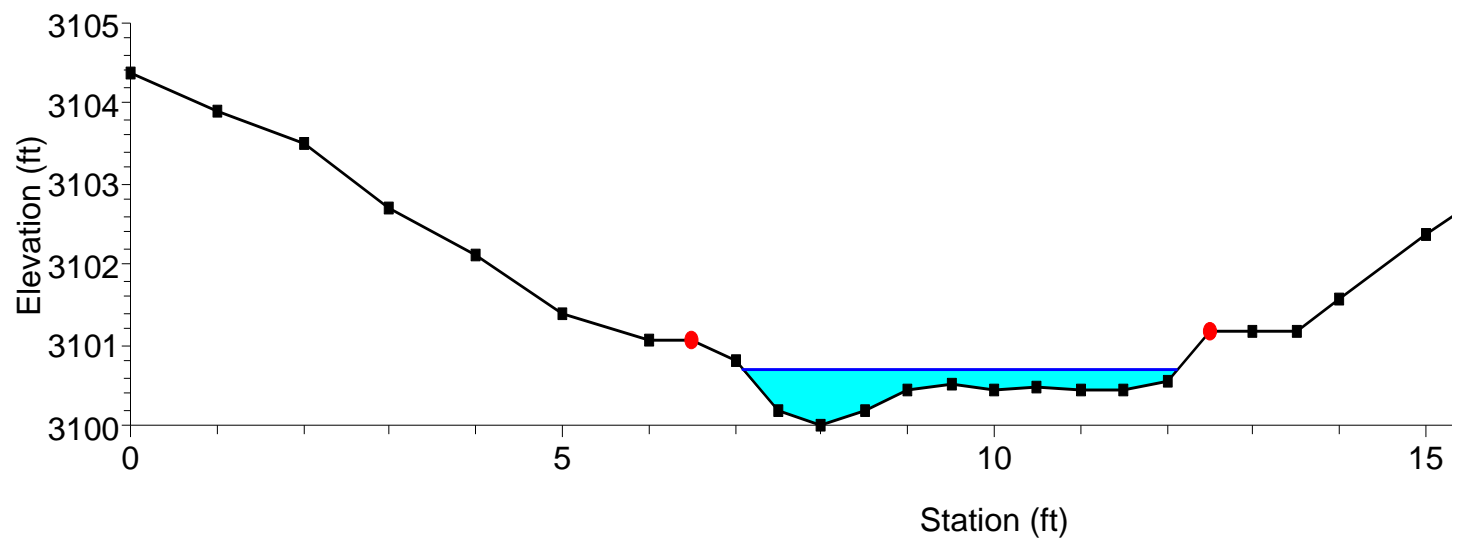

Figure 4.1 - Typical Bankfull Cross-Section For MT4. 
Once the channel geometry had been entered, the next step was to generate a flow that would give the bankfull depth for the reach. This was done by trial and error. Estimates for the bankfull peak flow were provided. Steady flow analysis was performed with subcritical flow regime. The output cross-section and results were viewed to match the water surface elevation with the elevation of bankfull found during the field survey. A sample cross-section plot can be seen in Figure 4.2. Similar analyses were done for all the bankfull locations of all reaches. Table A1 - A10 in Appendix A shows the hydraulic characteristics of the study reaches at bankfull stage at each surveyed cross-section.

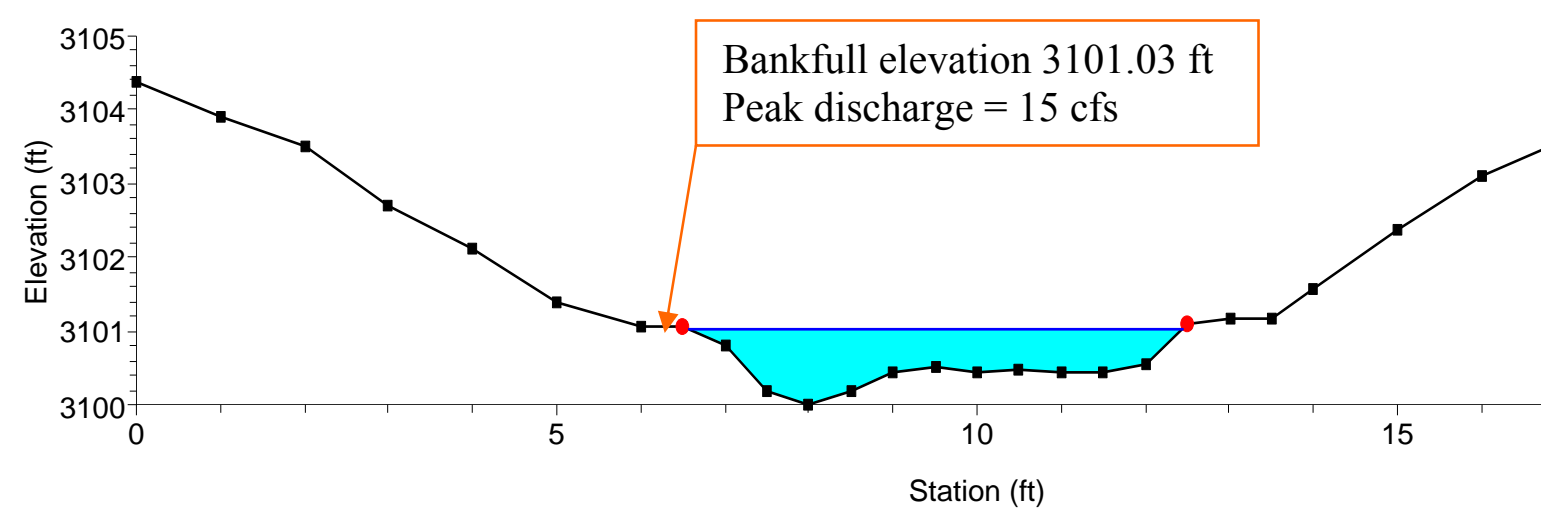

Figure 4.2 - Typical Cross-section Of Reach MT4 At Bankfull Discharge. 


\subsection{Power Function Regression Equations}

Bankfull parameters were calculated from the results. Of major interest in this analysis are the peak flow, top width, cross-sectional area, and depth. The values of all these parameters at bankfull stages are tabulated in Table 4.1. The hydraulic geometry relationships for bankfull discharge, cross-sectional area, width and mean depth as functions of watershed area are shown in Figures 4.3 to 4.6. The power function regression equations and corresponding coefficients of determination (obtained from MSExcel Data Analysis Tools) are:

$$
\begin{aligned}
& Q_{b k f}=65.476 A^{0.6057} ;\left(\mathrm{R}^{2}=0.96\right) \\
& A_{b k f}=15.586 A_{d}^{0.578} ;\left(\mathrm{R}^{2}=0.95\right) \\
& W_{b k f}=13.905 A_{d}^{0.2946} ;\left(\mathrm{R}^{2}=0.80\right) \\
& D_{b k f}=1.1209 A_{d}^{0.2836} ;\left(\mathrm{R}^{2}=0.95\right)
\end{aligned}
$$

where,

$Q_{b k f}$ - Bankfull discharge (cfs);

$A_{b k f}$ - Bankfull cross-sectional area $\left(\mathrm{ft}^{2}\right)$;

$W_{b k f}$ - Bankfull width (ft);

$D_{b k f}$ - Bankfull mean depth or hydraulic depth (ft); and

$A_{d}$ - Watershed drainage area $\left(\mathrm{mi}^{2}\right)$

The high coefficients of determination indicate good agreement between the measured data and the best-fit relationships. These relationships are only applicable to the streams in Beaver Creek watershed having drainage areas from 0.04 to 22.18 square miles. 
Table 4.1 - Geometric Parameters Of Reaches At Bankfull Depth.

\begin{tabular}{|c|c|c|c|c|c|c|c|}
\hline \multirow{2}{*}{$\begin{array}{c}\text { Sub-basin } \\
\text { identity }\end{array}$} & \multirow{2}{*}{$\begin{array}{c}\text { Reach } \\
\text { identity }\end{array}$} & \multirow{2}{*}{$\begin{array}{l}\text { Area } \\
\left(\mathrm{mi}^{2}\right)\end{array}$} & \multicolumn{5}{|c|}{ Bankfull dimensions } \\
\hline & & & Flow (cfs) & Depth (ft) & Width (ft) & Area $\left(\mathbf{f t}^{2}\right)$ & Velocity (ft/s) \\
\hline MTB1 & MT1 & 0.040 & 13 & 0.46 & 7.61 & 3.5 & 4.46 \\
\hline MTB2 & MT2 & 0.059 & 12 & 0.43 & 7.51 & 3.2 & 3.75 \\
\hline MTB3 & MT3 & 0.059 & 13 & 0.45 & 7.34 & 3.3 & 3.95 \\
\hline MTB4 & MT4 & 0.065 & 15 & 0.58 & 5.82 & 3.4 & 4.41 \\
\hline NMTB1 & NMT1 & 0.327 & 22 & 0.78 & 6.88 & 5.38 & 4.1 \\
\hline NMTB2 & NMT2 & 0.426 & 28 & 1.02 & 7.22 & 7.39 & 3.79 \\
\hline NMTB3 & NMT3 & 0.918 & 51 & 1.34 & 12.04 & 16.08 & 3.22 \\
\hline UBCB & $\mathrm{UBC}$ & 1.425 & 80 & 1.03 & 12.98 & 13.37 & 6.04 \\
\hline NMTB4 & NMT4 & 1.971 & 95 & 1.51 & 15.62 & 23.58 & 4.08 \\
\hline LBCB & $\mathrm{LBC}$ & 22.176 & 620 & 2.46 & 55.08 & 135.29 & 4.66 \\
\hline
\end{tabular}




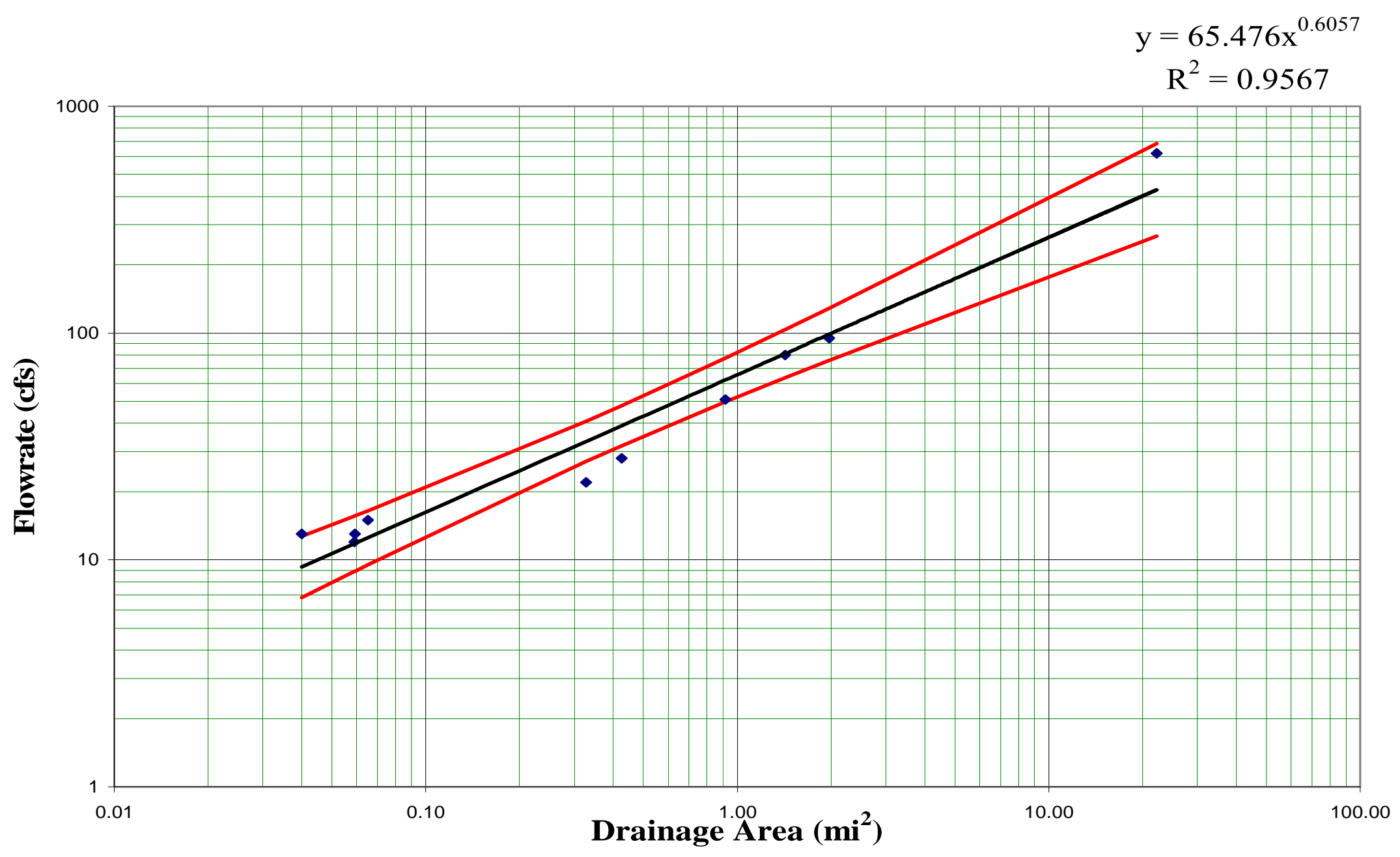

Figure 4.3 - Bankfull Discharge As A Function Of Drainage Area With 95\% Confidence Band. 


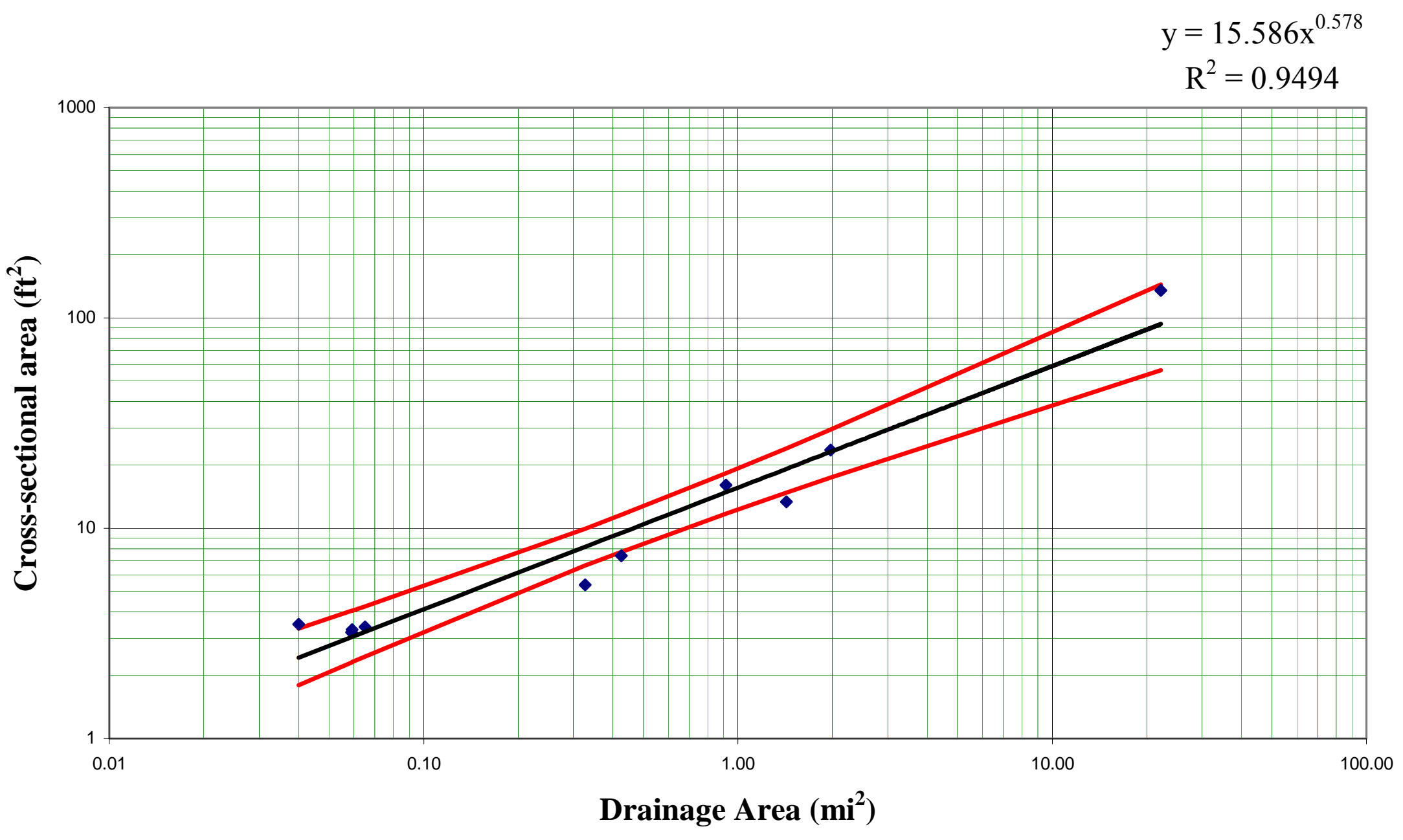

Figure 4.4 - Bankfull Cross-Sectional Flow Area As A Function Of Drainage Area With 95\% Confidence Band. 


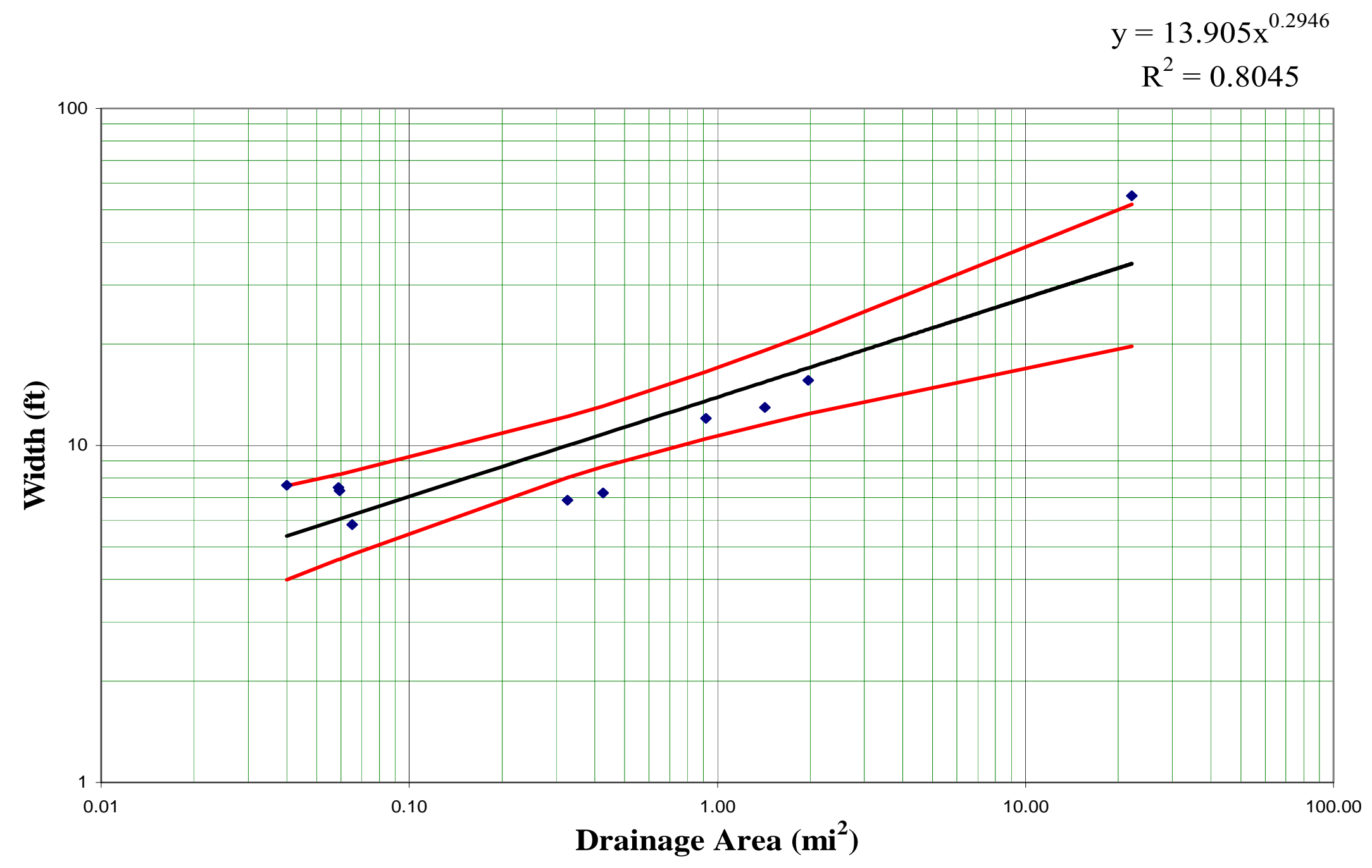

Figure 4.5 - Bankfull Width As A Function Of Drainage Area With 95\% Confidence Band. 


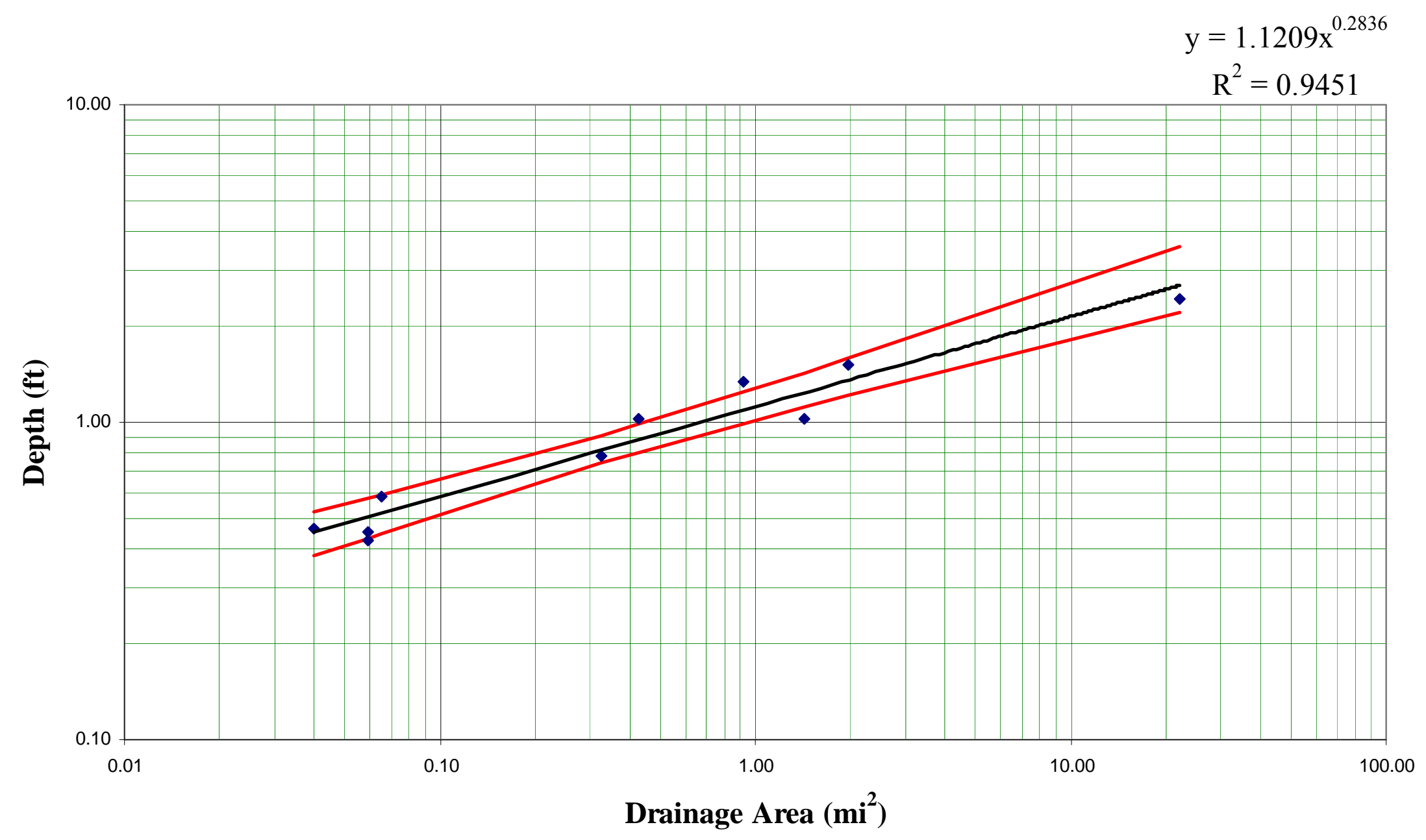

Figure 4.6 - Bankfull Depth As A Function Of Drainage Area With 95\% Confidence Band. 


\subsection{Confidence Interval Band For The Regional Curves}

The hydraulic geometry relationships for bankfull discharge, cross-sectional area, width, and mean depth have been determined using numerical models and site investigations. The power function regression equations and corresponding coefficients of determination show good agreement between the measured data and best-fit relationships. In order estimate the uncertainty of these relationships; confidence limits were created for each relationship. The best-fit regression equations and the upper and lower 95\% confidence limits determined using MS Excel Data Analysis Tools are shown for each relationship (Figures 4.3 - 4.6). The black line indicates the best-fit correlation and the red lines indicate the upper and lower confidence lines.

The $95 \%$ confidence band indicates that the mean of the function has a probability of $95 \%$ to lie within the confidence band. However, the wide range of the values included within the $95 \%$ confidence limits indicates the need for caution when using these relationships. For example, the bankfull flowrate for a 1 square mile watershed ranges from approximately 51 to $81 \mathrm{cfs}$ with a predicted value of $65.5 \mathrm{cfs}$. This range of variability increases as the watershed area increases. The $95 \%$ confidence interval band is valid only for the range of values of drainage area from 0.04 to 22.18 square miles for which data have been observed. 


\subsection{Determination Of Bankfull Return Period}

Having developed the bankfull geometric parameters as functions of drainage area, the next step was to estimate the return period that would correspond to the bankfull discharge. The bankfull recurrence interval was obtained by estimating the peak discharge that was closest to the bankfull discharge given by HEC-RAS. Regional regression equations were primarily chosen to estimate the peak discharges. Due to the limitations of the drainage areas to be used in the regional regression equations, the recurrence interval for some study basins was found by the HEC-HMS model.

\subsubsection{Regional Regression Analysis}

The peak discharge was estimated using the regional regression equations developed by Wiley et al. (2002) with recurrence intervals between 1.1 and 3.0 years. Only study basins that had drainage areas within the limits of drainage area for the Eastern Region of West Virginia ( 0.22 - 1486 square miles) were selected. Due to this limitation, the 4 mineland tributaries could not be included in the analysis since their drainage areas were too small. The peak discharges for the remaining sub-basins using the regional regression equations for the Eastern Region of West Virginia are shown in

\section{Table 4.2.}

From the regional regression analysis and the bankfull peak flow it can be seen that the return interval for these streams falls within the range 1.3 to 1.9 years. Except for lower Beaver Creek, where the drainage area is very much higher than the rest of the tributaries and the headwaters, the return period of the rest of the watersheds varies from 1.6 to 1.9 years and has an average value of 1.7 years. 
Table 4.2 - Regional Regression Equation Peak Discharges (1.1 - 3 years). $Q(T)$ is the peak discharge in cfs for the specific year return period interval, $T$ is in years.

\begin{tabular}{lcccccc}
\hline Sub-basin identity: & NMTB1 & NMTB2 & NMTB3 & UBCB & NMTB4 & LBCB \\
\hline Drainage area $\left(\mathrm{mi}^{2}\right):$ & 0.327 & 0.426 & 0.918 & 1.425 & 1.971 & 22.176 \\
\hline$Q_{b k f}$ & 22 & 28 & 51 & 80 & 95 & 620 \\
\hline$Q(1.1)$ & 12.5 & 15.6 & 29.5 & 42.6 & 55.8 & 420.3 \\
$Q(1.2)$ & 14.9 & 18.6 & 35.3 & 50.9 & 66.8 & 504.0 \\
$Q(1.3)$ & 16.7 & 20.9 & 39.6 & 57.3 & 75.1 & 568.3 \\
$Q(1.4)$ & 18.2 & 22.8 & 43.3 & 62.5 & 82 & 622 \\
$Q(1.5)$ & 19.6 & 24.4 & 46.4 & 67.1 & 88.1 & 669.8 \\
$Q(1.6)$ & 20.8 & 25.9 & 49.3 & 71.3 & 93.6 & 711.4 \\
$Q(1.7)$ & 21.8 & 27.3 & 51.9 & 75.1 & 98.6 & 751.3 \\
$Q(1.8)$ & 22.9 & 28.5 & 54.3 & 78.6 & 103.2 & 786.3 \\
$Q(1.9)$ & 23.8 & 29.7 & 56.7 & 82.0 & 107.7 & 822.5 \\
$Q(2.0)$ & 24.4 & 30.5 & 58.2 & 84.3 & 110.8 & 850.7 \\
$Q(2.5)$ & 28.4 & 35.5 & 67.8 & 98.2 & 129.1 & 990.7 \\
$Q(3.0)$ & 31.2 & 39.1 & 74.6 & 108.1 & 142.1 & 1093.3 \\
\hline$S h a d i n g$ & & & & & & \\
\hline
\end{tabular}

Shading represents the range within which the bankfull discharge lies.

\subsubsection{HEC-HMS Analysis}

The regional regression analysis could not be applied to the 4 mineland tributaries as their drainage areas were below the range specified in Wiley et al. (2002). In order to find the find the return period for the peak discharge for these streams, HECHMS was used. The HEC-HMS program requires the following input.

- The basin model consisting of hydrologic parameters with sub-basin and reach input data, loss rate methods, transform options and baseflow functions.

- The rainfall depth and distribution, and

- The control specification including the time increment for the unit hydrograph.

The input data for the sub-basins included areas from the delineation of the Beaver Creek watershed. The watershed areas for the 4 mineland tributaries were delineated by importing into the Arc GIS program the $10 \mathrm{ft}$ contour maps developed by 
Baker Engineering. The valleys and ridges were carefully studied to accurately delineate the watershed area. The Arc GIS program automatically calculates the area inside a polygon with the help of the inbuilt raster calculator.

Curve Numbers for the sub-basins were generated by superimposing the landuse use / land cover map with the digitized soil survey map within the Arc GIS program. The area weighted composite Curve Numbers were generated using the SCS ARC II condition. The hydrologic watershed parameters such as the drainage area and the Curve Number for the Beaver Creek sub-basins are shown in Table 3.6

The SCS method of transformation was chosen within the HEC-HMS program in order to be consistent with the use of SCS methods. The lag time was required as an input parameter. As explained earlier, lag time is derived from the time of concentration, which in turn is estimated by the travel time of a water droplet from the most distant point in the sub-basin to the cross-section where the flow is to be computed. The time of concentration was determined by two methods:

- A - SCS equation using the Curve Number (Equation 38), and

- B - SCS divided flow section method (dividing the flow into sheet flow, shallow concentrated flow and channel flow (Equations 31, 32, 33/34, 35, 36 and 37)).

Table 4.3 lists the comparison for the time of concentration and lag time using the two methods.

The calculation of the time of concentration involves calculating the flow length for use in both the methods. The length of the channel reach may be wrongly estimated since many natural streams have considerable sinuosity as well as overfalls and eddies. Tendencies are therefore, to underestimate the length of the channel and to overestimate velocities through the reaches. The probability of underestimation of length increases as the drainage area increases. Hence the HEC-HMS program was used to estimate the peak discharge only for the 4 small sub-basins (mineland tributaries) for which regression equations do not apply. 

Table 4.3 - Time Of Concentration And Lag Time Using SCS Curve Number
Method (A) and SCS Divided Flow Section Method (B).

\begin{tabular}{ccccc}
\hline $\begin{array}{c}\text { Sub-basin } \\
\text { identity }\end{array}$ & \multicolumn{2}{c}{ Time of concentration (minutes) } & \multicolumn{2}{c}{ Lag time (minutes) } \\
\cline { 2 - 5 } & $\mathbf{A}$ & $\mathbf{B}$ & $\mathbf{( 0 . 6} \mathbf{x} \mathbf{A})$ & $\mathbf{( 0 . 6} \mathbf{x}$ B) \\
\hline MTB1 & 32 & 19 & 19 & 11 \\
MTB2 & 44 & 25 & 26 & 15 \\
MTB3 & 36 & 21 & 22 & 12 \\
MTB4 & 48 & 23 & 29 & 14 \\
NMTB1 & 105 & 35 & 63 & 21 \\
NMTB2 & 135 & 37 & 81 & 22 \\
NMTB3 & 99 & 54 & 59 & 33 \\
UBCB & 171 & 53 & 103 & 32 \\
NMTB4 & 250 & 60 & 150 & 36 \\
LBCB & 1758 & 468 & 1055 & 281 \\
\hline
\end{tabular}

A constant monthly baseflow method was chosen as an input parameter in the basin model. The constant monthly baseflow derived from the USGS gaging station (0306600) was shown previously in Table 3.5. The baseflow is very much less than the direct runoff peak flows, and hence this approximation is acceptable.

The basin model also requires a reach routing option, for which the Muskingum Cunge 8-point method was selected. The Muskingum Cunge 8-point method requires the 8-point cross-section of the reach along with the reach length, energy slope, and Manning's $n$ for the channel and the overbanks.

The cross-section survey done at the bankfull location was converted into the 8-point cross-section to be used in the routing method. For the 8-point cross-section configuration, 8 pairs of $x, y$ (distance, elevation) values are required. HEC (2003) suggests choosing the 8 pairs as follows:

- 2 pairs on the left overbank,

- 2 pairs on right overbank,

- 2 points on the main channel with one at thalweg, and 
- 2 points representing the bank stations.

Figure 4.7 shows a sample 8-point cross-section of MT4 used as an input in the Muskingum Cunge 8-point method along with all the surveyed points at that crosssection for comparison. The HEC-HMS program calculates the time step and distance steps from the reach cross-section data to calculate the routing coefficients.

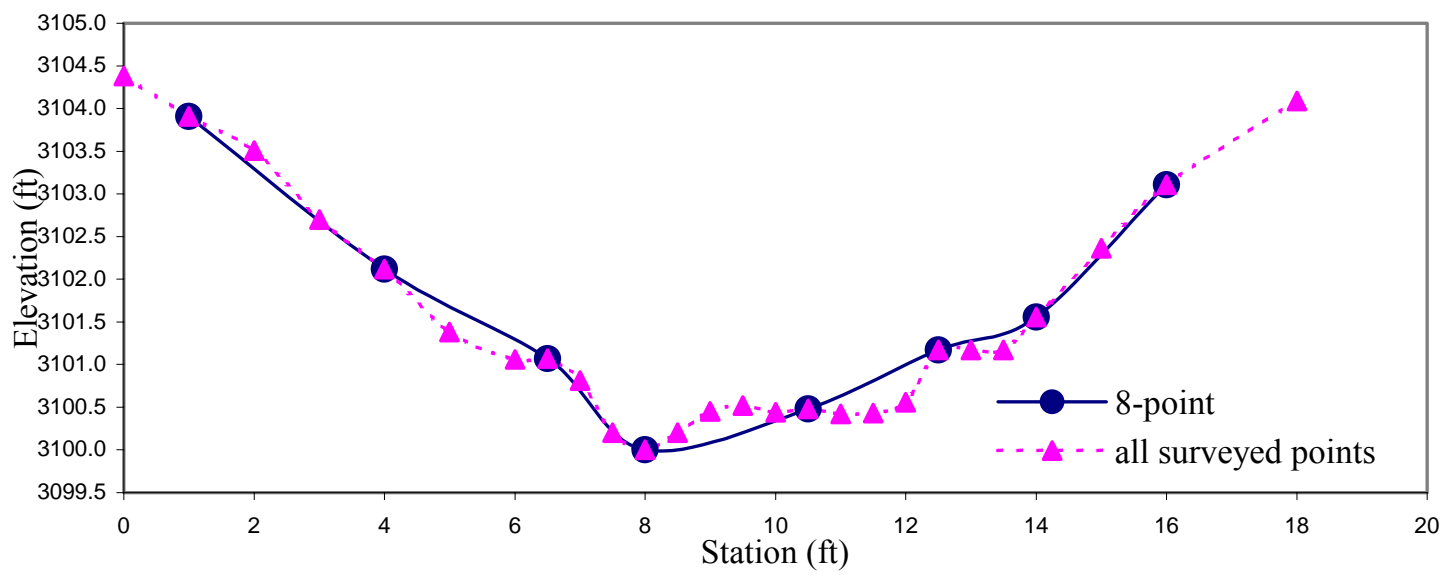

Figure 4.7 - 8-Point Cross-section For MT4.

The SCS hypothetical storm method was chosen for the meteorological specification within the HEC-HMS program. The design storm used in the program was SCS type II 24-hour rainfall distribution for return periods of 1, 2 and 5 years. The average 24-hour rainfall depths for the various return periods for the Beaver Creek watershed (Table 4.4) were obtained from the Rainfall Frequency Atlas of the United States (Hershfield 1961) and the West Virginia Erosion and Sediment Control Handbook for Developing Areas (USDA SCS, 1993). The Rainfall Frequency Atlas of the United States, popularly known as Technical Paper 40 (TP-40), is the most widely used atlas of precipitation extremes in the U.S.

Table 4.4 - TP-40 Average 24-Hour Precipitation For Various Return Periods.

\begin{tabular}{cc}
\hline $\begin{array}{c}\text { Return Period } \\
\text { (years) }\end{array}$ & $\begin{array}{c}\text { Rainfall depth } \\
\text { (inches) }\end{array}$ \\
\hline 1 & 2.39 \\
2 & 2.83 \\
5 & 3.62 \\
\hline
\end{tabular}


Having the basin model, meteorological model and the control specification set up in the HEC-HMS program, the peak discharges were evaluated for the 1,2 and 5 year return periods. Two separate analyses were done using the lag times derived from the equation (38) and the SCS divided flow method. Table 4.5 shows the peak discharges for the 4 mineland tributary watersheds for various return periods using the two different lag times.

Table 4.5 - Peak Discharges For Various Return Period Using HEC-HMS.

\begin{tabular}{|c|c|c|c|c|c|c|c|c|}
\hline \multirow{3}{*}{$\begin{array}{c}\text { Sub-basin } \\
\text { identity }\end{array}$} & \multirow{3}{*}{$\begin{array}{l}\text { Area } \\
\left(\mathbf{m i}^{2}\right)\end{array}$} & \multirow{3}{*}{$\begin{array}{c}\text { HEC-RAS } \\
\text { Bankfull } \\
\text { discharge } \\
\text { (cfs) }\end{array}$} & \multicolumn{6}{|c|}{ Peak discharges for various return periods (cfs } \\
\hline & & & \multicolumn{3}{|c|}{$\begin{array}{c}\text { Using SCS equation } \\
\text { (38) lag time }\end{array}$} & \multicolumn{3}{|c|}{$\begin{array}{c}\text { Using SCS divided } \\
\text { flow lag time }\end{array}$} \\
\hline & & & 1-yr & 2-yr & $5-y \mathbf{r}$ & 1-yr & $2-y \mathbf{r}$ & $5-y r$ \\
\hline MTBI & 0.040 & 13 & 13 & 19 & 31 & 18 & 27 & 43 \\
\hline MTB2 & 0.059 & 12 & 15 & 22 & 37 & 22 & 33 & 54 \\
\hline MTB3 & 0.059 & 13 & 14 & 22 & 37 & 21 & 32 & 55 \\
\hline MTB4 & 0.065 & 15 & 11 & 17 & 31 & 18 & 29 & 51 \\
\hline
\end{tabular}

The time of concentration calculation using the SCS equation (38) appears to give to be more realistic than the SCS divided flow method since the bankfull return period falls close to 1 year while using the SCS divided flow method gives bankfull discharges much less than one year. In reality, if bankfull observations are made in a stream, the chances of having a bankfull return interval of 1 year is more than having it at a return interval of around 0.5 years. Hence, calculating the time of concentration using SCS equation (38) is considered more appropriate in this study. The following results are based on SCS equation (38). Table 4.6 summarizes the return period of bankfull discharges for the various sub-basins in the Beaver Creek watershed used in this study. The return period for all the streams in the Beaver Creek watershed falls in the range 0.8 to 1.85 years and the average was computed to be 1.46 years. Figure 4.8 shows the return periods associated with drainage areas. 
Table 4.6 - Bankfull Discharge And Return Period For Various Sub-Basins.

\begin{tabular}{ccccc}
\hline $\begin{array}{c}\text { Sub-basin } \\
\text { identity }\end{array}$ & $\begin{array}{c}\text { Drainage area } \\
\text { (sq. miles) }\end{array}$ & $\begin{array}{c}\text { Bankfull } \\
\text { discharge (cfs) }\end{array}$ & $\begin{array}{c}\text { Return period } \\
\text { (years) }\end{array}$ & $\begin{array}{c}\text { Exceedence } \\
\text { probability } \\
\text { \% }\end{array}$ \\
\hline MTB1 & 0.040 & 13 & 1 & 100 \\
MTB2 & 0.059 & 12 & 0.8 & 125 \\
MTB3 & 0.059 & 13 & 1.2 & 83 \\
MTB4 & 0.065 & 15 & 1.7 & 59 \\
NMTB1 & 0.327 & 22 & 1.7 & 59 \\
NMTB2 & 0.426 & 28 & 1.75 & 57 \\
NMTB3 & 0.918 & 51 & 1.65 & 61 \\
UBCB & 1.425 & 80 & 1.85 & 54 \\
NMTB4 & 1.971 & 95 & 1.6 & 63 \\
LBCB & 22.176 & 620 & 1.4 & 71 \\
\hline
\end{tabular}

Probability is the inverse of the return period.

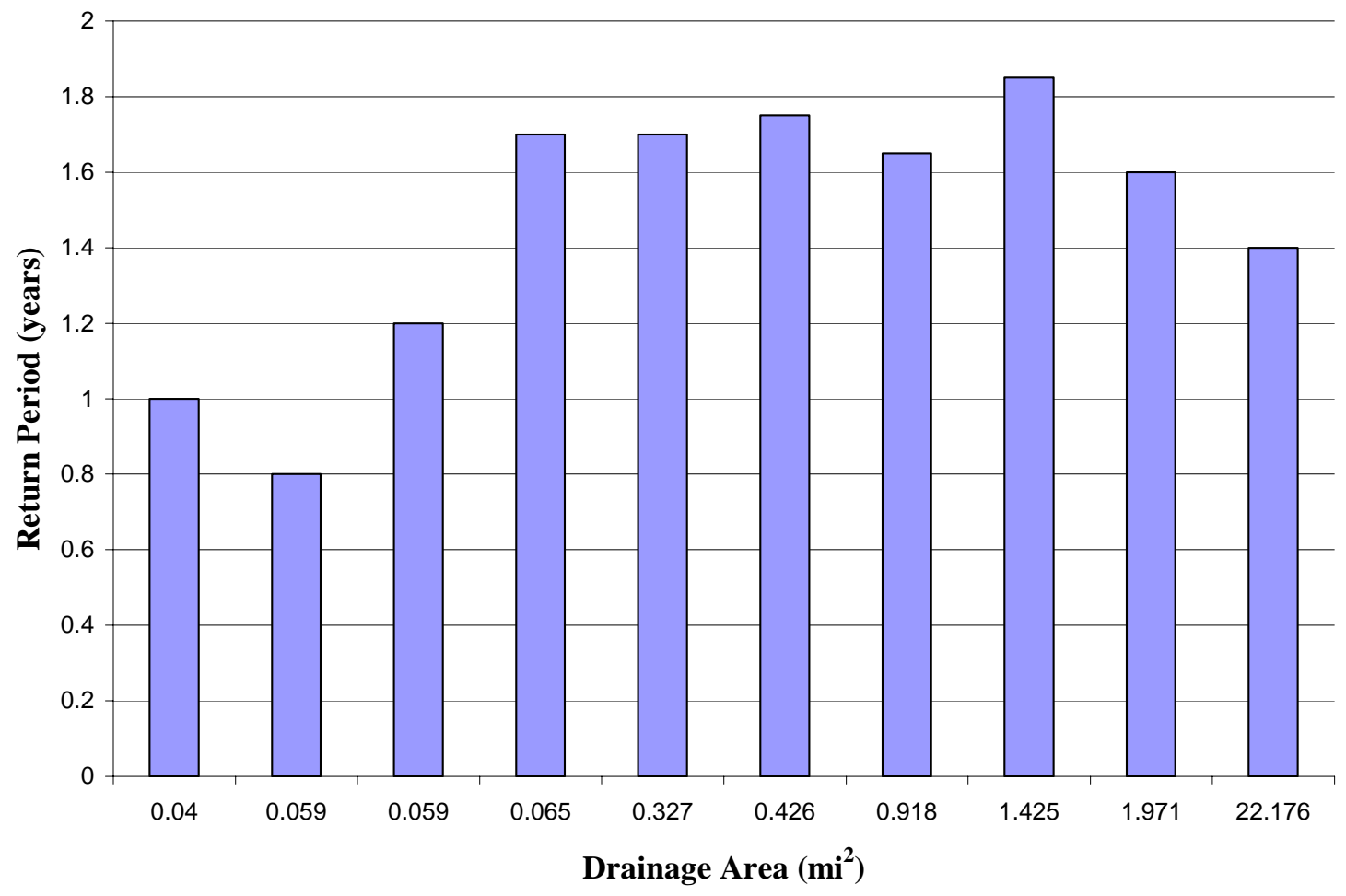

Figure 4.8 - Bankfull Return Period Versus Drainage Area. 


\section{CHAPTER 5 DISCUSSION AND CONCLUSION}

\subsection{Lateral Widening Of Mineland Tributaries}

Figures 4.3 - 4.6 present the family of regional geometry curves derived considering the mineland tributaries, non-mineland tributaries and Beaver Creek. However, the relationship between the drainage area and the bankfull width (Figure 5.1) shows much more scatter than the rest of the curves. The observed bankfull widths of the mineland tributaries are more than what is expected with the empirical power relationship given by Equation (42) i.e. the bankfull widths of the mineland streams seem to be underestimated by the power regression equation. Figure 5.1 shows an alternative regression equation for the bankfull width as a function of drainage area, excluding the data points of the mineland streams. Compare to Figure 4.5.

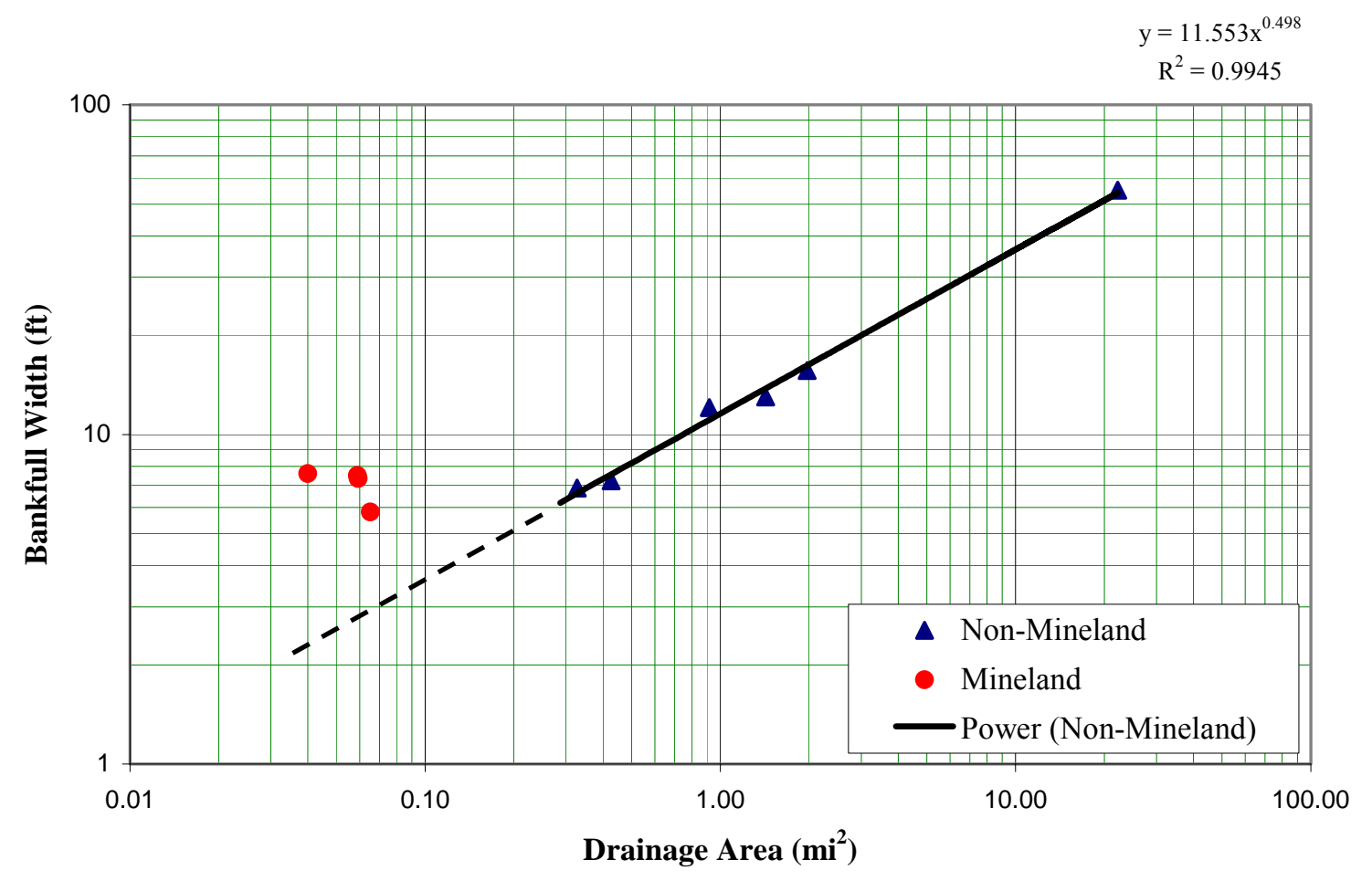

Figure 5.1 - Power Relationship For Bankfull Width To Drainage Area Excluding Mineland Streams. 
The new relationship (excluding the mineland tributaries) for bankfull width as a function of drainage area has a power function regression equation and corresponding coefficient of determination of:

$W_{b k f}=11.553 A_{d}^{0.498} \quad ;\left(\mathrm{R}^{2}=0.99\right)$

Equation (44) has a range of 0.33 to $22.18 \mathrm{mi}^{2}$. it should be compared to equation (42) which applies from 0.04 to $22.18 \mathrm{mi}^{2}$.

The application of this new power function regression equation to the mineland tributaries underestimates the observed bankfull widths from $80 \%$ to $196 \%$ with a mean of $140 \%$. A stream evolving on mineland spoils has more lateral expansion than a normal stream. This widening of the channel leads to lower velocities and hence slows movement of the bed load material. Even at the bankfull stage, such streams are less efficient and are unable to carry their bed load downstream. Hence such streams can be considered unstable for design and analysis purposes. Figure 5.2 shows a typical mineland stream with lateral expansion and a lot of deposited bed load material. The reach shown in the photograph lies upstream of the survey reach (MT2) used in this study. The section shown in the photograph did not have any bankfull indicator and showed very high lateral expansion.

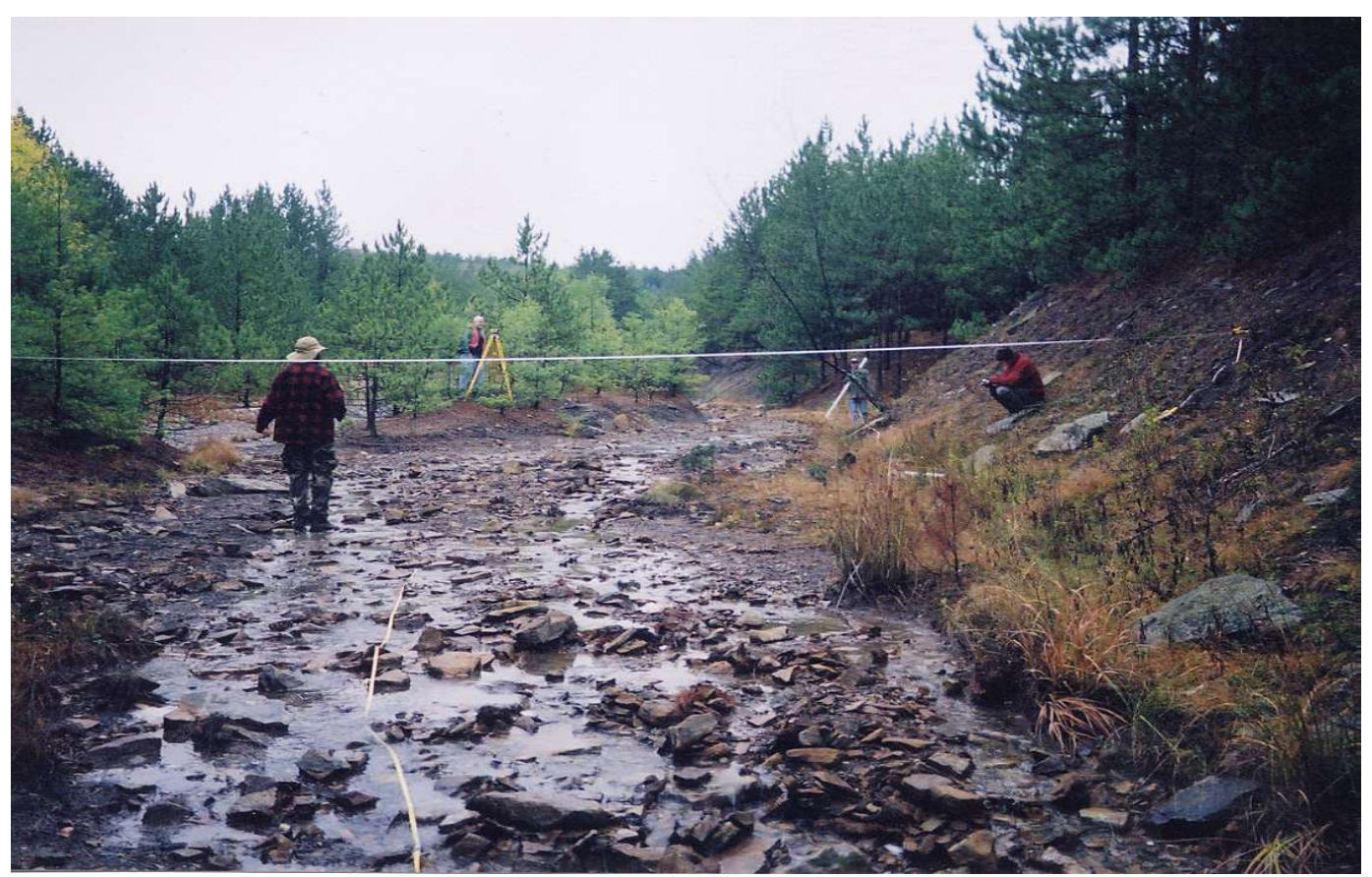

Figure 5.2 - Channel Photograph Showing Horizontal Widening And Bed Load Upstream of MT2 Looking Upstream. 
The results shown above are from preliminary investigations using numerical models. Users should regard the regional stream geometry curves with caution. These should be used only for reconnaissance-level studies. The range of application for these relationships is limited to the hydrographic province of the Beaver Creek watershed and to watersheds having area between $0.04 \mathrm{mi}^{2}$ (or $0.33 \mathrm{mi}^{2}$ ) and $22.18 \mathrm{mi}^{2}$. The hydraulic geometry relationships should be carefully applied to mineland tributaries as results suggest that these channels are not yet stabilized and will take more time to acquire a stable channel geometry relationship.

Separate analysis of the mineland streams was not possible as the study included only 4 mineland streams. This number of streams is not considered to be sufficient to carry out a regression analysis in this study. Beaver Creek watershed has a lot of streams evolving from mine spoils, but only few showed bankfull indicators. It is important to know that only streams showing bankfull indicators could be used in this study. Maybe with the passage of time, more mineland streams could be identified with bankfull indicators and some may show channel stability. The time frame for such adjustment cannot be predicted in this study.

\subsection{Verification Of Results}

The determination of bankfull discharge using HEC-RAS and the prediction of recurrence interval using regional regression equations and HEC-HMS is a method adopted due to unavailability of gaged data. Actual streamflow data is useful to develop local and regional curves of bankfull dimension / drainage area relations. The verification of results obtained by the use of numerical and hydrological models can be done in several ways.

Dunne and Leopold (1978) developed curves relating bankfull channel dimensions as a function of drainage area for four hydro-physiographic regions of United States. The power function regression equations (Equation 41-43) were plotted onto Dunne and Leopold's regional curves in Figure 5.3. It is seen that regression equations 


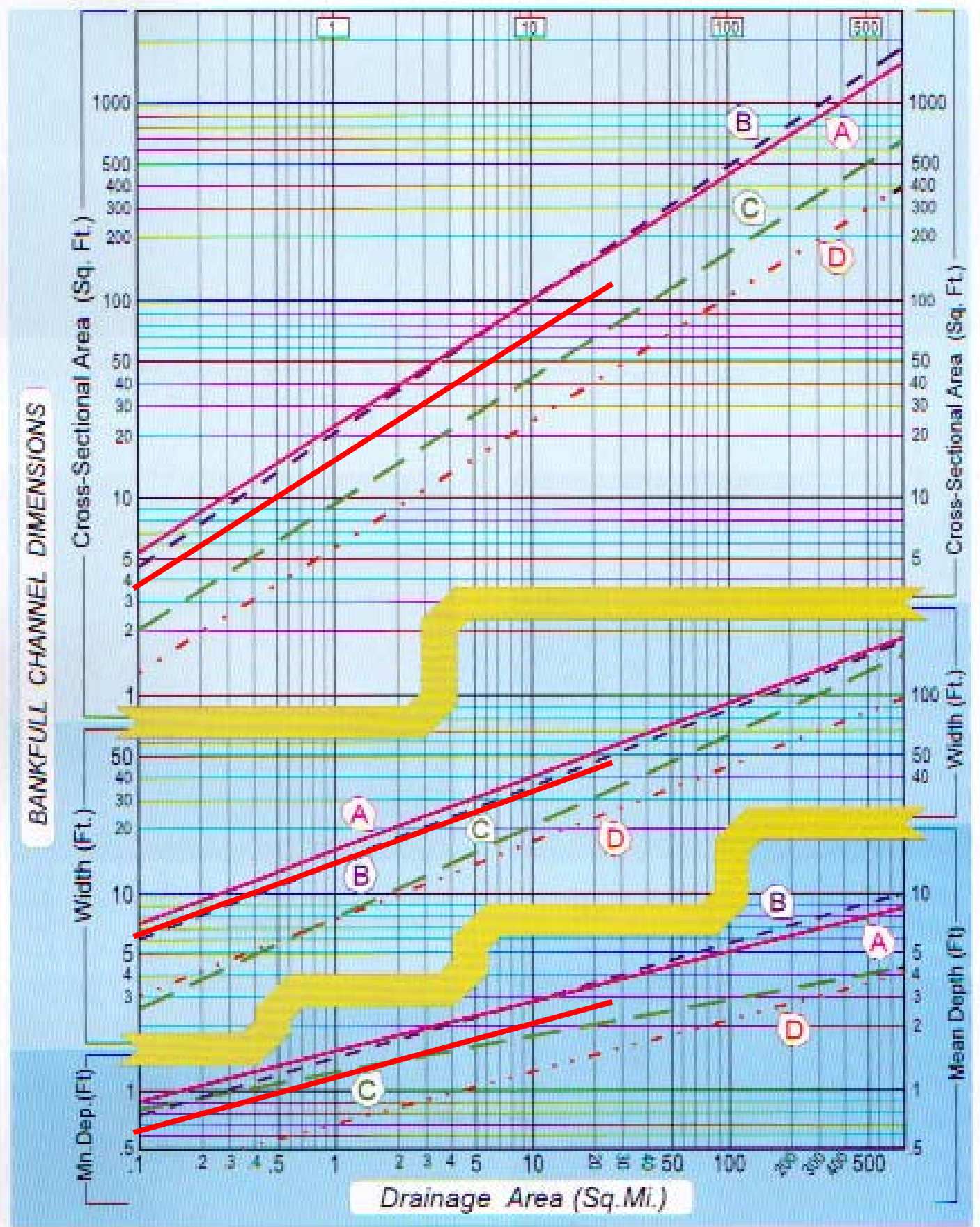
A: San Francisco Bay region
C: Upper Green River, Wyoming. at $30^{\prime \prime}$ annual precipitation.
B: Eastern United States
D: Upper Salmon River, Idaho. (Emmett 1975)

Figure 5.3 - Comparison Of Average Values Of Bankfull Channel Dimension As Functions Of Drainage Area.

(Bold red lines indicate the regional curves for Beaver Creek watershed) 
obtained for the Beaver Creek watershed (bold red line) lie close to the lines representing the Eastern United States (blue dashed line). Since bankfull hydraulic geometry relations vary by province, land cover, and rainfall/runoff relationship, a small degree of variability can be expected for the results obtained for the Beaver Creek watershed. The regression lines for the Beaver Creek watershed could not be plotted in full in Figure 5.3 as the range of drainage areas shown in the plot lies between $0.1 \mathrm{mi}^{2}$ and $800 \mathrm{mi}^{2}$. However, it can be inferred that the Beaver Creek regional curves for the study site match closely to the regional curves for the Eastern United States.

Gaged station analysis throughout the US has shown that the bankfull discharge has an average return interval of 1.5 years (Dunne and Leopold, 1978). The recurrence interval for bankfull flow was calculated using the bankfull discharge obtained by HEC-RAS, regional regression equations (Wiley et al., 2002) and HEC-HMS. The recurrence interval value for which the peak flow most closely matched the flow needed to fill the channel to the bankfull elevation as calculated using HEC-RAS was taken as the return period for bankfull flow events. The average return period obtained for this analysis was 1.46 years which is very close to the average return period of 1.5 years stated by Dunne and Leopold (1978). Hence, it can be said that the use of numerical and hydrological models is justified in the absence of gaged data.

\subsection{Morphological Factors Affecting Evolution Of Mineland Streams}

Streams develop in response to rainfall pattern, slope and length (topography), soils, geology, and vegetation. Surface mining drastically disturbs the land surface and geologic materials which help form the landscape. Strip mining of coal necessitates clearing of vegetative cover, removing soils above the coal seams, and then re-depositing it as spoil banks adjacent to the mine cuts. The reclamation procedure is designed to return disturbed areas to their approximate original contour by transporting, backfilling, compacting, and regrading spoils to eliminate all highwalls, spoil piles, and depressions. After grading, surfaces are covered with topsoil and re-vegetated. Until the surfaces are effectively re-vegetated, this method of reclamation can form, long steep slopes, which are subject to erosion ranging from rilling to severe gullying. 
Vegetation greatly aids in reducing erosion. Vegetation plays an important role in stabilizing channels that are adjusting due to human intervention and modification. Vegetation stabilizes channel banks by reducing near bank velocities and by increasing the cohesion of soils.

The formation of new channels on backfilled, unconsolidated material is difficult to predict due to the unknown character of the unconsolidated materials, their durability, cohesion, and particle size. The chemical constituents in such streams sometimes dissolve the unconsolidated materials while at other times result in precipitation and the formation of step-pools along the channel (as observed in MT1 and MT3). These changing characteristics make it more difficult for the stream to become stable over time. The lateral expansion along the width of the mineland streams MT2 and MT4 is a result of these factors that contribute to the unpredictable evolution on mineland spoils.

Designers for stream remediation and relocation on mineland spoils need to consider the factors that affect their evolution. Greater in-depth study is still needed for application of the regional curves knowing that these streams are not yet stabilized.

\subsection{State Of The Art Advancement Of Computer Models}

At present, very little information is available about the design and maintenance of 'natural' river restoration schemes, combining both hydraulic and morphological conditions. This combined field and numerical modeling study sought to address this situation by using two computer modeling tools: The 1-dimensional model HEC-RAS for predicting velocities and water depths longitudinally and the HEC-HMS model, which was applied to get the peak discharges for various return periods.

Modeling river systems using computers is a powerful tool in river engineering. The model can be subjected to various storm events, and the behavior of the stream studied. Where possible, the model should be verified from actual data from flow gaging stations (where available), and records of actual flooding events. Data are often sparse, however, and theoretical calculations of runoff into the rivers are limited in accuracy. Hydraulic modeling for rivers has only been generally available for practicing engineers in the recent years. It is increasingly common for modeling to be used to understand the behavior of rivers and to predict the consequences of change. Various studies have been relying on gaged data to develop families of regional stream geometry 
curves. The use of numerical and hydrological models in this study eliminated the use of gaged data and still got conclusive results. 


\subsection{Summary And Conclusion}

The main objective of the study was to develop a family of regional stream geometry curves for the hydrographic province of the Beaver Creek watershed and to estimate the return period of the bankfull discharges to aid in the stream restoration work. The datasets used for the analyses included 4 streams evolving on mine spoils, 4 natural tributaries to Beaver Creek, and 2 locations on Beaver Creek itself. Stream sites were evaluated by measuring the cross-sectional and longitudinal profile at riffle sections. Surveys were performed only on streams that had bankfull indicators. It was found that the most reliable bankfull stage indicators for the study streams were the topographic break (change in slope to horizontal) along the bank and the top of meander bend gravel bars.

The use of a numerical model (HEC-RAS) helped in predicting the flows at bankfull stages. The watershed hydrologic parameters such as the drainage area, basin slope, and Curve Number were estimated from the delineation of the sub-basin boundaries using the ESRI's Arc GIS software. Empirical equations and curves were generated that provided bankfull flow relationships (flowrate, cross-sectional area, width and depth) as a function of drainage area. The power function regression equations and corresponding coefficients of determination for 10 streams were:

$$
\begin{aligned}
& Q_{b l f}=65.476 A^{0.6057} ;\left(\mathrm{R}^{2}=0.96\right) \\
& A_{b k f}=15.586 A_{d}^{0.578} ;\left(\mathrm{R}^{2}=0.95\right) \\
& W_{b k f}=13.905 A_{d}^{0.2946} ;\left(\mathrm{R}^{2}=0.80\right) \\
& D_{b k f}=1.1209 A_{d}^{0.2836} ;\left(\mathrm{R}^{2}=0.94\right)
\end{aligned}
$$

These relationships are only applicable to the streams in the Beaver Creek watershed having drainage areas from $0.04 \mathrm{mi}^{2}$ to $22.18 \mathrm{mi}^{2}$. The empirical relationships were analyzed in detail to study the characteristics of the mineland streams. The streams evolving on mine spoils had widened channels, and the power regression equation underestimated the channel width for such streams by an average of approximately $140 \%$. Because they appeared to follow a different relationship for bankfull width, the 
regression analysis for bankfull width was repeated without the mineland streams. The revised regression equation for the bankfull depth as a function of drainage area for nonmineland streams is as follows:

$W_{b k f}=11.553 A_{d}^{0.498} ;\left(\mathrm{R}^{2}=0.99\right)$

This equation is valid for the non-mineland tributaries in the Beaver Creek watershed for drainage areas from $0.33 \mathrm{mi}^{2}$ to $22.18 \mathrm{mi}^{2}$.

Other characteristics of the mineland streams seem to blend with the rest of the datasets providing very high coefficients of determination. A large amount of sediment load along these streams also suggests that the mineland streams are not very efficient in transporting their bed load even at bankfull stages. Although they show bankfull indicators they may not yet have stabilized. Users must be careful to consider the application of these empirical relationships specific to mineland streams. Further work is necessary to develop reliable relationships for mineland streams with emphasis on their sediment load.

Determination of the bankfull recurrence interval for the Beaver Creek watershed was done with the help of regional regression equations for rural, unregulated streams in West Virginia (Wiley et al. 2002) and a hydrologic model (HEC-HMS). The estimate of the recurrence interval for the channel forming discharge (bankfull) was found to vary from 0.8 to 1.85 years with an average of 1.46 years. Gage station analysis throughout the United States has shown that the bankfull discharge has an average return interval of 1.5 years (Leopold, 1994), which is supported by the result of this study. 


\section{CHAPTER 6 SCOPE OF FURTHER RESEARCH}

While the work presented in this report suggests that relationships exist among streams in the study area, additional data analysis is needed to characterize the influence of channel types (Rosgen's classification) on channel properties. Other influencing features such as climate, soil, vegetation, topography, and geology could be considered for future study. Multiple linear regression analysis using one or more of the above mentioned characteristics in addition to the drainage area could be performed to get more reliable hydraulic geometry relationships.

The channel geometry analysis for this study was done using ungaged streams. Numerical and hydrologic models were used which do not require gaged stream data. However, gaged sites provide valuable flow information such as the rating curve (stage versus discharge), which could be helpful in verifying the bankfull flow. Since field determination of bankfull may be inaccurate, the gaged data could be used for accurate determination of bankfull flow values.

Field indicators and results from this study show that streams evolving on mine spoils have more lateral width, which leads to inefficiency in transporting their sediment load downstream. In natural stream channels, velocity and shear stress tend to equalize over pools and riffles at the bankfull discharge, which prevents them from becoming sediment laden. Hydraulic modeling at pool and riffle cross-sections would indicate the difference in the shear stress at bankfull discharges. This would determine whether stream has stabilized yet. It is desirable for many purposes to compute the transport rate of sediment from flow parameters. Sediment analysis and the development of a sediment rating curve would help in greater understanding of the geophysical process involved in mineland streams.

The use of the hydrologic model (HEC-HMS) involved the time of concentration as an input parameter. The time of concentration computed by empirical formulas shows a lot of variation. The use of field methods such as dye tracing would provide more accurate determination of time of concentration, allowing better results to be obtained from HEC-HMS. Similarly the length of the channel may be wrongly estimated since 
many natural streams have considerable sinuosity, meanders, overfall eddies, etc. that are overlooked on topographic maps. Field determination of channel length along the thalweg would eliminate the possible errors of underestimation of channel length.

Finally, the addition of more streams for the development of the hydraulic geometry curves would give more reliable relationships. If more bankfull features are observed on various streams of the Beaver Creek watershed, they could be used in building up the data set for the development of the regional curves. 


\section{REFERENCES}

Barnes, Harry H. Jr. (1967), 'Roughness Characteristics of Natural Channels.' USGS Water Supply Paper 1849.

Brookes A. and Shields F.D. (1996), 'Stream Channel Restoration: Guiding principles for Sustainable Projects'. John Wiley and Sons.

Chang H. (1998), 'Fluvial Processes in River Engineering'. Wiley-Interscience, New York.

Chow, V.T. (1959), ‘Open Channel Hydraulics’. McGraw-Hill, Inc., New York.

Dunne, T. and Leopold, L. B. (1978) 'Water in Environmental Planning.' Freeman, San Francisco, CA

Dury, G.H. (1973), 'Magnitude-Frequency Analysis and Channel Morphology.' In Fluvial Geomorphology, ed. M. Morisaua, pp. 91-121. Allen \& Unwin.

Emmett, W.M. (1975), 'The Channels and Waters of the Upper Salmon River Area.' Idaho. USGS Professional Paper 870-A, Washington, D.C.

Fetter, C. W. (1994), 'Applied Hydrogeology.’ Third Edition. Prentice-Hall, Inc., NJ.

Hawkins, R. H., Jiang, R., Woodward, D. E., Hjelmfelt, Jr., A. T., VanMullem, J. A. (2002), 'Runoff Curve Number Method: Examination of the Initial Abstraction Ratio.' Master's Thesis by Ruiyun Jiang, University of Arizona.

HEC (2002), 'River Analysis System HEC-RAS Version 3.1': Technical reference manual. Hydrologic Engineering Center, USACE, Davis, CA.

HEC (2002), 'River Analysis System HEC-RAS Version 3.1': Users manual. Hydrologic Engineering Center, USACE, Davis, CA.

HEC (2003), 'Hydrologic Modeling System HEC-HMS Version 2.2.2': Technical reference manual. Hydrologic Engineering Center, USACE, Davis, CA.

HEC (2003), 'Hydrologic Modeling System HEC-HMS Version 2.2.2': Users manual. Hydrologic Engineering Center, USACE, Davis, CA.

Hershfield, David M. (1961). 'Rainfall Frequency Atlas for United States for Durations from 30 minutes to 24 hours and Return Periods from 1 to 100 years.' Weather Bureau Technical Paper 40, US Department of Commerce, Washington, D.C. 155p. 
Hey, R.D. (1975), 'Design Discharge for Natural Channels in Science, Technology and Environmental Management', ed. R.D. Hey and T.D. Davies, pp. 73- 88. Saxxon House, Farnborough.

Hey R.D. (1998), 'Frequency and Duration of Bankfull Flow and application for Natural Channel Design.' In Hayes D.F. (ed) Engineering Approaches to Ecosystem Restoration: Proceedings of the 1998 Wetlands Engineering and River Restoration Conference, Denver, 1998, American Society of Civil Engineers, Reston, VA.

Hicks, D. M. and Mason, P.D. (1998) 'Roughness Characteristics of New Zealand Rivers.' A handbook for assigning hydraulic roughness coefficients to river reaches by the visual comparison approach, Water Resources Publication, LLC.

Hudnall, P. F. (2003), 'Characterization and Recommendations for the Remediation of Acid Mine Drainage Impacted Streams', Thesis Work, Dept of Civil and Environmental Engineering, West Virginia University.

Kent, Kenneth M. (1972), 'Travel time, Time of concentration, and Lag.' Part 630 Hydrology, Section 4, National Engineering Handbook, USDA SCS, Washington D.C.

Leopold, L.B., and T. Maddock, Jr. (1953), 'The Hydraulic Geometry of Stream Channels and Some Physiographic Implications.' Geological Survey Professional Paper 252. U.S. Geological Survey, Washington, DC.

Leopold, L.B., (1994), 'A View of the River.' Harvard University Press, Cambridge, Massachusetts.

Leopold, L. B., Wolman, M. G. and Miller, J. P. (1964), 'Fluvial Processes in Geomorphology.' Freeman, San Fransisco, CA

McCuen, Richard (1998), 'Hydrologic Analysis and Design.' Prentice Hall, Inc. Upper Saddle River, NJ.

Pickup, G. and Warner, R.F. (1976), 'Effects of Hydrologic Regime on Magnitude and Frequency of Dominant Discharge.’ Journal of Hydrology 29 (1): 51-75.

Ponce, V. M. (1986), 'Diffusion Wave Modeling of Catchment Dynamics.' Journal of Hydraulics Division, ASCE, 112(8), 716-727.

Ponce, Victor M., Hawkins, Richard H. (1996), 'Runoff Curve Number: Has It Reached Maturity?” Journal of Hydrologic Engineering, ASCE, 1(1), 11-19.

Richards, K.S. (1982), 'Rivers: Form and Process in Alluvial Channels.' Methuen, London. 
Rosgen D. (1996), 'Applied River Morphology.' Printed media companies, Minneapolis, Minnesota.

Runner, G.S. (1980), 'Runoff Studies on Small Drainage Areas (Technique for estimating magnitude and frequency of floods in West Virginia).' West Virginia Department of Highways Research Project 16: U.S. Geological Survey Open-File Report 80- 560, 169 p.

Sawada, M., Computer program 'HydroSep Beta 1.5'. University of Ottawa, Canada.

http://www.uottawa.ca/academic/arts/geographie/lpcweb/newlook/data_and_downloads/d ownload/sawsoft/hydrosep.htm

Tummala V. (2003), 'Hydrology of the Beaver Creek Watershed Using the TR-20 model and the HEC-HMS Program.' Thesis Work, Dept of Civil and Environmental Engineering, West Virginia University.

USDA, NRCS (2001), 'Stream Corridor Restoration: Principles, Processes, and Practices.' By the Federal Interagency Stream Restoration Working Group.

USDA, SCS (1985), 'Part 630 - Hydrology, Section 4, National Engineering Handbook.' USDA SCS, Washington, D.C.

USDA, SCS (1993), 'Handbook for Developing Areas Erosion and Sediment Control, WV.' USDA, SCS, Morgantown, WV.

Viessman W. and Lewis G. (2003), 'Introduction to Hydrology.' $5^{\text {th }}$ Edition, Prentice Hall, Upper Saddle River, NJ.

Wiley, Jeffrey B., Atkins, Jr., John T., and Tasker, Gary D. (2000), 'Estimating Magnitude and Frequency of Peak Discharges for Rural, Unregulated, Streams in West Virginia.' US Geological Survey Water Resources-Investigations Report 00-4080, 93p.

Wiley, Jeffrey B., Atkins, Jr., John T., and Newell, Dawn A. (2002), 'Estimating Magnitude of Annual Peak Discharges with Recurrence Intervals between 1.1 and 3.0 Years for Rural, Unregulated, Streams in West Virginia.' US Geological Survey Water Resources-Investigations Report 02-4164, 73p.

Wilks, D.S. and R.P. Cember, (1993), 'Atlas of Precipitation Extremes for the Northeastern United States and Southeastern Canada.' Northeast Regional Climate Center Research Publication No. RR 93-5, 40 pp.

Williams, G.W. (1978), 'Bankfull Discharge of Rivers'. Water Resources Research 14: 1141-1154.

Wolman, M.G. and L. B. Leopold. (1957). 'River Flood Plains: Some Observations on Their Formation.' USGS Professional Paper 282C. 


\title{
GLOSSARY
}

\author{
ARC - Antecedent Runoff Condition \\ AMD - Acid Mine Drainage \\ BYU - Brigham Young University \\ CEE - Civil and Environmental Engineering, Department of \\ $\mathrm{CN} \quad-$ Curve Number \\ DEM - Digital Elevation Model \\ EMRL - Environmental Modeling Research Laboratory \\ ESRI - Environmental Systems Research Institute \\ FHA - Federal Highway Administration \\ FEMA - Federal Emergency Management Agency \\ GIS - Geographic Information Systems \\ GPS - Global Positioning System \\ GUI - Graphical User interface \\ HEC - Hydrologic Engineering Center \\ HEC-2 - Hydrologic Engineering Center-2 model \\ HEC-HMS - Hydrologic Engineering Center Hydrologic Modeling System \\ HEC-RAS - Hydrologic Engineering Center River Analysis System \\ IWR - Institute of Water Resources \\ NEH - National Engineering Handbook \\ NFF - National Flood Frequency \\ NRAC - Natural Resource Analysis Center \\ NRCS - Natural Resources Conservation Service (formerly known as SCS) \\ NWS - National Weather Service \\ SCS - Soil Conservation Service \\ UH - Unit Hydrograph \\ US - United States \\ USACE - United States Army Corps of Engineers \\ USDA - United States Department of Agriculture \\ USGS - United States Geological Survey
}



WV - West Virginia
WVDEP - West Virginia Department of Environmental Protection
WVDOH - West Virginia Division of Highways
WVU - West Virginia University 


\section{APPENDIX A}


Table A-1 - Hydraulic Characteristics Of MT1 Obtained From HEC-RAS.

\begin{tabular}{lrrrrr}
\hline & \multicolumn{5}{c}{ Cross-sectional information } \\
\cline { 2 - 5 } Station Identity.: & 70 & 58.2 & 40.2 & 20.1 \\
Reach Length to next d/s x-section (ft): & 11.8 & 18.0 & 20.1 & 13.0 \\
Area (sq ft): & 3.22 & 3.5 & 3.04 & 5.96 & 2.57 \\
Flow (cfs): & 13 & 13 & 13 & 13 & 13 \\
Top Width (ft): & 8.15 & 7.61 & 6.49 & 10.22 & 5.87 \\
Depth (ft): & 0.40 & 0.46 & 0.47 & 0.58 & 0.44 \\
Avg. Velocity (ft/s): & 4.13 & 4.46 & 4.44 & 2.87 & 5.28 \\
Hydraulic Depth (ft): & 1.06 & 1.07 & 0.85 & 1.3 & 0.83 \\
\hline
\end{tabular}

Table A-2 - Hydraulic Characteristics Of MT2 Obtained From HEC-RAS.

\begin{tabular}{lrrrrr}
\hline & \multicolumn{5}{c}{ Cross-sectional information } \\
Station Identity: & 88 & 66.3 & 45.8 & 27.7 & 14.5 \\
Reach Length. to next d/s x-section (ft): & 21.7 & 20.5 & 18.1 & 13.2 \\
Area (sq ft): & 3.44 & 3.54 & 3.2 & 3.97 & 3.97 \\
Flow (cfs): & 12 & 12 & 12 & 12 & 12 \\
Top Width (ft): & 6.61 & 9.93 & 7.51 & 6.72 & 9.19 \\
Depth (ft): & 0.52 & 0.36 & 0.43 & 0.59 & 0.43 \\
Avg. Velocity (ft/s): & 3.71 & 3.64 & 3.75 & 3.02 & 3.17 \\
Hydraulic Depth (ft): & 0.6 & 0.49 & 0.43 & 0.59 & 0.62 \\
\hline
\end{tabular}


Table A-3 - Hydraulic Characteristics Of MT3 Obtained From HEC-RAS.

\begin{tabular}{lrrrrr}
\hline & \multicolumn{5}{c}{ Cross-sectional information } \\
\cline { 2 - 6 } Station Identity.: & 91 & 68.4 & 49.5 & 27 & 5 \\
Reach Length to next d/s x-section (ft): & 22.6 & 18.9 & 22.5 & 22 & 3.7 \\
Area (sq ft): & 3.99 & 4.31 & 3.84 & 3.29 & 13 \\
Flow (cfs): & 13 & 13 & 13 & 13 \\
Top Width (ft): & 13.32 & 11.53 & 9.87 & 7.34 & 7.2 \\
Depth (ft): & 0.98 & 1.13 & 1.32 & 1.77 & 1.81 \\
Avg. Velocity (ft/s): & 3.43 & 3.98 & 4.77 & 3.95 & 4.23 \\
Hydraulic Depth (ft): & 0.37 & 0.66 & 0.8 & 0.49 & 0.53 \\
\hline
\end{tabular}

Table A-4 - Hydraulic Characteristics Of MT4 Obtained From HEC-RAS.

\begin{tabular}{lrrrrr}
\hline & \multicolumn{4}{c}{ Cross-sectional information } \\
\cline { 2 - 5 } Station Identity: & 94 & 71 & 57 & 46 & 33 \\
Reach Length. to next d/s x-section (ft): & 23 & 14 & 11 & 13 & 3.4 \\
Area (sq ft): & 3.46 & 4.25 & 3.39 & 15.44 \\
Flow (cfs): & 15 & 15 & 15 & 15 \\
Top Width (ft): & 6.04 & 6.34 & 5.85 & 5.82 & 6.07 \\
Depth (ft): & 0.57 & 0.67 & 0.58 & 0.58 & 0.57 \\
Avg. Velocity (ft/s): & 4.34 & 3.53 & 4.45 & 4.41 & 4.36 \\
Hydraulic Depth (ft): & 0.57 & 0.67 & 0.62 & 0.58 & 0.57 \\
\hline
\end{tabular}


Table A-5 - Hydraulic Characteristics Of NMT1 Obtained From HEC-RAS.

\begin{tabular}{lrrrrr}
\hline & \multicolumn{4}{c}{ Cross-sectional information } \\
\cline { 2 - 6 } Station Identity.: & 96 & 82 & 49 & 28 & 5 \\
Reach Length to next d/s x-section (ft): & 14 & 33 & 21 & 23 & 4.24 \\
Area (sq ft): & 6.65 & 5.67 & 5.38 & 22 \\
Flow (cfs): & 22 & 22 & 22 & 22 \\
Top Width (ft): & 10.25 & 8.18 & 6.88 & 4.84 & 5.32 \\
Depth (ft): & 0.65 & 0.69 & 0.78 & 0.88 & 0.82 \\
Avg. Velocity (ft/s): & 3.32 & 3.89 & 4.1 & 5.19 & 5.21 \\
Hydraulic Depth (ft): & 0.73 & 0.69 & 0.9 & 0.88 & 0.85 \\
\hline
\end{tabular}

Table A-6 - Hydraulic Characteristics Of NMT2 Obtained From HEC-RAS.

\begin{tabular}{|c|c|c|c|c|c|}
\hline \multirow[b]{2}{*}{ Station Identity: } & \multicolumn{5}{|c|}{ Cross-sectional information } \\
\hline & 89 & 58 & 38 & 24 & 12 \\
\hline Reach Length. to next d/s x-section (ft): & 31 & 20 & 14 & 12 & \\
\hline Area (sq ft): & 5.45 & 5.53 & 7.39 & 7.21 & 6.88 \\
\hline Flow (cfs): & 28 & 28 & 28 & 28 & 28 \\
\hline Top Width (ft): & 5.82 & 7.22 & 5.89 & 7.3 & 5.8 \\
\hline Depth (ft): & 0.94 & 0.77 & 1.25 & 0.99 & 1.19 \\
\hline Avg. Velocity (ft/s): & 5.23 & 5.08 & 3.79 & 4.8 & 4.7 \\
\hline Hydraulic Depth (ft): & 1.02 & 0.81 & 1.25 & 1.3 & 1.04 \\
\hline
\end{tabular}


Table A-7 - Hydraulic Characteristics Of NMT3 Obtained From HEC-RAS.

\begin{tabular}{|c|c|c|c|c|c|}
\hline \multirow[b]{2}{*}{ Station Identity.: } & \multicolumn{5}{|c|}{ Cross-sectional information } \\
\hline & 96 & 75 & 42 & 29 & 5 \\
\hline Reach Length to next $d$ /s $x$-section (ft): & 21 & 33 & 13 & 24 & \\
\hline Area (sq ft): & 12.93 & 13.36 & 16.08 & 9.21 & 8.91 \\
\hline Flow (cfs): & 51 & 51 & 51 & 51 & 51 \\
\hline Top Width (ft): & 21.21 & 13.31 & 12.04 & 9.93 & 10.2 \\
\hline Depth (ft): & 0.61 & 1.00 & 1.34 & 0.93 & 0.87 \\
\hline Avg. Velocity (ft/s): & 4.54 & 3.87 & 3.22 & 5.53 & 4.95 \\
\hline Hydraulic Depth (ft): & 0.97 & 1.14 & 1.75 & 0.93 & 1.12 \\
\hline
\end{tabular}

Table A-8 - Hydraulic Characteristics Of UBC Obtained From HEC-RAS.

\begin{tabular}{|c|c|c|c|c|c|}
\hline \multirow[b]{2}{*}{ Station Identity: } & \multicolumn{5}{|c|}{ Cross-sectional information } \\
\hline & 104 & 85.1 & 57 & 34 & 15 \\
\hline Reach Length. to next $d / s$-section (ft): & 18.9 & 27.1 & 22 & 19 & \\
\hline Area (sq ft): & 14.85 & 14.85 & 15.77 & 13.21 & 13.76 \\
\hline Flow (cfs): & 80 & 80 & 80 & 80 & 80 \\
\hline Top Width (ft): & 12.49 & 15.14 & 12.71 & 12.98 & 13.37 \\
\hline Depth (ft): & 1.19 & 0.98 & 1.24 & 1.02 & 1.03 \\
\hline Avg. Velocity (ft/s): & 5.46 & 5.29 & 5.05 & 6.04 & 5.81 \\
\hline Hydraulic Depth (ft): & 1.32 & 1.29 & 1.83 & 1.17 & 1.03 \\
\hline
\end{tabular}


Table A-9 - Hydraulic Characteristics Of NMT4 Obtained From HEC-RAS.

\begin{tabular}{lrrrr}
\hline & \multicolumn{3}{c}{ Cross-sectional information } \\
Station Identity.: & 70 & 45 & 22 \\
Reach Length to next d/s x-section (ft): & 25 & 23 & 18 & 4 \\
Area (sq ft): & 24.19 & 23.58 & 14.91 & 15.71 \\
Flow (cfs): & 95 & 95 & 95 & 95 \\
Top Width (ft): & 13.49 & 15.62 & 9.19 & 8.91 \\
Depth (ft): & 1.79 & 1.51 & 1.62 & 1.76 \\
Avg. Velocity (ft/s): & 3.93 & 4.08 & 6.37 & 6.5 \\
Hydraulic Depth (ft): & 1.79 & 2.02 & 1.62 & 1.59 \\
\hline
\end{tabular}

Table A-10 - Hydraulic Characteristics Of LBC Obtained From HEC-RAS.

\begin{tabular}{|c|c|c|c|c|c|}
\hline \multirow[b]{2}{*}{ Station Identity: } & \multicolumn{5}{|c|}{ Cross-sectional information } \\
\hline & 140 & 98 & 72 & 39 & 8 \\
\hline Reach Length. to next d/s x-section (ft): & 42 & 26 & 33 & 31 & \\
\hline Area (sq ft): & 163.25 & 161.04 & 102.2 & 135.29 & 125.53 \\
\hline Flow (cfs): & 620 & 620 & 620 & 620 & 620 \\
\hline Top Width (ft): & 65.75 & 53.18 & 45.42 & 55.08 & 58.4 \\
\hline Depth (ft): & 2.48 & 3.03 & 2.25 & 2.46 & 2.15 \\
\hline Avg. Velocity (ft/s): & 3.96 & 3.94 & 6.33 & 4.66 & 5.93 \\
\hline Hydraulic Depth (ft): & 3.18 & 3.36 & 3.11 & 3.02 & 3.23 \\
\hline
\end{tabular}

